\title{
Hydrology of the
}

Ferron Sandstone Aquifer and

Effects of Proposed

Surface-Coal Mining in

Castle Valley, Utah

By Gregory C. Lines and Daniel J. Morrissey

With a section on STRATIGRAPHY

By Thomas A. Ryer

And a section on LEACHING OF OVERBURDEN

By Richard H. Fuller

Prepared in cooperation

with the U.S. Bureau of

Land Management 


\title{
UNITED STATES DEPARTMENT OF THE INTERIOR
}

\author{
JAMES G. WATT, Secretary \\ GEOLOGICAL SURVEY \\ Dallas L. Peck, Director
}

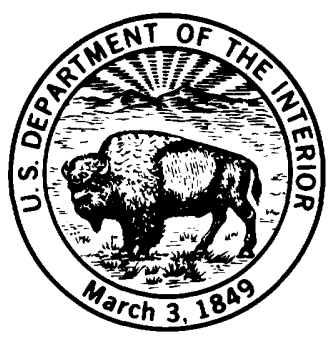

For sale by the Branch of Distribution

U.S. Geological Survey

604 South Pickett Street

Alexandria, VA 22304

Library of Congress Cataloging in Publication Data

Lines, Gregory C.

Hydrology of the Ferron sandtone aquifer and effects of proposed surface-coal mining in Castle Valley, Utah.

(Geological Survey water-supply paper 2195)

"Prepared in cooperation with the U.S. Bureau of Land Management."

Bibliography $40 \mathrm{p}$.

Supt. of Docs. No.: I 19.13:2195

1. Waters, Underground-Utah-Castle Valley. 2. Coal mines and mining-Environmental aspects-Utah-Castle Valley. 3. Strip mining-Environmental aspects-UtahCastle Valley. I. Morrissey, Daniel J. II. United States. Bureau of Land Management. III. Title. IV. Series. 


\section{CONTENTS}

Abstract 1

Introduction $\mathbf{2}$

Problem and objectives $\mathbf{2}$

Methods of investigation $\mathbf{3}$

Previous investigations $\mathbf{3}$

Acknowledgments $\mathbf{3}$

Well-, spring-, and site-numbering system 4

Stratigraphy, by Thomas A. Ryer 4

Ferron sandstone aquifer $\mathbf{6}$

Aquifer characteristics $\mathbf{6}$

Thickness 6

Hydraulic conductivity $\mathbf{8}$

Transmissivity $\mathbf{8}$

Storage $\mathbf{8}$

Potentiometric surfaces $\mathbf{1 1}$

Basal section 11

Upper section $\mathbf{1 1}$

Adjacent water-bearing zones

12

Water-level changes 14

Movement and age of water 15

Recharge and discharge $\mathbf{1 6}$

Subsurface inflow $\mathbf{1 7}$

Precipitation on outcrop area

Leakage 17

Transpiration of phreatophytes

Springs and seeps 18

Well discharges 18

Mine dewatering 19

Availability of water 19

Quality of water 19

Surface water $\mathbf{2 2}$

Quantity 22

Quality 22

Inorganic dissolved solids $\mathbf{2 2}$

Suspended sediment 24

Benthic invertebrates $\mathbf{2 5}$

Computer model $\mathbf{2 6}$

Assumptions and accuracy 27

Prediction 27

Effects of proposed surface mining

Mining plans $\mathbf{2 8}$

Mine dewatering $\mathbf{2 8}$

Effects on ground water $\mathbf{2 8}$

Effects on surface water $\mathbf{2 9}$

Leaching of overburden, by Richard H. Fuller 29

Erosion of overburden $\mathbf{3 0}$

Need for future study $\mathbf{3 2}$

Summary $\mathbf{3 2}$

References cited $\mathbf{3 2}$ 


\section{PLATES (In pocket)}

1. Map showing location of selected wells, springs, and test holes in and near Castle Valley, Utah, where ground-water information is available, 1980.

2. Map showing the thickness of the Ferron Sandstone Member of the Mancos Shale in Castle Valley, Utah.

3. Map showing the altitude of the top of the Ferron Sandstone Member of the Mancos Shale in Castle Valley, Utah.

\section{FIGURES}

1. Map of Utah showing the study area 2

2. Diagram showing the well-. spring-, and site-numbering system used in Utah $\mathbf{5}$

3. Photograph showing the outcrop of the Ferron Sandstone Member of the Mancos Shale along Quitchupah Creek near Emery 6

4. Photograph showing the outcrop of the Washboard unit of Cotter (1975a) of the Ferron Sandstone Member of the Mancos Shale along U.S. Highway 6 southeast of Wellington 6

5. Diagrammatic southwest-northeast section showing stratigraphic relationships of the various units of the Ferron Sandstone Member and the Tununk and Blue Gate Members of the Mancos Shale in Castle Valley 6

6-10. Maps of the Emery area showing:

6. Geology 7

7. Transmissivity of the Ferron sandstone aquifer $\mathbf{1 0}$

8. Potentiometric surface of the basal section of the Ferron sandstone aquifer, $1979 \mathbf{1 2}$

9. Potentiometric surface of the upper section of the Ferron sandstone aquifer, 197913

10. Configuration of the water table in rocks that overlie the Ferron sandstone aquifer, $1979 \quad 14$

11. Hydrographs showing water-level changes in four wells that tap the Ferron sandstone aquifer in the Emery area 15

12. Diagrammatic section showing sources of recharge to and discharge from the Ferron sandstone aquifer in the Emery area, $1979 \quad 16$

13. Photograph showing salt on the barren shale slopes of the Tununk Member of the Mancos Shale where ground water has evaporated 18

14-16. Maps of the Emery area showing:

14. Concentration of dissolved solids in water in the basal section of the Ferron sandstone aquifer, $1979 \mathbf{2 0}$

15. Concentration of dissolved solids in water in the upper section of the Ferron sandstone aquifer, $1979 \quad 21$

16. Location of data-collection sites on Quitchupah Creek and Christiansen Wash, 1978-79 23

17-19. Graphs showing:

17. Monthly variation in the concentration and load of dissolved solids at gaging stations 09331900 and 09331950 on Quitchupah Creek and Christiansen Wash in the Emery area, water year $1979 \mathbf{2 4}$

18. Relationship between suspended-sediment concentration and stream discharge at gaging station 09331900 on Quitchupah Creek in the Emery area, August 1978-September $1979 \mathbf{2 5}$

19. Relationship between suspended-sediment concentration and stream discharge at gaging station 09331950 on Christiansen Wash in the Emery area, May 1978-September $1979 \mathbf{2 5}$ 


\section{FIGURES}

20. Map of the Emery area showing the variable grid used in the three-dimensional digital-computer model and the predicted drawdown of the potentiometric surface of the upper section of the Ferron sandstone aquifer around the proposed surface mine after 15 years of operation 26

21. Photograph showing area of proposed surface mine along Christiansen Wash 28

22. Photograph showing sparsely vegetated surface of the Blue Gate Member of the Mancos Shale that is typical of area where proposed surface mining will terminate $\mathbf{2 8}$

\section{TABLES}

1. Laboratory determinations of porosity, hydraulic conductivity, and grain size of rock samples from the Ferron Sandstone Member of the Mancos Shale 9

2. Summary of aquifer tests conducted on the Ferron sandstone aquifer in the Emery area, 1978-79 9

3. Description of samples from the Ferron Sandstone and Blue Gate Members of the Mancos Shale that were used in equilibration experiments $\mathbf{3 0}$

4. Chemical analyses of leachate after equilibration with typical spoil material from the Ferron Sandstone and Blue Gate Members of the Mancos Shale 31

5. Records of selected wells, test holes, and springs in the Castle Valley area $\mathbf{3 4}$

6. Chemical analyses of water from wells, test holes, springs, and the Emery Mine 38

7. Benthic invertebrates collected from Christiansen Wash and Quitchupah Creek in the Emery area, 1978-79 40 


\section{Conversion Factors}

Most numbers are given in this report in inch-pound units. For those readers who may prefer to use metric units, the conversion factors for the terms used in this report are listed below. Multiply the inch-pound unit by the factor to obtain the metric equivalent.

\begin{tabular}{|c|c|c|c|}
\hline \multicolumn{2}{|c|}{ Inch-pound } & \multicolumn{2}{|c|}{ Metric unit } \\
\hline Unit & Abbreviation & & \\
\hline Multiply & & By & To obtain \\
\hline Acre & & 0.4047 & Square hectometer \\
\hline Acre-foot & acre-ft & 0.001233 & Cubic hectometer \\
\hline $\begin{array}{l}\text { Acre-foot per } \\
\text { square mile }\end{array}$ & acre-ft/mi ${ }^{2}$ & 476.1 & $\begin{array}{l}\text { Cubic meter per } \\
\text { square kilometer }\end{array}$ \\
\hline $\begin{array}{l}\text { Cubic foot per } \\
\text { second }\end{array}$ & $\mathrm{ft}^{3} / \mathrm{s}$ & 0.02832 & $\begin{array}{l}\text { Cubic meter per } \\
\text { second }\end{array}$ \\
\hline Foot & $\mathrm{ft}$ & 0.3048 & Meter \\
\hline Foot per mile & $\mathrm{ft} / \mathrm{mi}$ & 0.1894 & Meter per kilometer \\
\hline Gallon per minute & $\mathrm{gal} / \mathrm{min}$ & 0.06309 & Liter per second \\
\hline Inch & in. & $\begin{array}{l}25.40 \\
2.540\end{array}$ & $\begin{array}{l}\text { Millimeter } \\
\text { Centimeter }\end{array}$ \\
\hline Mile & $\mathrm{mi}$ & 1.609 & Kilometer \\
\hline Square foot & $\mathrm{ft}^{2}$ & 0.0920 & Square meter \\
\hline Square mile & $\mathrm{mi}^{2}$ & 2.590 & Square kilometer \\
\hline $\begin{array}{l}\text { Ton (short, } \\
2,000 \text { pounds) }\end{array}$ & & 0.9072 & Megagram (metric ton) \\
\hline
\end{tabular}

Chemical concentration and water temperature are given in metric units. Chemical concentration is given in milligrams per liter $(\mathrm{mg} / \mathrm{L})$ or micrograms per liter $(\mu \mathrm{g} / \mathrm{L})$. Milligrams per liter is a unit expressing the concentration of chemical constituents in solution as weight (milligrams) of solute per unit volume (liter) of water. One thousand micrograms per liter is equivalent to one milligram per liter. For concentrations less than $7,000 \mathrm{mg} / \mathrm{L}$, the numerical value is about the same as for concentrations in parts per million.

Water temperature is given in degrees Celsius $\left({ }^{\circ} \mathrm{C}\right)$, which can be converted to degrees Fahrenheit $\left({ }^{\circ} \mathrm{F}\right)$ by the following equation: ${ }^{\circ} \mathrm{F}=1.8\left({ }^{\circ} \mathrm{C}\right)+32$.

Radioactive concentration is given in picocuries per liter, which is a unit quantity of any radioactive material in which $3.7 \times 10^{-2}$ disintegrations occur per second (picocurie) per unit volume (liter) of water.

\section{NATIONAL GEODETIC VERTICAL DATUM OF 1929}

National Geodetic Vertical Datum of 1929 is used in this report. It is a geodetic datum derived from a general adjustment of the first-order level nets of both the United States and Canada, formerly called mean sea level. 


\title{
Hydrology of the Ferron Sandstone Aquifer and Effects of Proposed Surface-Coal Mining in Castle Valley, Utah
}

\author{
By Gregory C. Lines and Daniel J. Morrissey
}

\section{Abstract}

Coal in the Ferron Sandstone Member of the Mancos Shale of Cretaceous age has traditionally been mined by underground techniques in the Emery Coal Field in the southern end of Castle Valley in east-central Utah. However, approximately 99 million tons are recoverable by surface mining. Ground water in the Ferron is the sole source of supply for the town of Emery, but the aquifer is essentially untapped outside the Emery area.

The Ferron Sandstone Member crops out along the eastern edge of Castle Valley and generally dips $2^{\circ}$ to $10^{\circ}$ to the northwest. Sandstones in the Ferron are enclosed between relatively impermeable shale in the Tununk and Blue Gate Members of the Mancos Shale. Along the outcrop, the Ferron ranges in thickness from about 80 feet in the northern part of Castle Valley to 850 feet in the southern part. The Ferron also generally thickens in the subsurface downdip from the outcrop. Records from wells and test holes indicate that the full thickness of the Ferron is saturated with water in most areas downdip from the outcrop area.

Tests in the Emery area indicate that transmissivity of the Ferron sandstone aquifer ranges from about 200 to 700 feet squared per day where the Ferron is fully saturated. Aquifer transmissivity is greatest near the Paradise Valley-Joes Valley fault system where permeability has been increased by fracturing. Storage coefficient ranges from about $10^{-6}$ to $10^{-3}$ where the Ferron sandstone aquifer is confined and probably averages $5 \times$ $10^{-2}$ where it is unconfined.

The largest source of recharge to the Ferron sandstone aquifer in the Emery area is subsurface inflow from the Wasatch Plateau to the west (about 2.4 cubic feet per second during 1979), most of which moves laterally through the more permeable zone along the Paradise Valley-Joes Valley fault system. Little water is recharged to the aquifer by the 8 inches of normal annual precipitation on the outcrop area. Natural discharge from the aquifer is mainly leakage to alluvium along streams in the outcrop area and leakage to the enclosing shales in the Tununk and Blue Gate Members. Discharge from wells that tap the Ferron in Castle Valley averaged about 0.3 cubic foot per second during 1979. Discharge from the underground Emery Mine averaged about 0.7 cubic foot per second during 1979 and was the largest manmade discharge from the aquifer.

The largest quantities of water are available from the Ferron sandstone aquifer within about 2 miles of the Paradise Valley-Joes Valley fault system in the Emery area. Most wells in this area naturally flow at the land surface at rates less than 100 gallons per minute, but yields could be increased by pumping. Wells that fully penetrate the aquifer in this area could be expected to produce 100 to 500 gallons per minute if pumped. In the northern two-thirds of Castle Valley the Ferron would probably not yield more than 10 gallons per minute to individual wells.

The concentration of dissolved solids in water from the Ferron sandstone aquifer in the Emery area increases eastward from the Paradise Valley-Joes Valley fault system toward the outcrop area of the Ferron, in the general direction of ground-water movement. Dissolved-solids concentrations also increase upward in the aquifer in areas downdip from the outcrop. In the Emery area, dissolved-solids concentrations in water from the Ferron ranged from less than 500 to more than $8,000 \mathrm{mg} / \mathrm{L}$ (milligrams per liter) during 1979. Deterioration in water quality in the Emery area usually is due to increased concentrations of dissolved sodium and sulfate. In the northern two-thirds of Castle Valley, dissolved-solids concentrations usually exceed $3,000 \mathrm{mg} / \mathrm{L}$, and several test holes and gas wells have yielded water from the Ferron with chloride concentrations greater than $10,000 \mathrm{mg} / \mathrm{L}$ and dissolved-solids concentrations greater than $20,000 \mathrm{mg} / \mathrm{L}$.

Quitchupah Creek, near the underground Emery Mine, and Christiansen Wash, downstream from a proposed surface-coal mine in the Emery area, were gaged during the 1979 wateryear, and stream discharges averaged 6.7 and 2.8 cubic feet per second. There were large seasonal variations in water quality in both streams during the water year. Observed dissolved-solids concentrations at the gaging station on Quitchupah Creek ranged from 695 to $3,960 \mathrm{mg} / \mathrm{L}$, and observed suspended-sediment concentrations ranged from 111 to $27,000 \mathrm{mg} / \mathrm{L}$. At the station on Christiansen Wash, observed dissolvedsolids concentrations ranged from 582 to $4,470 \mathrm{mg} / \mathrm{L}$ and suspended-sediment concentrations ranged from 3 to $4,870 \mathrm{mg} / \mathrm{L}$.

A three-dimensional digital-computer model was used to simulate ground-water flow in the Ferron sandstone aquifer in the Emery area. The model also was used to predict the effects of dewatering of a proposed surface mine on aquifer potentiometric surfaces and the base flow of streams. The computer model was calibrated with water-level data collected during 1979. Mainly because 
it was not possible to verify the model with historic data for aquifer response to manmade discharges, predictions made with the model are considered to be semiquantitative.

Discharge from the proposed surface mine is predicted to average about 0.3 cubic foot per second during the 15 years of mine operation. Dewatering of the mine would affect the potentiometric surfaces of all sections of the Ferron sandstone aquifer, but the greatest effects would be in the upper section. Drawdowns in the potentiometric surface of the upper section of the aquifer greater than 5 feet are predicted to extend about 2 miles from the surface mine after 15 years of operation. Mine dewatering would also induce downward leakage of water into the Ferron from shale in the Blue Gate Member, and this could cause a deterioration in water quality in the upper section of the aquifer in some areas. West of the surface mine, however, the quality of water in the upper section of the aquifer might improve as the amount of saline water leaking downward from the Blue Gate Member would be small in comparison to the amount of water that would move laterally through the aquifer from the west.

Modeling results indicate that, except for Christiansen Wash, the dewatering of the proposed surface mine would not affect the base flow of streams. If water from the mine were discharged into Christiansen Wash, the base flow would increase accordingly. The dissolved-solids concentration of water in Christiansen Wash also would be increased, at least during some periods, if mine water were discharged into the stream.

Laboratory experiments indicate that if only precipitation were allowed to infiltrate mine spoil, water in the spoil would be of better quality than most ground water in the mine area and about the same quality as water in Christiansen Wash. However, the management of the spoil to reduce surface-water infiltration and spoil placement so that pyritic material is mixed with calcareous material would minimize the deterioration of water quality in Christiansen Wash.

Sediment loads of streams downstream from the mine would not increase significantly if reclaimed slopes were graded to the least possible angle, if revegetation were prompt so as to stabilize the stockpiled topsoil and backfilled overburden, if runoff were channeled from the disturbed mine area through sediment ponds, and if Christiansen Wash were permanently diverted around the mine area. The long-term sediment yield from the disturbed area could actually decrease if vegetative cover were improved from premining conditions and if sediment ponds were properly maintained.

\section{INTRODUCTION}

\section{Problem and Objectives}

Coal traditionally has been recovered by underground-mining techniques in the Emery Coal Field in the southern end of Castle Valley in east-central Utah. (See figure 1 and plate 1.) The coal is in a number of seams in the Ferron Sandstone Member of the Mancos Shale of Cretaceous age. The total coal resource of the area has been estimated at 2.06 billion tons (Doelling, 1972, p. 437). Of this total, approximately 99 million tons is recoverable by surface-mining techniques (Affolter and others, 1979, p. 1), and plans have been made for a surface mine in the area.

Ground water from the Ferron sandstone aquifer is the sole source of supply for the town of Emery (population about 370). Water from the Ferron also is used for stock watering, for a small amount of irrigation, and for a coal-washing plant in the southern end of the Emery Coal Field. The aquifer is essentially unused in the northern two-thirds of Castle Valley.

Water supplies throughout Castle Valley are being stressed by increased population that is associated with the increase in coal production from not only the Emery Coal Field but also nearby coal fields in the Wasatch Plateau and Book Cliffs. In addition to three existing coalfired powerplants now in operation in Castle Valley, a coal-gasification plant has been proposed near Emery. The gasification plant reportedly will require 5 million tons of coal and 10,000 acre-feet of water per year.

In order to anticipate the effects of increased coal

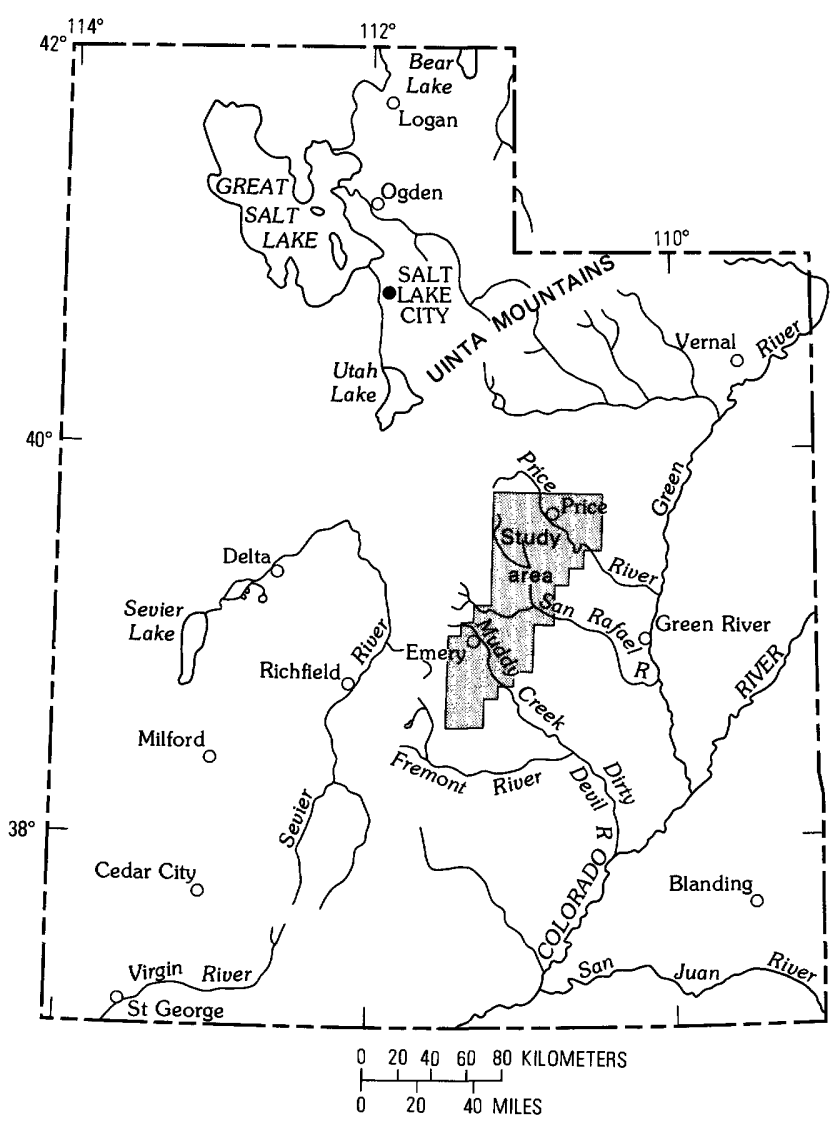

Figure 1. Map of Utah showing the study area. 
mining and related energy developments on the hydrology of the area, the U.S. Geological Survey in cooperation with the U.S. Bureau of Land Management conducted a study from October 1977 through September 1980. The objectives of the study were to determine: (1) the aquifer characteristics, recharge-discharge relationships, and the quantity and quality of water that is available from the Ferron sandstone aquifer in Castle Valley; (2) the effects of proposed surface-coal mining and associated mine dewatering on existing wells and springs, on the base flow and quality of water in streams, and on the quality of water in the Ferron sandstone aquifer; and (3) the effects of solution and erosion of stockpiled overburden at the proposed surface mine on the quality of surface water and stream aquatic life.

\section{Methods of Investigation}

Fieldwork for the study was started in October 1977 and concluded in January 1980. During this time a complete well inventory was made in Castle Valley. Wells, test holes, and springs in Castle Valley where groundwater data are available are shown on plate 1. As part of the study, 16 observation wells were constructed from a number of sources, including abandoned seismic-test holes and coal-test holes that were drilled by the Bureau of Land Management and the Geological Survey. In addition, four test holes were drilled and tested with expandable packers in the Emery area.

In the Emery area, the water level or shut-in water pressures were measured monthly at 18 wells. In addition, water-level data were obtained at about 40 other sites during the course of the study.

Instantaneous discharge of the pump that dewaters the underground Emery Mine was measured three times, and total discharge was calculated from records of pumping time supplied by Consolidation Coal Co. Withdrawals from the Emery municipal well were obtained from meter records supplied by town officials, and the discharge of other wells were measured.

Aquifer tests were conducted at nine locations to provide information on the hydraulic properties of the Ferron sandstone aquifer. Four of the tests involved a pumping well and at least one observation well, and the other tests were conducted at flowing wells or test holes.

Water samples for determination of dissolved inorganic chemical constituents were collected from about 60 wells, test holes, and springs in Castle Valley. Water samples were also collected from seepage areas in the Emery Mine. In an attempt to determine the age of water in the Ferron sandstone aquifer, carbon-14 and tritium determinations were made for water collected in the Emery Mine and from selected wells.

As part of the hydrologic monitoring in coal areas by the Geological Survey, stream-gaging stations were in- stalled on Christiansen Wash and Quitchupah Creek near the Emery Mine and the proposed surface mine. The stations were operational by August 1978. Water samples were collected monthly for determination of major inorganic chemical constituents and quarterly for determinations of suspended-sediment concentration, nutrients, trace metals, and benthic invertebrates. To supplement the scheduled quarterly sampling, additional sediment samples were collected during floods and during periods of high runoff in the spring.

Laboratory experiments were conducted to determine which minerals could be leached from the rocks that overlie the strippable coal at the proposed surface mine. The rock samples were obtained from cores collected at test holes drilled for the Bureau of Land Management. Other laboratory work included determinations of porosity, horizontal and vertical hydraulic conductivity, and grain size of core samples that were typical of rocks in the Emery Coal Field.

A three-dimensional digital-computer model of the Ferron sandstone aquifer was developed to evaluate the effects of dewatering the proposed surface mine on the potentiometric surface of the aquifer and the base flow of streams.

\section{Previous Investigations}

Lupton (1916) conducted a comprehensive study of the geology and coal resources of Castle Valley. Additional geologic information on the Emery Coal Field was presented by Doelling (1972). Information on the stratigraphy and depositional history of the Ferron Sandstone Member was presented by Katich (1951, 1953, and 1954), Davis (1954), Hale (1972), and Cotter (1975a, b, and 1976).

Ground water in bedrock aquifers in the Colorado Plateau, including the Ferron sandstone aquifer, was described by Feltis (1966). During the 1970's several hydrologic studies were conducted in Castle Valley. The quality of surface water in the Price River and Dirty Devil River basins was described by Mundorff (1972 and 1979). Hydrologic conditions in the Wasatch Plateau and Book Cliffs Coal Fields were described by Waddell, Contratto, Sumsion, and Butler (1979). Some hydrologic data from the Emery area are included in reports by Waddell, Vickers, Upton, and Contratto (1978) and Sumsion (1979). Reclamation of possible surface-mine lands in the Emery Coal Field was described by Geoscientific Systems and Consulting (1979).

\section{Acknowledgments}

The writers wish to express their appreciation to Consolidation Coal Co., Hidden Valley Coal Co., and Western States Minerals Co. for supplying geologic and 
hydrologic information from their testing and monitoring programs and for allowing access to their property for test drilling and other studies. We are grateful to the townspeople of Emery for supplying records of water use and for allowing an aquifer test to be conducted on the municipal. well. Thanks are also given to the many landowners in Castle Valley who granted permission to drill test holes and to sample and test wells.

\section{Well-, Spring-, and Site-Numbering System}

The system of numbering wells and springs in Utah is based on the cadastral land-survey system of the U.S. Government. The number, in addition to designating the well or spring, describes its position in the land net. By the land-survey system, the State is divided into four quadrants by the Salt Lake base line and meridian, and these quadrants are designated by the uppercase letters A, B, $C$, and $D$, indicating the northeast, northwest, southwest, and southeast quadrants, respectively. Numbers designating the township and range (in that order) follow the quadrant letter, and all three are enclosed in parentheses. The number after the parentheses indicates the section, and is followed by three letters indicating the quarter section, the quarter-quarter section, and the quarter-quarter-quarter section-generally 10 acres $^{1}$; the letters $a, b, c$, and d indicate, respectively, the northeast, northwest, southwest, and southeast quarters of each subdivision. The number after the letters is the serial number of the well or spring with the 10-acre tract; the letter " $S$ " preceding the serial number denotes a spring. If a well or spring cannot be located within a 10-acre tract, one or two location letters are used and the serial number is omitted. Thus (D-226) $23 \mathrm{adb}-1$ designates the first well constructed or visited in the $\mathrm{NW}^{1 / 4} \mathrm{SE}^{1 / 4 \mathrm{NE}^{1 / 4}} \mathrm{sec} .23$, T. $22 \mathrm{~S}$, , R. 6 E. Other sites where hydrologic data were collected are numbered in the same manner, but three letters are used after the section number and no serial number is used. The numbering system is illustrated in figure 2 .

\section{STRATIGRAPHY}

\section{By Thomas A. Ryer}

The Ferron Sandstone Member of the Mancos Shale, the coal-bearing unit in the Emery Coal Field, is exposed in a series of prominent cliffs in the southern part of Castle Valley. The escarpment produced by the Ferron defines the eastern limit of Castle Valley. The Ferron cliffs attain their maximum development between the town of Moore and the southern end of Castle Valley. The thickness of

\footnotetext{
'Although the basic land unit, the section, is theoretically $1 \mathrm{mi}^{2}$, many sections are irregular. Such sections are subdivided into 10-acre tracts, generally beginning at the southeast corner. and the surplus or shortage is taken up in the tracts along the north and west sides of the rection
}

the Ferron generally increases southward from about 300 feet near Moore to about 850 feet near the southern end of Castle Valley. (See plate 2.) The Ferron dips $2^{\circ}$ to $10^{\circ}$ to the northwest beneath the surface of Castle Valley. The altitude of the top of the Ferron is shown on plate 3.

In the area between Moore and the southern end of Castle Valley, the Ferron consists of massive beds of very fine to medium-grained, delta-front sandstone, prodelta mudstones, and a wide variety of delta-plain rock types (mainly carbonaceous shale, coal, mudstone, siltsone, and thin-bedded, rippled, very fine grained sandstone). The Ferron outcrop along Quitchupah Creek near Emery is shown in figure 3.

North of Moore, the Ferron escarpment gradually becomes more subdued until, at the latitude of Castle Dale, the Ferron is represented by a pair of units of very fine grained, silty sandstone each about 50 feet thick. The upper unit of this pair, shown in figure 4 , crops out continuously along the east side of Castle Valley from about Emery to as far as Wellington at the northern end of Castle Valley. The lower unit pinches out northward near the town of Cleveland. One or more ledge-forming units of very fine grained sandstone and sandy siltstone occur at the stratigraphic level of the Ferron between Wellington and the Utah-Colorado State line, and these are mapped collectively as Ferron Sandstone Member on the geologic map of Utah (Stokes, 1964).

The first, and still the most comprehensive study of the geology and mineral resources of the Ferron Sandstone Member was conducted by Lupton (1916). Minor modification and updating of Lupton's coal-resource calculations were made by Doelling (1972). Lupton (1916, p. 31) named the Ferron Sandstone Member for exposures "in the vicinity of Ferron and Emery." Though he cited no type locality for the member, a section along Ivie Creek, about 8 miles south of Emery, was presented as representative. It is clear from Lupton's description of the stratigraphy of the Ferron $(1916$, p. 31-33) that he considered the pair of very fine grained sandstones in the northern part of Castle Valley to be a northward extension of the thicker, coal-bearing sequence of strata exposed near Emery. Later work by Katich (1951, 1953, and 1954), Davis (1954), and Cotter (1975a, b, and 1976) demonstrate that this is not the case. The pair of Ferron units of northern Castle Valley are about 100 feet stratigraphically lower than the lowest delta-front sandstone of the Ferron Sandstone Member that crops out south of Emery, and they pinch out toward the south into the marine shale of the Tununk Member of the Mancos (see fig. 5). The two Ferron units of northern Castle Valley were informally named, in ascending stratigraphic order, the Clawson and Washboard units of the Ferron Sandstone Member by Cotter (1975a). Cotter's informal names are used in this report. 
The Ferron Sandstone Member in Castle Valley, then, contains two parts that are stratigraphically distinct and of different origin. The older, stratigraphically lower part of the Ferron consists of a pair of units of very fine grained, silty sandstone that accumulated in a shallow, open-marine environment situated well offshore. These units are the Clawson and Washboard units of Cotter (1975a). They are separated from the younger, upper part of the Ferron by as much as 100 feet of marine shale. The upper part of the Ferron, the product of deposition in a delta system, is characterized by massive beds of very fine to medium-grained sandstone and beds of coal. The upper part of the Ferron thins to the north, interfingers with marine shale of the Blue Gate Member of the Mancos

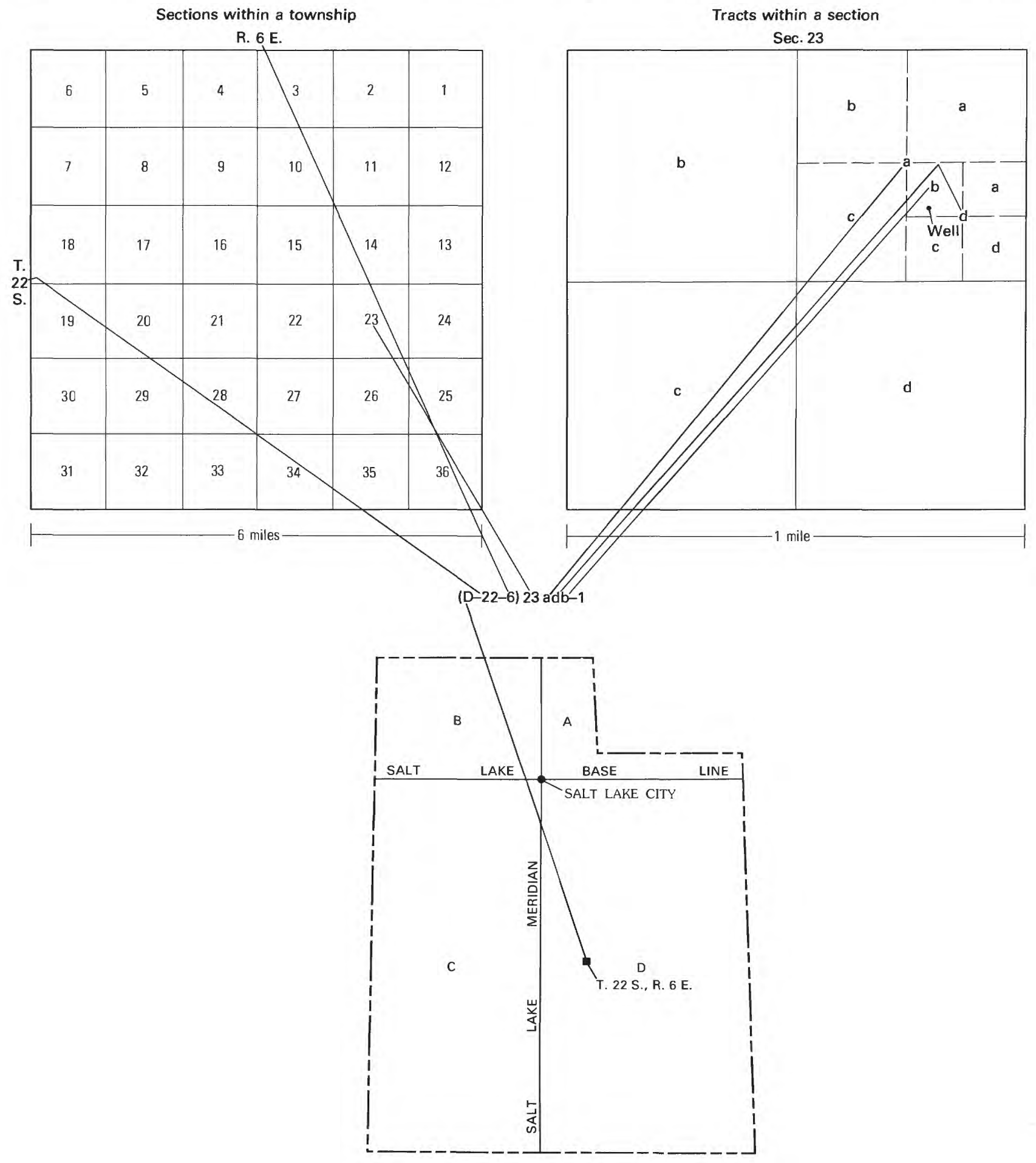

Figure 2. Well-, spring-, and site-numbering used in Utah. 


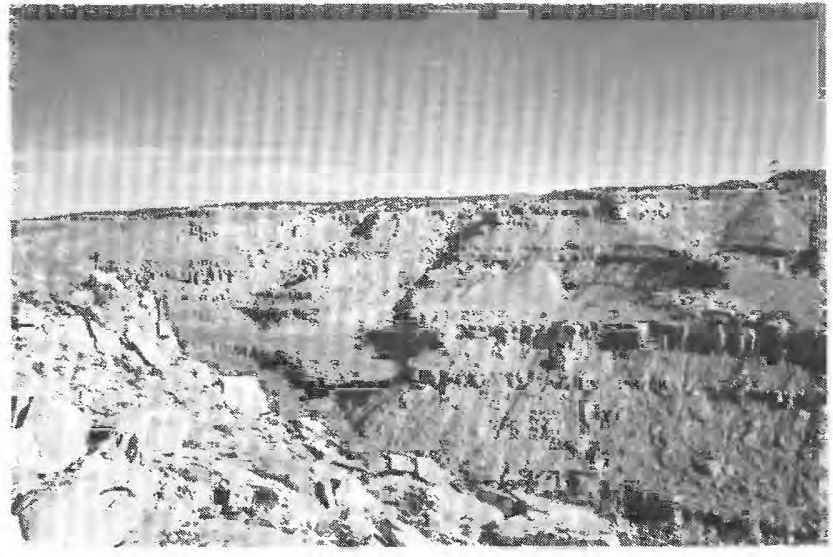

Figure 3. Outcrop of the Ferron Sandstone Member of the Mancos Shale along Quitchupah Creek near Emery. View facing north.

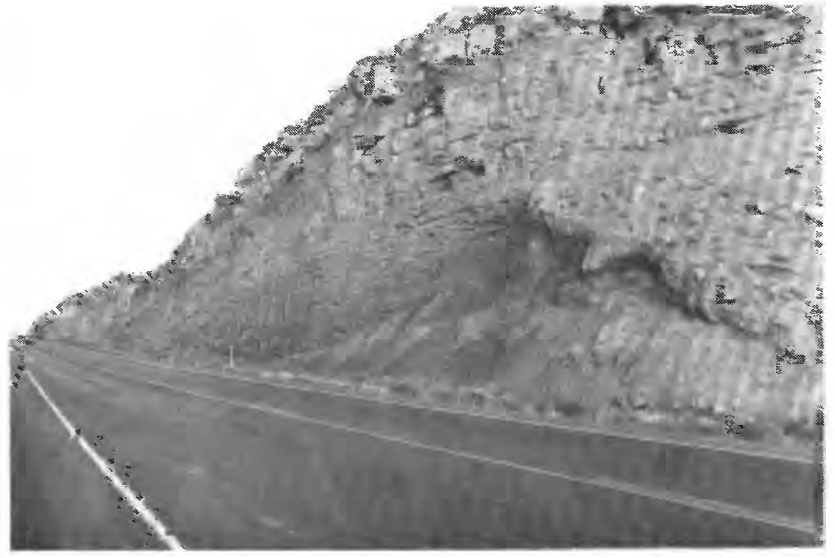

Figure 4. Outcrop of the Washboard unit of Cotter (1975a) of the Ferron Sandstone Member of the Mancos Shale along U.S. Highway 6 southeast of Wellington. View facing northwest.

$\begin{array}{ccc}\text { Last Chance } \\ \text { Creek } & \text { Emery } & \text { Ferron } \\ \text { Dale }\end{array}$

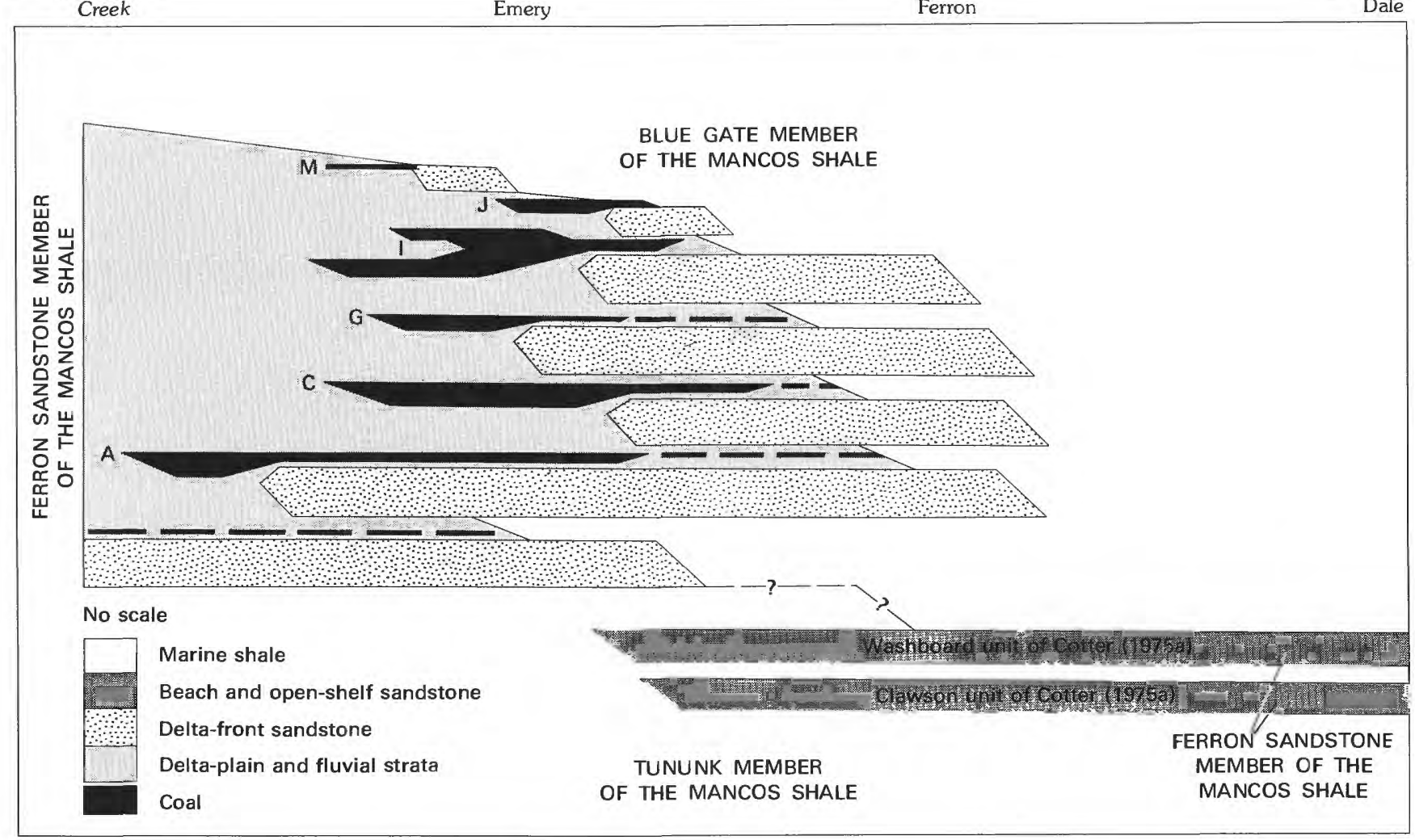

Figure 5. Diagrammatic southwest-northeast section showing stratigraphic relationships of the various units of the Ferron Sandstone Member and the Tununk and Blue Gate Members of the Mancos Shale in Castle Valley. Major coal beds carry the letter designations of Lupton (1916).

Shale, and finally pinches out between Ferron and Castle Dale. The two parts of the Ferron are not differentiated on the thickness and structure contour maps (pls. 2 and 3 ). The outcrop areas of the Ferron Sandstone Member and other geologic units in the Emery area are shown in figure 6.

\section{FERRON SANDSTONE AQUIFER Aquifer Characteristics Thickness}

The Ferron aquifer in Castle Valley consists of the whole thickness of the Ferron Sandstone Member. The thickness of the Ferron varies considerably in the study 


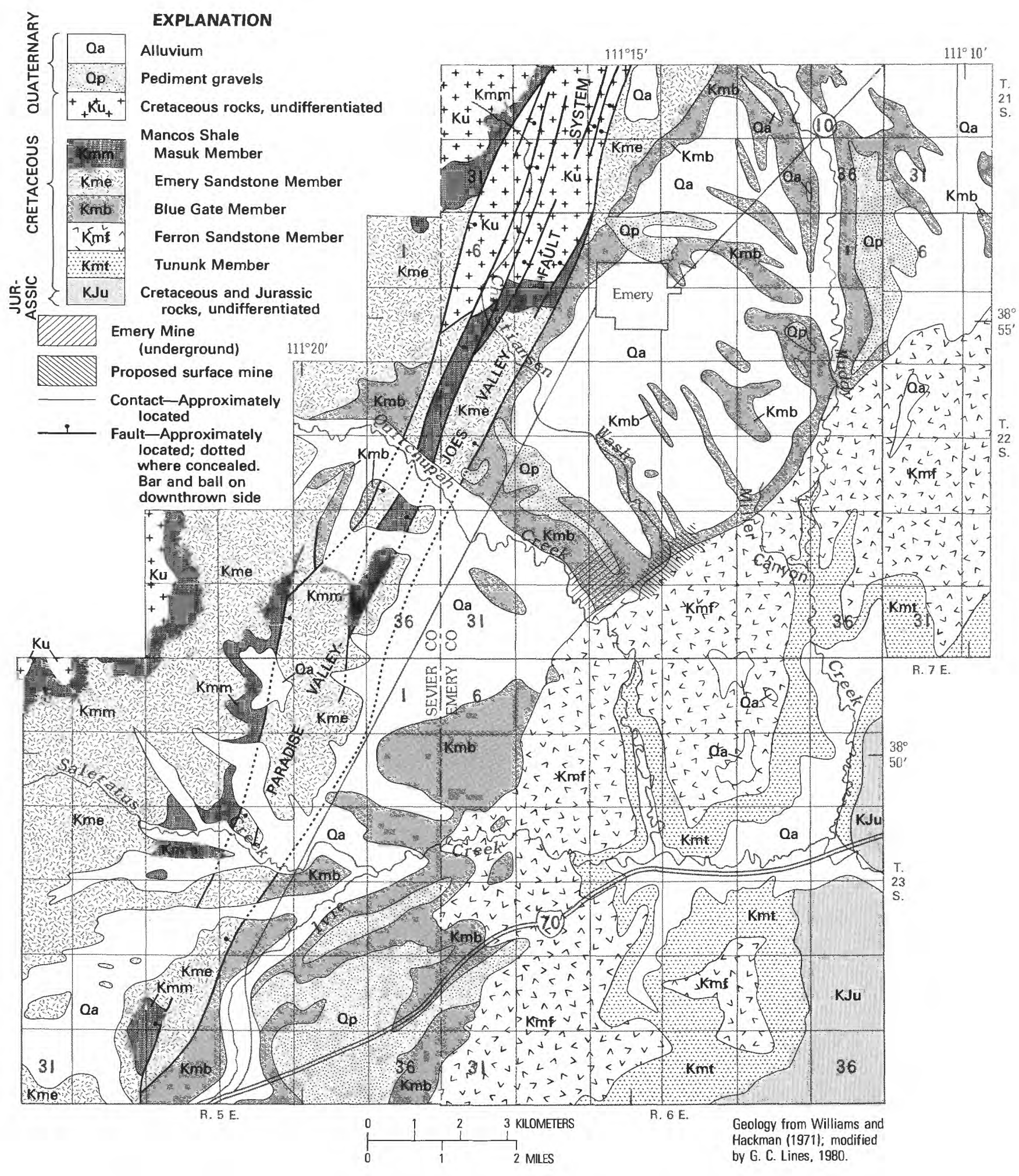

Figure 6. Geology of the Emery area.

area (pl. 2). Along the outcrop, the Ferron thickness varies from about 80 feet in the northern part of Castle Valley near Mounds to 850 feet in the southern part along Last Chance Creek (Lupton, 1916, pl. IV). The Ferron also generally thickens in the subsurface downdip from the outcrop area.

Records from wells and test holes indicate that a short distance from the outcrop area, the complete thick- 
ness of the Ferron is usually saturated with water. In the area of the proposed surface coal mine near Emery, the saturated thickness of the Ferron is about 450 feet. In the outcrop area, not all the Ferron is saturated with water; and at the higher altitudes along the outcrop, much of it is unsaturated.

\section{Hydraulic Conductivity ${ }^{2}$}

Hydraulic conductivity was determined in the laboratory for 17 rock samples from the Ferron Sandstone Member obtained from core holes in the Emery area. Hydraulic conductivity was determined in horizontal and vertical directions for 15 of the samples, porosity was determined for all but one sample, and grain size was determined for 10 sandstone samples.

Results of the laboratory determinations are summarized in table 1 . The data indicate a large variation in the porosity and hydraulic conductivity of the sandstone. This may be due to differences in cementation and compaction between samples. Unconsolidated sand, similar in size and sorting, would have a porosity of about 40 percent (Johnson, 1967, fig. 3) as compared to the average of 16 percent for the sandstone in the Ferron.

In all the sandstone samples, the difference between horizontal and vertical hydraulic conductivities was less than one order of magnitude. The average hydraulic conductivity of delta-front sandstone samples was $1.0 \times 10^{-1}$ $\mathrm{ft} / \mathrm{d}$ in the horizontal direction and $9.1 \times 10^{-2} \mathrm{ft} / \mathrm{d}$ in the vertical. Similarly, hydraulic conductivity of the fluviatile sandstone samples averaged $1.5 \times 10^{-1} \mathrm{ft} / \mathrm{d}$ in the horizontal direction and $9.9 \times 10^{-2} \mathrm{ft} / \mathrm{d}$ in the vertical. Hydraulic conductivity of the shale and siltstone samples was much less than that of most of the sandstones, and it averaged $3.8 \times 10^{-4} \mathrm{ft} / \mathrm{d}$ in the horizontal direction and $1.3 \times 10^{-5} \mathrm{ft} / \mathrm{d}$ in the vertical.

\section{Transmissivity ${ }^{3}$}

Nine aquifer tests were conducted on the Ferron sandstone aquifer in the Emery area, and the results are summarized in table 2. Considering the thickness and lithology of the aquifer tapped by the discharging well

\footnotetext{
${ }^{2}$ The hydraulic conductivity of a water-bearing materal is the volume of water that wilt move through a unit cross section of the material in unit time under a unit hydraulic gradient. The units for hydraulic conductivity are cubic feet per day per square foot $\left[\left(\mathrm{ft}^{3} / \mathrm{d}\right) / \mathrm{ft}^{2}\right]$. which reduces to $\mathrm{ft} / \mathrm{d}$. The term hydraulic conductivity replaces the term field coefficient of permeability, which was formerly used by the Geological Survey and which was reported in units of gallons per day per square foot. To convert a value of field coefficient of permeability to the equivalent value of hydraulic conductivity. divide by 7.48 ; to convert from hydraulic conductivity to coefficient of permeability, multiply by 7.48

${ }^{3}$ Transmissivity is the rate at which water is transmitted through a unit width of the aquifer under a unit hydraulic gradient The units for transmissivity are cubic feet per day per foot $\left[\left(\mathrm{ft}^{3} / \mathrm{d}\right) / \mathrm{ft}\right]$, which reduces to $\mathrm{ft}^{2} / \mathrm{d}$. The term transmissivity replaces the term coefficient of transmissibility, which was formerly used by the Geological Survey and which was reported in unts of gallons per day per foot. To convert a value for coefficient of transmissibility to the equivalent value of transmissivity, divide by 7.48 ; to convert from transmissivity to coefficient of transmissibility, multiply by 7.48 .
}

at each test site, some transmissivity values calculated from the tests agree fairly well with what would be expected from the hydraulic conductivities determined in the laboratory. In some cases, particularly at test sites near the Paradise Valley-Joes Valley fault system, the computed transmissivities of several hundred feet squared per day are larger than would be expected from the laboratory data. This is believed to be due to secondary permeability in the form of fractures.

None of the test wells fully penetrate the Ferron sandstone aquifer. However, where the Ferron is extensively fractured, thus increasing hydraulic connection in the aquifer, the computed transmissivities of several hundred feet squared per day fairly accurately represent the transmissivity of the full thickness of the aquifer. Tests that were conducted more than about 2 miles from the Paradise Valley-Joes Valley fault system usually indicated transmissivities of $100 \mathrm{ft}^{2} / \mathrm{d}$ or less. Computed transmissivities from these tests probably most accurately represent the transmissivity of only a partial thickness of the aquifer because hydraulic connection is not as great as along the fault system.

Test results in the Emery area indicate that transmissivity of the Ferron sandstone aquifer ranges from about 200 to $700 \mathrm{ft}^{2} / \mathrm{d}$ downdip from the Ferron outcrop. (Compare figs. 6 and 7.) Transmissivity is less than $200 \mathrm{ft}^{2} / \mathrm{d}$ in the outcrop area of the Ferron. The decrease in transmissivity in the outcrop area is due mainly to the decrease in the saturated thickness of the aquifer rather than a decrease in hydraulic conductivity.

The transmissivity values in figure 7 were based on data from aquifer tests, lithologic information, and estimates of saturated thickness in the outcrop area. Because of secondary permeability and the nonhomogeneous nature of the aquifer, the lines of equal transmissivity are considered to be approximate. Figure 7 is presented only to depict the general pattern of increasing transmissivity from the outcrop area toward the Paradise Valley-Joes Valley fault system. Calibration of a three-dimensional digitalcomputer model of the Ferron sandstone aquifer indicated that the aquifer was simulated most accurately when transmissivity values north of about the $200-\mathrm{ft}^{2} / \mathrm{d}$ line in figure 7 were reduced by $10-30$ percent. The model is discussed in a following section of this report and is documented by Morrissey, Lines, and Bartholoma (1980).

\section{Storage}

Water in the Ferron sandstone aquifer is confined, except for possibly a few areas in the outcrop and in the upper part of the aquifer near the Emery Mine. The water is confined under pressure between shale and siltstone beds within the aquifer and between the enclosing shales in the Blue Gate and Tununk Members of the Mancos Shale. Where a well taps the confined aquifer, water is released from storage mainly by compression of the sand- 
Table 1. Laboratory determinations of porosity, hydraulic conductivity, and grain size of rock samples from the Ferron Sandstone Member of the Mancos Shale

[Determinations by Core Laboratories, Inc., Dallas, Texas]

Lithology: S, sandstone; SH, shale; SLT, siltstone; a, altered by coal burn; d, delta-front; f, fluviatile; $\mathrm{m}$, marine; $\mathrm{w}$, weathered.

Sorting coefficient: $\sqrt{Q_{3} / Q_{1}}$, where $Q_{3}$ is the size where 25 percent of the grains are 1 arger and 75 percent are smaller, and $Q_{1}$ is the size where 75 percent are larger and 25 percent are sma11er (Pettijohn, 1957, p. 37).

\begin{tabular}{|c|c|c|c|c|c|c|c|}
\hline \multirow[t]{2}{*}{ Test hole } & \multirow[t]{2}{*}{ Lithology } & \multirow{2}{*}{$\begin{array}{c}\text { Depth } \\
\text { (feet below } \\
\text { land surface) }\end{array}$} & \multirow{2}{*}{$\begin{array}{l}\text { Porosity } \\
\text { (percent) }\end{array}$} & \multicolumn{2}{|c|}{$\begin{array}{l}\text { Hydraulic conductivity } \\
\text { (feet per day) }\end{array}$} & \multirow{2}{*}{$\begin{array}{c}\text { Mean } \\
\text { grain size } \\
\text { (inches) }\end{array}$} & \multirow{2}{*}{$\begin{array}{l}\text { Sorting } \\
\text { coefficient }\end{array}$} \\
\hline & & & & Horizontal & Vertical & & \\
\hline \multirow[t]{2}{*}{$(D-22-6) 22 c d d-1$} & $S, d$ & 182 & 19 & $8.0 \times 10^{-2}$ & $1.1 \times 10^{-1}$ & $1.2 \times 10^{-2}$ & 1.28 \\
\hline & S, d & 202 & 18 & $9.8 \times 10^{-2}$ & $9.5 \times 10^{-2}$ & $1.0 \times 10^{-2}$ & 1.22 \\
\hline \multirow[t]{5}{*}{$34 c a c-1$} & $S, d$ & 84 & 17 & $2.5 \times 10^{-1}$ & $2.1 \times 10^{-1}$ & $8.5 \times 10^{-2}$ & 1.23 \\
\hline & $s, f$ & 125 & 18 & $4.9 \times 10^{-3}$ & $5.1 \times 10^{-3}$ & $6.6 \times 10^{-2}$ & 1.43 \\
\hline & S, d & 169 & 10 & $2.4 \times 10^{-3}$ & $2.3 \cdot \times 10^{-3}$ & $6.4 \times 10^{-2}$ & 1.50 \\
\hline & $\mathrm{s}, \mathrm{d}$ & 181 & 13 & $5.6 \times 10^{-2}$ & $4.1 \times 10^{-2}$ & $1.0 \times 10^{-2}$ & 1.68 \\
\hline & $\mathrm{SH}, \mathrm{m}$ & 200 & -- & -- & $5.5 \times 10^{-6}$ & -- & -- \\
\hline \multirow[t]{6}{*}{$(D-23-6) 3 d d c-1$} & $\mathrm{~S}, \mathrm{f}, \mathrm{w}$ & 9 & 20 & $7.7 \times 10^{-1}$ & $3.2 \times 10^{-1}$ & $1.2 \times 10^{-2}$ & 1.18 \\
\hline & $\mathrm{S}, \mathrm{f}, \mathrm{w}$ & 34 & 18 & $1.1 \times 10^{-2}$ & $2.9 \times 10^{-3}$ & -- & - \\
\hline & $\mathrm{s}, \mathrm{f}, \mathrm{a}$ & 54 & 14 & $7.3 \times 10^{-4}$ & -- & -- & -- \\
\hline & $\mathrm{s}, \mathrm{f}$ & 164 & 17 & $2.7 \times 10^{-2}$ & $6.8 \times 10^{-3}$ & $1.3 \times 10^{-2}$ & 1.45 \\
\hline & S, d & 224 & 12 & $7.3 \times 10^{-4}$ & $2.9 \times 10^{-3}$ & -- & -- \\
\hline & $\mathrm{s}, \mathrm{d}$ & 283 & 20 & $3.2 \times 10^{-1}$ & $2.6 \times 10^{-1}$ & $6.3 \times 10^{-2}$ & 1.44 \\
\hline \multirow[t]{4}{*}{$((D-24-6) 5 a b b-1$} & $S, f$ & 42 & 20 & $8.8 \times 10^{-2}$ & $1.6 \times 10^{-1}$ & $1.2 \times 10^{-2}$ & 1.21 \\
\hline & SLT, m & 92 & 11 & $3.2 \times 10^{-5}$ & $2.9 \times 10^{-6}$ & -- & -- \\
\hline & $\mathrm{SLT}, \mathrm{m}$ & 151 & 16 & $7.3 \times 10^{-4}$ & $3.2 \times 10^{-5}$ & -- & -- \\
\hline & S, d & 342 & 15 & $9.8 \times 10^{-3}$ & $4.6 \times 10^{-3}$ & -- & - \\
\hline
\end{tabular}

Table 2. Summary of aquifer tests conducted on the Ferron sandstone aquifer in the Emery area, 1978-79

Method of test analysis: C, constant drawdown (Lohman, 1972, p. 23-26); L, Hantush modified method for leaky confined aquifer (Lohman, 1972, p. 32-34); R, straight-1ine recovery method (Lohman, 1972, p. 26 and 27).

\begin{tabular}{|c|c|c|c|c|c|c|c|c|c|c|}
\hline Loca & tion & 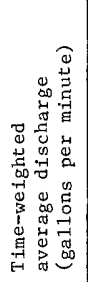 & 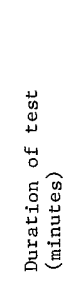 & 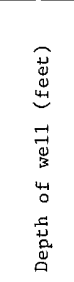 & 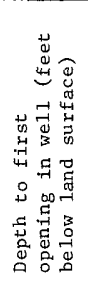 & 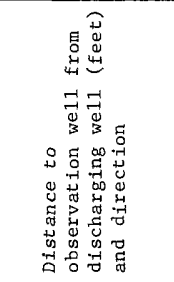 & 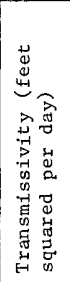 & 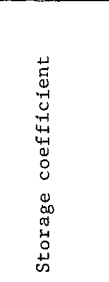 & 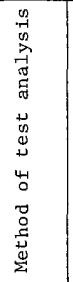 & Remarks \\
\hline \multirow[t]{8}{*}{$(D-22-6)$} & $4 c a b-1$ & 51 & 150 & 1,614 & 1,586 & - & $\begin{array}{l}800 \\
600\end{array}$ & \multirow{2}{*}{ (1) } & $\begin{array}{l}\mathrm{C} \\
\mathrm{R}\end{array}$ & $\begin{array}{l}\text { Open hole below } 1,586 \mathrm{ft} \text { in basal section of } \\
\text { Ferron sandstone aquifer. }\end{array}$ \\
\hline & $17 a b c-1$ & 176 & 310 & 1,543 & 1,368 & - & $\begin{array}{l}400 \\
600\end{array}$ & & $\begin{array}{l}\mathrm{C} \\
\mathrm{R}\end{array}$ & $\begin{array}{l}\text { Taps basal section of Ferron sandstone } \\
\text { aquifer. }\end{array}$ \\
\hline & $17 a b c-2$ & 3 & 120 & 1,100 & 1,040 & -- & 30 & -- & $\mathrm{R}$ & $\begin{array}{l}\text { Expandable packer set at } 1,040 \mathrm{ft} \text {; open hole } \\
\text { below in upper section of Ferron sandstone } \\
\text { aquifer. }\end{array}$ \\
\hline & $\begin{array}{l}22 \mathrm{cdd}-1 \\
22 \mathrm{cdd}-2\end{array}$ & 10 & 1,500 & $\begin{array}{l}275 \\
270\end{array}$ & $\begin{array}{l}100 \\
230\end{array}$ & 375, northwest & $\begin{array}{l}10 \\
20\end{array}$ & $2 \times 10^{-3}$ & $\begin{array}{l}\mathrm{R} \\
\mathrm{L}\end{array}$ & $\begin{array}{l}\text { Both wells tap upper coal-bearing section of } \\
\text { Ferron sandstone aquifer. }\end{array}$ \\
\hline & $26 \mathrm{bbb}-1$ & 8 & 1,500 & 349 & 40 & 174 , south & 100 & $7 \times 10^{-4}$ & L & $\begin{array}{l}\text { Both wells tap entire upper section and part } \\
\text { of basal section of Ferron sandstone } \\
\text { aquifer. }\end{array}$ \\
\hline & $27 \mathrm{cbb}-2$ & 4 & 40 & 380 & 310 & -- & 100 & -- & $\mathrm{R}$ & $\begin{array}{l}\text { Open hole below } 310 \mathrm{ft} \text { in basal section of } \\
\text { Ferron sandstone aquifer. }\end{array}$ \\
\hline & $\begin{array}{l}27 \mathrm{cbb}-5 \\
27 \mathrm{cb}-3\end{array}$ & 3 & 1,500 & $\begin{array}{l}158 \\
150\end{array}$ & $\begin{array}{r}118 \\
75\end{array}$ & 206 , north & $\begin{array}{r}40 \\
100\end{array}$ & $8 \times 10^{-4}$ & $\begin{array}{l}\mathrm{R} \\
\mathrm{L}\end{array}$ & $\begin{array}{l}\text { Both we11s tap upper section of Ferron sand- } \\
\text { stone aquifer. }\end{array}$ \\
\hline & $31 \mathrm{~d} a b-1$ & 13 & 3,065 & 406 & 360 & -- & 200 & -- & $\mathrm{R}$ & $\begin{array}{l}\text { Taps upper section of Ferron sandstone } \\
\text { aquifer. }\end{array}$ \\
\hline (D-23-6) & $\begin{array}{l}32 \mathrm{bbb}-2 \\
32 \mathrm{bbb}-3 \\
32 \mathrm{bbb}-1 \\
32 \mathrm{bda}-1 \\
32 \mathrm{bcb}-1\end{array}$ & 16 & 1,540 & $\begin{array}{l}280 \\
280 \\
282 \\
240 \\
245\end{array}$ & $\begin{array}{l}225 \\
-- \\
160 \\
200 \\
205\end{array}$ & $\begin{array}{l}\text { 480, north } \\
695 \text {, northwest } \\
480 \text {, southeast } \\
890 \text {, southwest }\end{array}$ & $\begin{array}{r}100 \\
50 \\
400 \\
90 \\
60\end{array}$ & $\begin{array}{ll}1 \times 10^{-5} \\
1 \times 10^{-5} \\
3 \times 10^{-6} \\
3 \times 10^{-5}\end{array}$ & $\begin{array}{l}R \\
L \\
L \\
L \\
L\end{array}$ & $\begin{array}{l}\text { A1l wells tap basal section of Ferron sand- } \\
\text { stone aquifer. }\end{array}$ \\
\hline
\end{tabular}

${ }^{1}$ Storage coefficient could not be determined because, due to fracturing, the effective wel1 radius was unknown. 


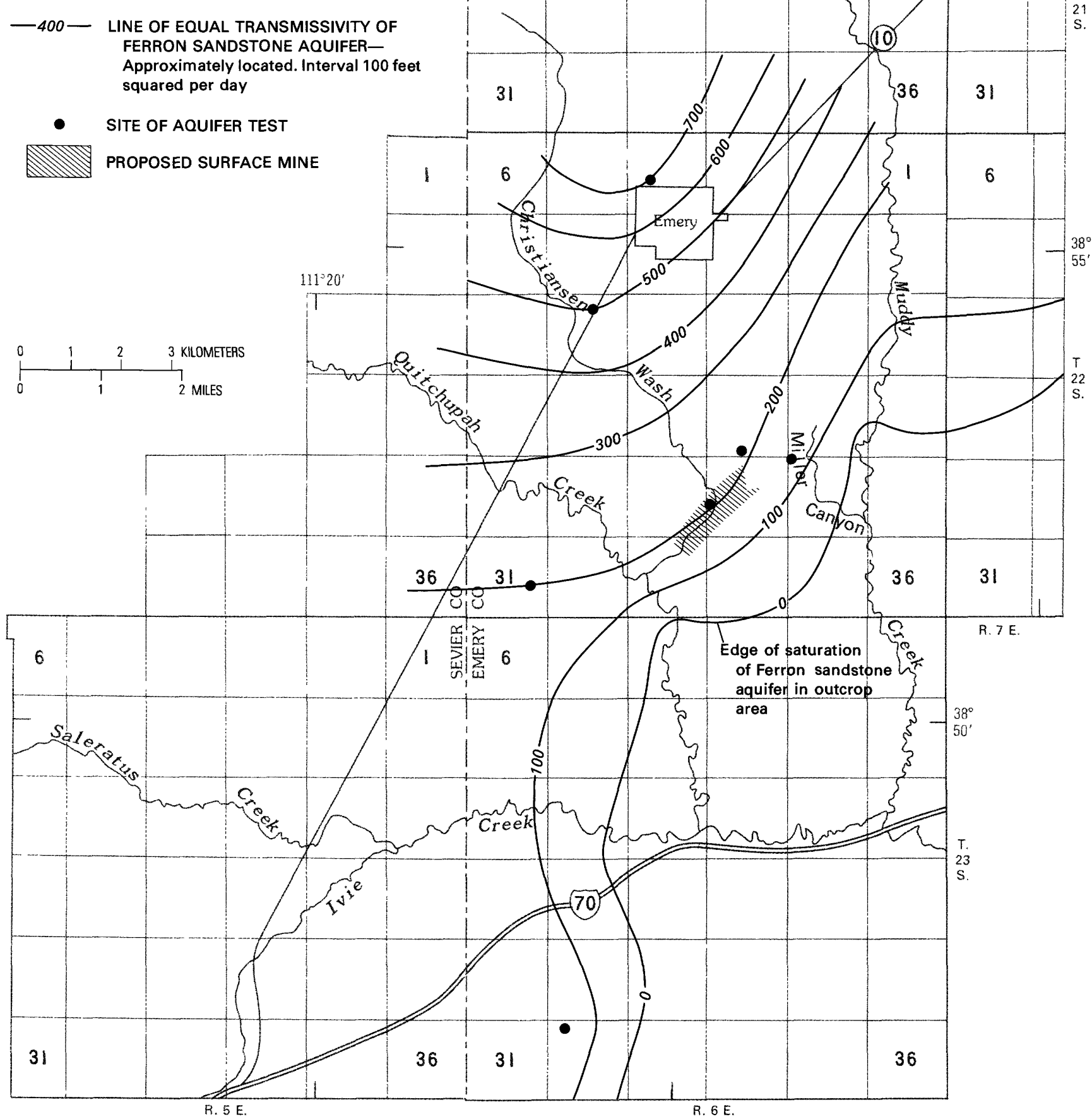

Figure 7. Transmissivity of the Ferron sandstone aquifer in the Emery area.

stone and less permeable confining beds as pressure in the aquifer declines. The quantity of water that can be released from storage from the Ferron sandstone aquifer is dependent upon the storage coefficient ${ }^{4}$, which ranges

\footnotetext{
tThe storage coefficient of an aquifer is the volume of water it releases from or takes into storage per unit urface area of the aquifer per unt change in head. Storage coefficient is a dimensionless number Under confined conditions, the storage coefficient is typically small, generally between $10^{5}$ and $10^{-3}$ Under unconfined conditions, it is much larger, typically between $5 \times 10^{-2}$ and $3 \times 10^{-1}$
}

from about $3 \times 10^{-6}$ to $2 \times 10^{-3}$ in the confined parts of the aquifer (table 2 ).

Where a well taps the unconfined aquifer, water is released from storage mainly by gravity drainage; and the storage coefficient is virtually equal to the specific yield. Aquifer tests were not conducted in an unconfined part of the Ferron sandstone aquifer. However, other studies (Johnson, 1967) have found that specific yield varies from 
about 0.01 in shales to about 0.1 in sandstones that are similar to those in the Ferron. Because the Ferron consists of both sandstone and shale, storage coefficient in the unconfined parts of the aquifer probably average about 0.05 .

\section{Potentiometric Surfaces}

The potentiometric surface (the level to which water rises in tightly cased wells) varies appreciably with depth in the Ferron sandstone aquifer. Where data permit, more than one potentiometric surface is defined in order to describe the distribution of head ${ }^{5}$ in the aquifer.

Except for the Emery area, data are lacking in Castle Valley to define the distribution of head in the Ferron sandstone aquifer and surrounding rocks. On a regional scale, however, the distribution of head in the Ferron may be similar to that in the Emery area. Petroleum-test hole (D-17-7)25ddc-1 penetrated the Ferron in the northern part of Castle Valley about 9 miles from the outcrop area; and water reportedly flowed from the hole at land surface, which was at an altitude of 7,040 feet. (See table 5.) The water level in well (D-17-10)16dda-1, which penetrates the Ferron only about 1 mile from the outcrop area, was within a few feet of land surface during 1979 at an altitude of about 5,670 feet. Information from these two sites indicates that head in the Ferron increases downdip from the outcrop area. This is consistent with head distribution observed near Emery, which is discussed in detail in the following sections of the report.

In the Emery area, downdip from the outcrop of the Ferron, head in the Ferron sandstone aquifer generally increases with depth. In most of this area, head in the Ferron is above the water table in overlying rocks. In the outcrop area of the Ferron, where there is a small amount of recharge from precipitation and where water from the Ferron leaks downward into the underlying Tununk Member, head in the aquifer decreases with depth.

\section{Basal Section}

Figure 8 shows the configuration of the potentiometric surface of the basal section of the Ferron sandstone aquifer (below the A-coal seam) in the Emery area. The contours are based on measurements of different accuracy. The potentiometric surface was determined accurately at 11 sites-in tightly cased wells that tap only the basal section and in uncased test holes drilled for the Geological Survey where an expandable packer was used to isolate the basal section.

\footnotetext{
${ }^{5}$ Head is defined by Lohman and others (1972, p. 7) as "the height above a standard datum of the surface of a column of water (or other liquid) that can be supported by the static pressure at a given point." The head is the sum of the elevation head and the pressure head. Under conditions to which Darcy's law may be applied, the velocity of ground water is so small that the velocity head is negligible.
}

Data from six other uncased test holes that penetrated the basal section also were considered in drawing the potentiometric contours. Downdip from the outcrop of the Ferron, four of the test holes flowed at land surface. Because the holes were uncased, no shut-in pressures were measured. Thus, the only thing known of the potentiometric surface was that it was at a higher altitude than land suface. Water levels also were measured, or obtained from an electric $\log$, in two nonflowing test holes that pentrated the basal section. Because the holes were not cased through the upper coal-bearing section of the Ferron Sandstone Member and the Blue Gate Member, water levels in the holes probably did not accurately represent the altitude of the potentiometric surface of the basal section of the Ferron sandstone aquifer. In most areas, except on the outcrop of the Ferron, the potentiometric surface of the basal section was probably at significantly higher altitudes (as much as 150 feet at one packer-test site) than the water levels in the uncased holes. Nevertheless, the water-level data from the six uncased test holes were useful in drawing the potentiometric contours, as the water levels in most cases represented the minimum altitudes to which water would have risen had the test holes been tightly cased.

\section{Upper Section}

Configuration of the potentiometric surface of the upper section of the Ferron sandstone aquifer (above the base of the I-coal seam) is shown in figure 9. Near the Emery Mine, many coal-test holes have been cased and are open only to the upper section. In addition, packer tests were conducted in two Geological Survey uncased test holes to determine the potentiometric surface of the upper section.

In addition to water levels measured in wells and test holes, the altitude of the I-coal seam in the Emery Mine was also considered in drawing potentiometric contours for the upper section. Observations in the mine indicate that the aquifer has been dewatered above much of the I-seam. Water production in the mine during 1979 was concentrated in those areas farthest downdip, near the working faces at the I-seam. Much of the old mine workings produced no water.

Most of the water-level data from which the potentiometric-surface maps in figures 8 and 9 were derived were collected during 1979. However, some of the data from coal-test holes are 4 to 5 years older. Even though these earlier data were used to compile the maps, the configurations of the potentiometric surfaces should fairly well represent conditions that existed in 1979.

It should be noted that the Ferron sandstone aquifer has yielded hydrogen sulfide gas and occasionally methane or carbon dioxide gas to some wells in the Emery area. When the wells flowed at the land surface, it was not 
EXPLANATION

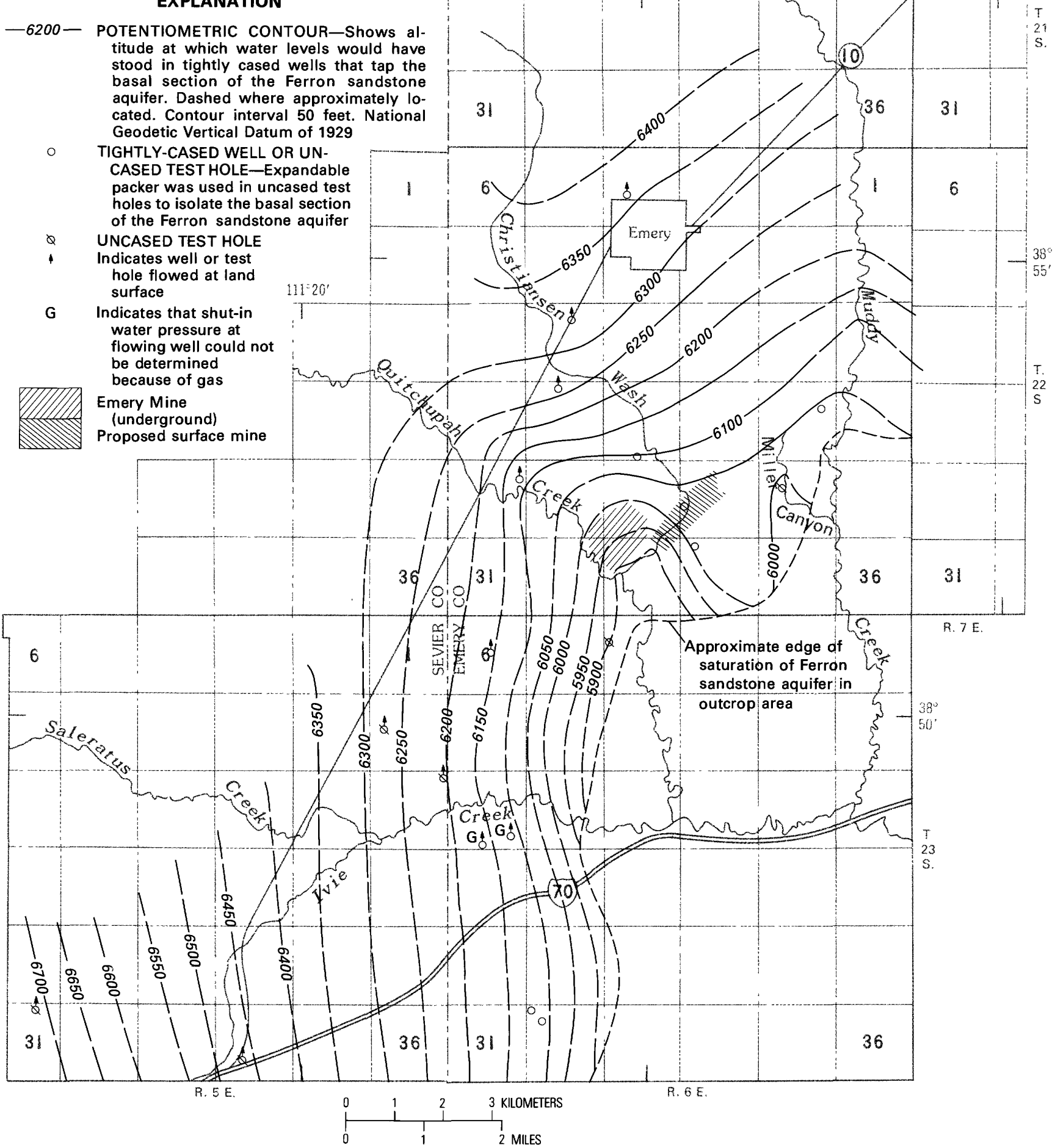

Figure 8. Potentiometric surface of the basal section of the Ferron sandstone aquifer in the Emery area, 1979.

possible to accurately determine shut-in pressures because of the gas.

\section{Adjacent Water-Bearing Zones}

The approximate configuration of the water table (the level at which pressure is atmospheric) in rocks that overlie the Ferron sandstone aquifer in the Emery area is shown in figure 10. The altitude of the water table in rocks that overlie the Ferron is defined in order to determine the direction of vertical movement of water. During the summer of 1979 , the water table in many areas was in the Blue Gate Member; but on the benches north of Quitchupah Creek, the water table was commonly in 


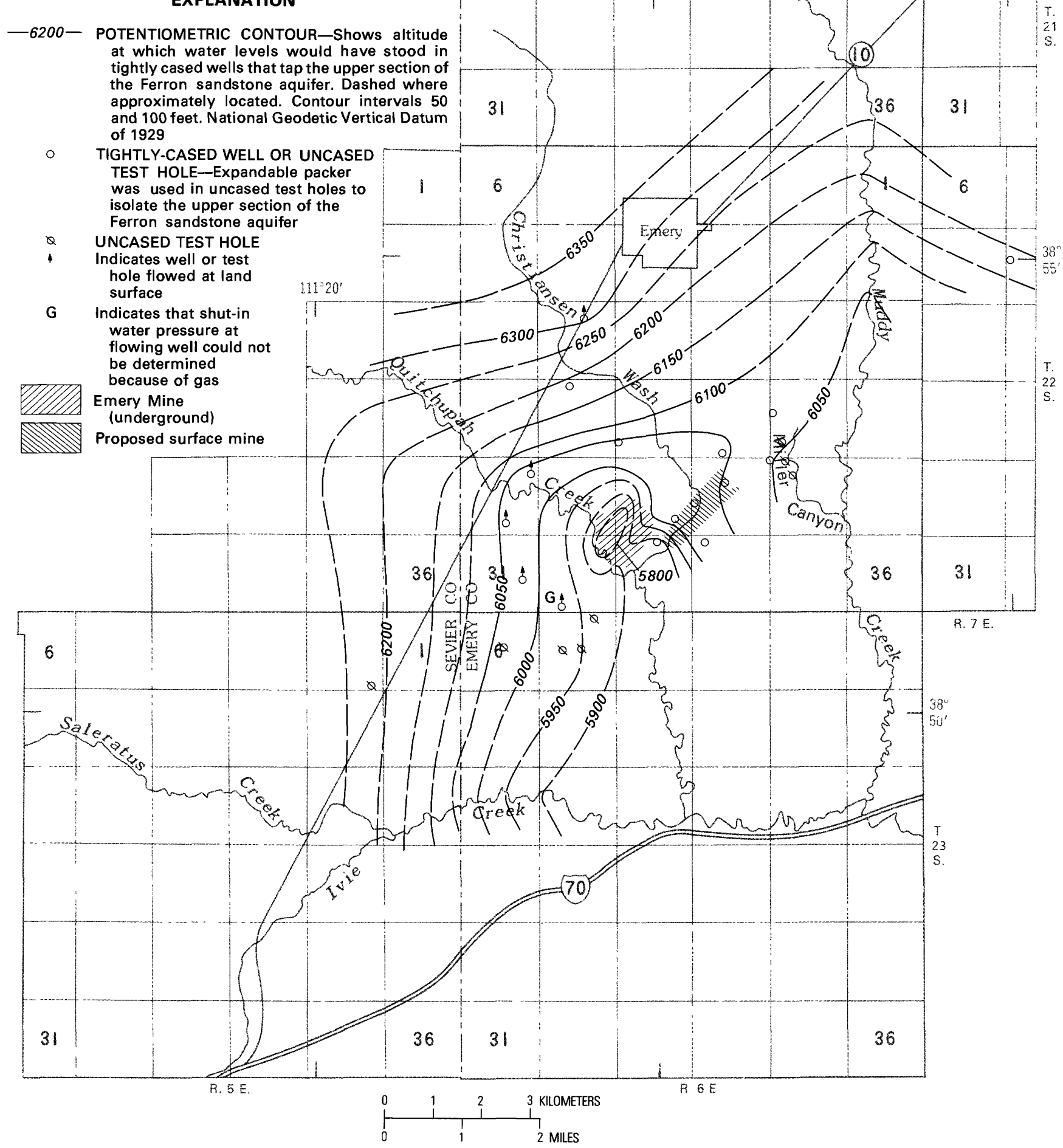

Figure 9. Potentiometric surface of the upper section of the Ferron sandstone aquifer in the Emery area, 1979.

pediment gravels and alluvium. Water-level data were available from 11 wells and test holes to define the water table. Along perennial streams and irrigation canals and at springs that issue from the Blue Gate and pediment gravels, the water table was assumed to be at the altitude of land surface. Along ephemeral streams, the water-table contours were drawn at an altitude below land surface. The water table was assumed to be within 50 feet of land surface in areas with phreatophytic growth.

No data are available to define the distribution of head in the Tununk Member which underlies the Ferron sandstone aquifer. It is believed that in those areas where 


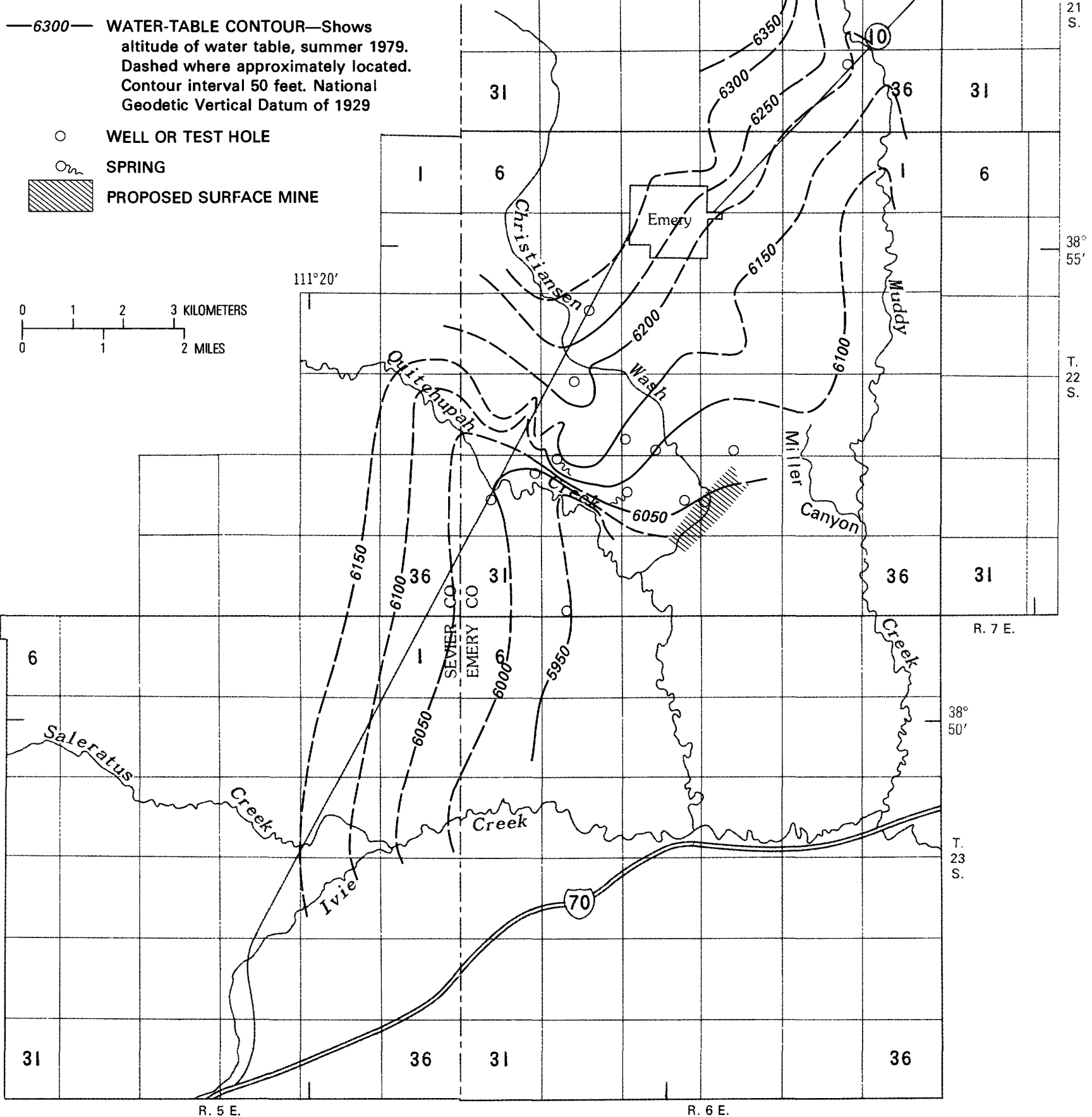

Figure 10. Configuration of the water table in rocks that overlie the Ferron sandstone aquifer in the Emery area, 1979.

head in the overlying Ferron increases with depth, head in the Tununk also increases with depth. In most areas, the potentiometric surface of the upper part of the Tununk is probably at a slightly higher altitude than the potentiometric surface of the basal Ferron. In the Ferron outcrop area, head in the aquifer decreases with depth and is probably a few feet higher than the potentiometric surface of the upper part of Tununk.

\section{Water-Level Changes}

Monitoring of water levels in the Emery area started in 1975. During the course of this study, additional observation wells were constructed, and water levels or shut-in pressures were measured monthly in 18 wells. Little water-level data exist for the years prior to 1975; thus, an evaluation of long-term changes is not possible.

Water-level hydrographs for four representative 


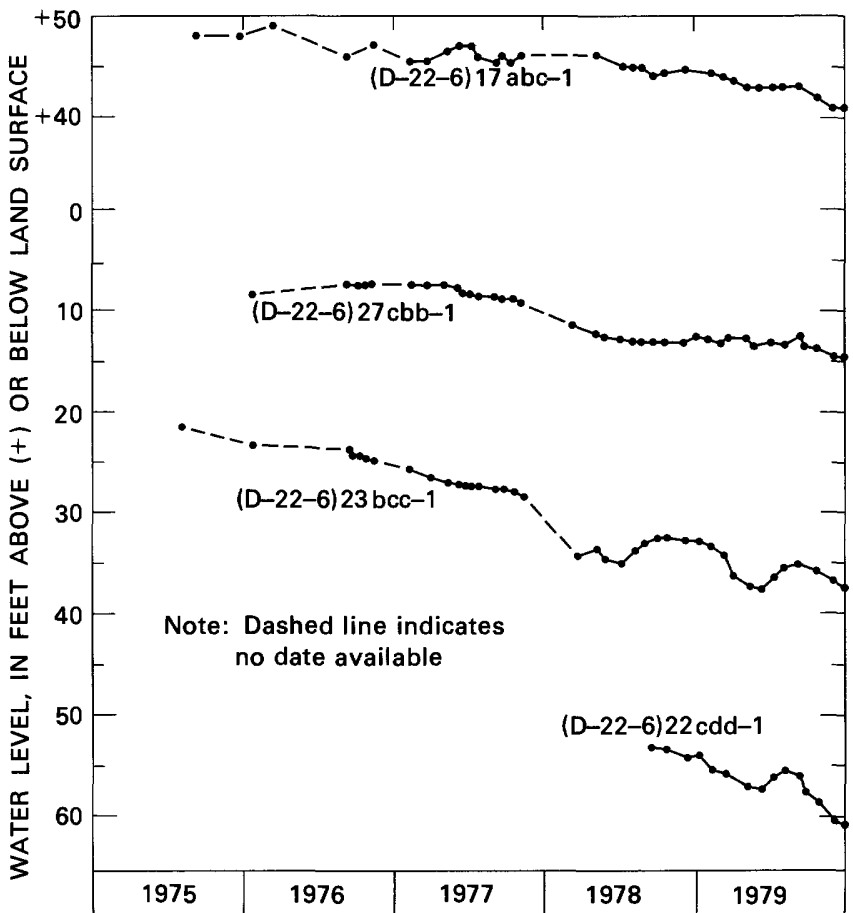

Figure 11. Water-level changes in four wells that tap the Ferron sandstone aquifer in the Emery area.

wells in the Emery area are shown in figure 11. Well (D-22-6) 17abc-1 is unused, and it taps the basal section of the Ferron sandstone aquifer. The well is about 2 miles from the Emery public-supply well, which also taps the basal section. Except for seasonal fluctuations, water pressure at the well declined from mid-1975 through 1979, with a net decline of 7 feet. When the well was drilled in May 1973, water pressure was reported as 74 feet above land surface, as contrasted to a measured water pressure of 41 feet above land surface in December 1979.

Well (D-22-6)23bcc-1 bottoms in the basal section approximately 2.5 miles from the Emery Mine. Casing perforations in the well are below the Blue Gate Member, and the well taps both the basal and upper sections of the Ferron sandstone aquifer. The net water-level decline was about 16 feet from mid- 1975 through 1979.

Well (D-22-6)27cbb-1 also bottoms in the basal section, but the top perforations in the well casing are opposite the Blue Gate Member. The well is in the proposed surface-mine area about 1 mile from the Emery Mine. Water levels in nearby wells that were constructed during this study indicate that the water level in well (D22-6) $27 \mathrm{cbb}-1$ closely approximates the altitude of the water table in the Blue Gate. From early 1976 through 1979 the water level in the well has dropped about 5 feet.

Well (D-22-6)22cdd-1 is about 0.2 mile from the northwestern edge of the proposed surface mine. The well bottoms in a shale immediately below the I- coal seam at a depth of 275 feet. The upper 100 feet of the hole was cemented around the casing to seal off water in the Blue Gate, and the water level in the well represents the potentiometric surface of the upper section of the Ferron sandstone aquifer. The water level in the well declined about 8 feet from the date of its construction in the summer of 1978 through 1979.

Precipitation at long-term U.S. Oceanic and Atmospheric Administration stations in and near Castle Valley and at rain gages installed for this study indicate that precipitation in the area between 1975 and 1979 was about 90 percent of normal and averaged about 7 inches per year in the Emery area. Below-average precipitation in the area can explain some of the declines in water levels, but most of the declines probably are due to manmade withdrawals of water from the Ferron sandstone aquifer.

\section{Movement and Age of Water}

Water moves laterally through the Ferron sandstone aquifer downgradient at approximately right angles to the potentiometric contours shown in figures 8 and 9 . On a regional scale, the strike and dip of beds in the aquifer have little effect on the movement of water. Movement of water is governed instead by the location and altitude of sources of recharge and discharge. In the Emery area, water moves through the aquifer from areas of subsurface recharge in the west and northwest toward areas of manmade discharge and toward areas of natural discharge along the Ferron outcrop.

The rate at which water moves laterally through the aquifer can be estimated from the following equation (Lohman, 1972, p. 10):

$$
V=\frac{K I}{\theta}
$$

where

$V=$ velocity, in feet per day,

$K=$ hydraulic conductivity, in feet per day,

$I=$ hydraulic gradient, a decimal fraction, and

$\theta=$ effective porosity, a decimal fraction.

Assuming a hydraulic conductivity of $1 \mathrm{ft} / \mathrm{d}$, a hydraulic gradient of $50 \mathrm{ft} / \mathrm{mi}$ or 0.0095 , an effective porosity of 5 percent, then

$$
\begin{aligned}
& V=\frac{(1 \mathrm{ft} / \mathrm{d})(0.0095)}{0.05} \\
& V=0.2 \mathrm{ft} / \mathrm{d} \text { (rounded) }
\end{aligned}
$$

It should be stressed that $0.2 \mathrm{ft} / \mathrm{d}$ would be the average fluid velocity through the aquifer at the assumed conditions. It does not necessarily equal the actual velocity between any two points in the aquifer, which would depend on the flow path followed. Water moving along an open fracture would move much faster than water moving through pore spaces between sand grains.

Water samples from the basal section of the Ferron 
sandstone aquifer were obtained from well (D-226) $17 \mathrm{abc}-1$ and Geological Survey test hole (D-23- 6)6acc1 , and carbon-14 dating of the two samples indicated ages of 28,000 and 31,000 years. Between the recharge area and sampling points, solution of carbonate rocks is a possible source of error in the dating technique. Carbonate dissolved from rocks would be depleted of the carbon- 14 radioisotope. The degree to which this process is taking place is unknown, but it is safe to assume that the dating indicates the maximum possible age.

In addition to lateral flow through the Ferron sandstone aquifer, potentiometric-surface data also indicate that significant vertical components of flow exist. Along the outcrop of the Ferron, where a small amount of recharge from precipitation occurs, water moves downward through the aquifer and some water leaks into the underlying Tununk Member. In most areas downdip from the outcrop, head in the aquifer increases with depth, and water moves upward into the Blue Gate Member.

Dewatering of the Emery Mine (the largest manmade discharge from the Ferron sandstone aquifer) has induced movement of water toward the mine from all sections of the aquifer. Most water produced from the mine has come from the upper section of the aquifer, but the potentiometric surface of the basal section also has been affected.

Two water samples were collected from seepage areas in the roof of the Emery Mine and were analyzed for concentrations of tritium (a radioisotope of hydrogen with an atomic weight of 3 ). Both samples contained detectable concentrations of tritium-12 and 21 picocuries per liter (Teledyne Isotopes, written commun., November $2,1979)$. Prior to testing of nuclear weapons in the early 1950's, natural tritium levels were about 26 picocuries per liter. Tritium levels reached a peak in the Northern Hemisphere in 1963 when concentrations in the atmosphere exceeded the natural level by approximately three orders of magnitude (Thatcher and others, 1977, p. 8). Because tritium has a half-life of only 12.33 years, some of the mine water must have been recharged to the aquifer since the early 1950 's. A number of possible sources of recharge water are Quitchupah Creek and Christiansen Wash, irrigation water applied to land overlying the mine, and precipitation on land overlying the mine.

The concentration of tritium was also determined in a water sample from well (D-22-6)31dab-1, a flowing well about 1 mile southwest of the Emery Mine. The well taps the upper section of the Ferron sandstone aquifer, and potentiometric contours (fig. 9) indicate that the well is upgradient from the mine. As might be expected, tritium concentration in the water was less than the detectable limits of 6 picocuries per liter (Teledyne Isotopes, written commun., November 2, 1979).

\section{Recharge and Discharge}

Sources of recharge to and discharge from the Ferron sandstone aquifer in the Emery area during 1979 are shown diagrammatically in figure 12 . The estimate of re-

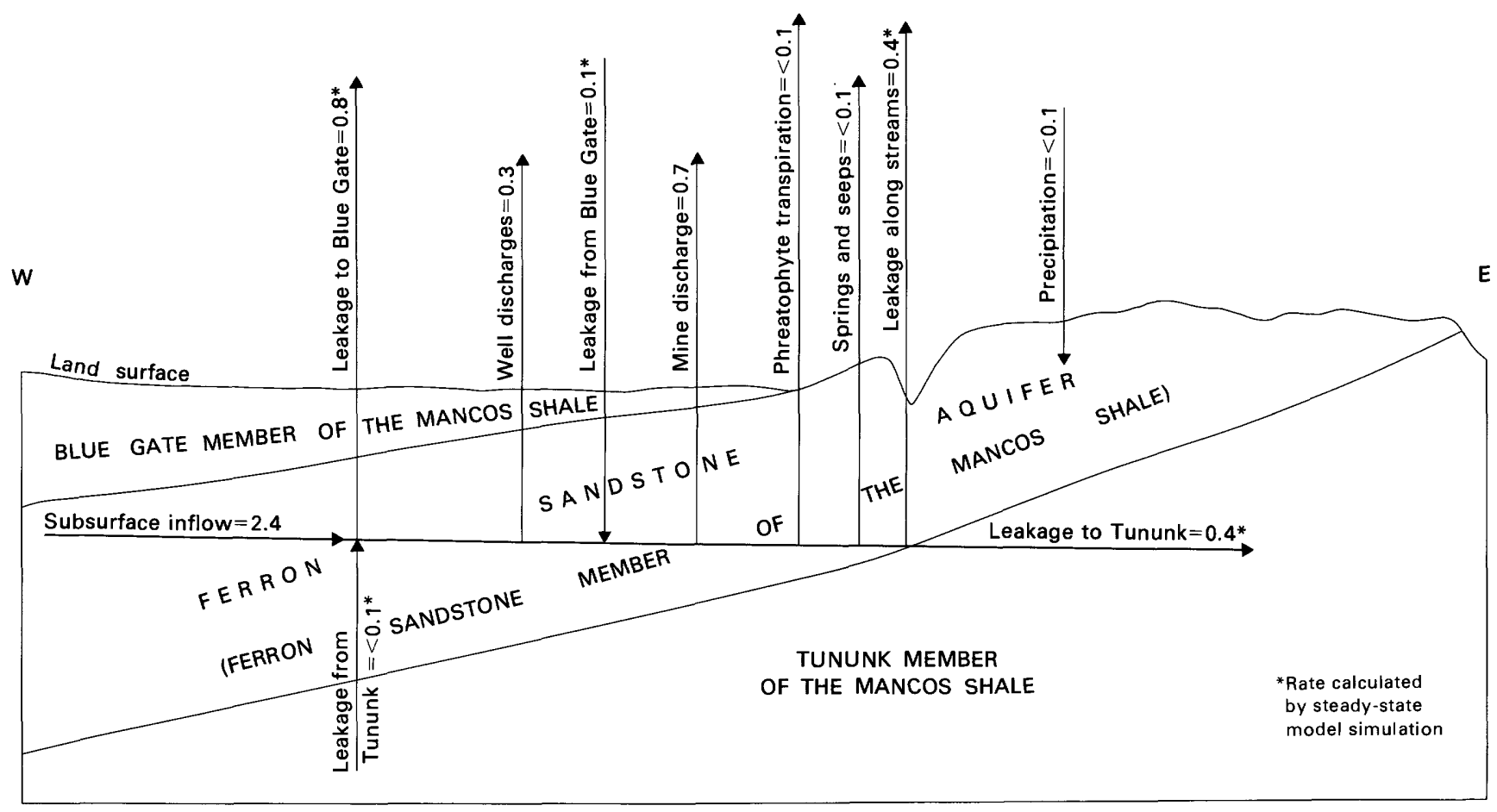

Figure 12. Diagrammatic section showing sources of recharge to and discharge from the Ferron sandstone aquifer in the Emery area, 1979. Recharge and discharge values are in cubic feet per second. 
charge and discharge shown in figure 12 indicate that discharge exceeded recharge by about $0.1 \mathrm{ft}^{3} / \mathrm{s}$; however, they are only order-of-magnitude estimates. Water-level declines in observation wells in the Emery area during 1979 indicate that the amount of storage in the aquifer declined, but the degree of imbalance between recharge and discharge is not known precisely.

\section{Subsurface Inflow}

The largest source of recharge to the Ferron sandstone aquifer in the Emery area is subsurface flow, probably from the Wasatch Plateau. Most of the water in the aquifer in the Emery area probably originates as precipitation on the plateau, and most, if not all, is transmitted into the area along the highly permeable zone along the Paradise Valley-Joes Valley fault system. Previously described carbon-14 dating indicates that movement of water from the original recharge areas to the Emery area probably takes thousands of years.

A reasonable estimate can be made of the amount of subsurface inflow to the aquifer from the west in the Emery area. Using potentiometric-surface maps (figs. 8 and 9) to determine hydraulic gradients, transmissivity developed from calibration of the computer model (Morrissey and others, 1980, fig. 5) and Darcy's law (Lohman, 1972, p. 10), subsurface inflow to the Emery area is estimated to have averaged $2.4 \mathrm{ft}^{3} / \mathrm{s}$ during 1979 or about 1,700 acre-feet per year. Data are lacking to accurately estimate subsurface inflow to the Ferron in other areas of Castle Valley.

\section{Precipitation on Outcrop Area}

Annual precipitation on the $100 \mathrm{mi}^{2}$ outcrop of the Ferron Sandstone Member in Castle Valley averages about 8 inches (U.S. Weather Bureau, 1963). Precipitation occurs about equally as rain from thunderstorms and as snow. Thunderstorms contribute little recharge because the slopes on the Ferron outcrop are usually steep, there is little or no soil cover in most of the area, and runoff is rapid. Most of what little recharge occurs on the outcrop area probably takes place during the spring when snow melts slowly.

In those areas of the lower Dirty Devil River basin where annual precipitation averages less than 12 inches, Hood and Danielson (1979, table 4) estimate that recharge to bedrock aquifers averages, at most, 0.5 percent of precipitation. This is also probably the maximum amount that could be recharged on the Ferron outcrop, and it amounts to only about 200 acre-feet per year for the entire 100 $\mathrm{mi}^{2}$ of outcrop area in Castle Valley.

The Ferron outcrop, particularly in the southern part of Castle Valley, is deeply cut by stream channels as shown in figure 3 . Much of the water that recharges the aquifer in the outcrop is discharged close to the recharge areas by leakage to the underlying Tununk Member and by leakage to alluvium along streams. In most areas, little or no recharge from the outcrop area reaches the main body of the aquifer downdip from the outcrop.

The Ferron sandstone aquifer in the Cleveland, Elmo, and Wellington areas (the Clawson and Washboard units of Cotter) is separated from the main body of the Ferron that underlies the Wasatch Plateau and Castle Valley to the south. (See figure 5.) Unlike the Emery area, recharge to the aquifer in these areas may be limited to a small amount of recharge on the narrow strip of Ferron outcrop.

\section{Leakage}

The Ferron sandstone aquifer lies between relatively impermeable shales in the Blue Gate and Tununk Members, but there is some movement of water between these three zones. In most of the Emery area downdip from the Ferron outcrop, heads in the aquifer are usually higher than the water table in overlying rocks, and there is upward leakage of water into the Blue Gate. Much of the water in the overlying Blue Gate is consumed by greasewood (Sarcobatus vermiculatus), a phreatophyte. Computations using the three-dimensional digital-computer model of the Ferron sandstone aquifer indicate that upward leakage from the Ferron into the Blue Gate averaged about $0.8 \mathrm{ft}^{3} / \mathrm{s}$ during 1979 , or about 600 acre-feet per year in the Emery area (Morrissey and others, 1980, fig. 2).

It should be noted that records of many wells and test holes drilled in Castle Valley indicate that the shale in the Blue Gate Member is "dry." In most cases, the use of the term "dry" refers to the lack of water production when drilling and does not indicate that the shale was unsaturated. Test holes (D-22-6)27cbb-4 and 6 bottom in the Blue Gate in the proposed surface-mine area. Both holes were drilled with an air-rotary drilling rig, and shale cuttings appeared dry when drilling. The test holes contained no water between the time drilling ceased and the holes were cased, but over a period of several days both holes partly filled with water to the approximate level of the water table.

Near the Emery Mine, the potentiometric surface of the upper section of the Ferron sandstone aquifer has been lowered to a level below the water table in the Blue Gate Member by mine dewatering. This is the only area near Emery where water-level data indicate that water in the Blue Gate was leaking into the Ferron during 1979. Computations using the computer model indicate that leakage from the Blue Gate to the Ferron near the Emery Mine averaged about $0.1 \mathrm{ft}^{3} / \mathrm{s}$ during 1979 , or about 70 acre-feet per year.

Along the Paradise Valley-Joes Valley fault system, hydraulic connection between the Blue Gate and Ferron sandstone aquifer probably has been increased by fractur- 
ing. Well (D-22-6)19cdb-1 bottoms in the Blue Gate approximately 300 feet above the Ferron, and the well had a sustained flow of $20 \mathrm{gal} / \mathrm{min}$ during the summer of 1979 . The dissolved-solids concentration in the water was 808 $\mathrm{mg} / \mathrm{L}$ (table 6) and was typical of water from the Ferron and not the Blue Gate. It is believed that when the well is allowed to flow, most of the water is actually derived from the Ferron, although it has probably moved freely through fractures into the Blue Gate.

Head in the underlying Tununk Member and the direction of water movement between the Tununk and Ferron sandstone aquifer are unknown. It is probably safe to assume that downdip from the Ferron outcrop and away from major manmade sources of discharge from the Ferron, the exchange of water between the two units is negligible. Computations using the computer model indicate that during 1979 in the Emery area less than $0.1 \mathrm{ft}^{3} / \mathrm{s}$ (less than 70 acre-feet) probably leaked upward into the Ferron from the Tununk, all in areas downdip from the Ferron outcrop.

In much of the outcrop area of the Ferron near Emery, heads in the Ferron sandstone aquifer decrease with depth. Water probably leaks from the Ferron into alluvium in the bottoms of the deeply incised stream canyons and into the underlying shales of the Tununk. Much of the water in the alluvium is consumed by phreatophytes, mainly greasewood. Most of the water that leaks into the Tununk evaporates on the barren shale slopes beneath the Ferron outcrop where salt accumulates through summer and fall. (See figure 13.) Computations using the computer model indicate that during 1979 in the Emery area leakage to alluvium along streams and leakage to the Tununk each probably averaged about 0.4 $\mathrm{ft}^{3} / \mathrm{s}$.

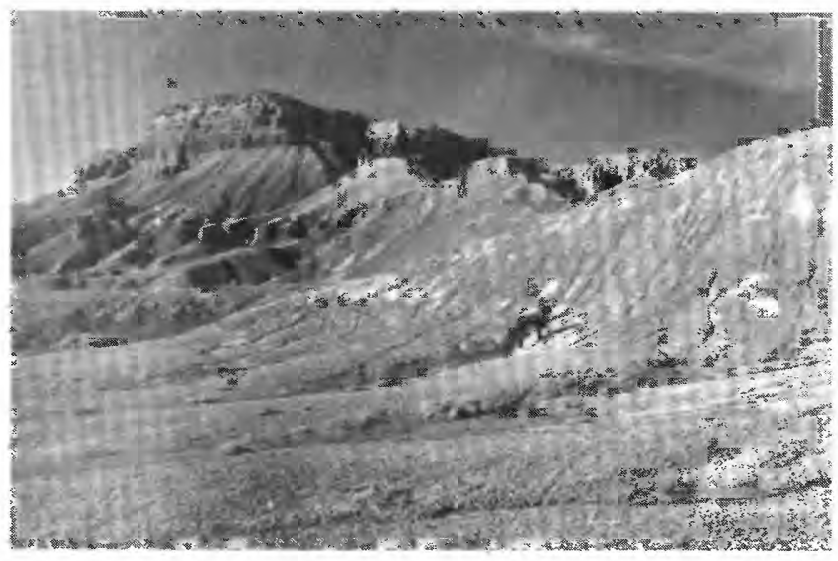

Figure 13. Salt on the barren shale slopes of the Tununk Member of the Mancos Shale where ground water has evaporated. Overlying Ferron Sandstone Member of the Mancos Shale and Coal Cliffs in background. View facing southwest.

\section{Transpiration of Phreatophytes}

Although many areas in Castle Valley support dense phreatophyte growth, few phreatophytes obtain water directly from the Ferron sandstone aquifer. Most phreatophytes in Castle Valley obtain water from alluvium along streams and from the shallow saturated zone in the Blue Gate Member. Phreatophyte growth on the Ferron outcrop is limited by the depth to water and poor soil conditions. The few phreatophytes (mainly greasewood) that obtain water from the Ferron grow along a narrow strip about 0.2 mile wide east of the contact between the Ferron and the Blue Gate. Depth to the saturated zone in this area is less than about 50 feet.

Approximately 440 acres of sparse phreatophyte growth on the Ferron outcrop in the Emery area was mapped using aerial photographs. Using a method by Criddle, Harris, and Willardson (1962, p. 12 and 13), transpiration of water directly from the Ferron in the Emery area during 1979 is estimated to have averaged $0.04 \mathrm{ft}^{3} / \mathrm{s}$ (about 30 acre-feet per year).

\section{Springs and Seeps}

Numerous seeps issue from the Ferron sandstone aquifer in Castle Valley, but only four springs were found with discernible flows. Springs (D-22-6)23dda-SI, (D23-6) $17 \mathrm{dba}-\mathrm{S} 1$, and (D-24-5) 13bcd-S1 all issue from the basal section of the Ferron near the contact with the Tununk Member along Muddy Creek, Ivie Creek, and Willow Springs Wash. The fourth spring, (D-22-6)23cdcS1, issues from the upper section of the Ferron at the head of Miller Canyon near the contact with the Blue Gate Member. Records for these springs and chemical analyses of the water, where available, are listed in tables 5 and 6 . Continuous-discharge records at springs are not available, and it is difficult to estimate the water discharged,through the seeps. The discharge of springs and seeps issuing from the Ferron in Castle Valley, however, probably does not exceed $0.2 \mathrm{ft}^{3} / \mathrm{s}$, or about 140 acre-feet per year. In the Emery area, the combined discharge of springs and seeps from the Ferron is probably about half this amount.

Lupton (1916, p. 16) described a spring that issued from the Ferron at the head of Short Canyon in the SW $1 / 4$ 'sec. 24, T. 21 S., R. 7 E., and that supplied "sufficient excellent water for a few head of stock the year round." This site was visited in June 1978 and November 1979. An empty stock-watering tank was found, but no spring flow was observed.

\section{Well Discharges}

During 1979 in Castle Valley, 18 wells tapped the Ferron sandstone aquifer for purposes other than hydrologic testing. Water from the Ferron was used for public 
supply in the town of Emery, coal washing, stock watering, a small amount of irrigation, and domestic supply at three ranches.

Records from a meter on the discharge line of the Emery municipal well, (D-22-6)4cab-1, indicate that the discharge averaged $0.2 \mathrm{ft}^{3} / \mathrm{s}$ during 1979. Three wells were used for coal washing at the Dog Valley Mine in T. $23 \mathrm{~S}$., R. $6 \mathrm{E}$, , and the total discharge averaged about $0.04 \mathrm{ft}^{3} / \mathrm{s}$ during 10 months of operation in 1979 (Western States Minerals Corp., written commun., February 14, 1980). Discharge from the remainder of the Ferron wells in Castle Valley averaged about $0.07 \mathrm{ft}^{3} / \mathrm{s}$.

\section{Mine Dewatering}

Dewatering of the underground Emery Mine was the largest source of manmade discharge from the Ferron sandstone aquifer in Castle Valley during 1979. From discharge measurements at the end of the mine-discharge line and pumping time furnished by Consolidation Coal Co., mine pumpage is estimated to have averaged $0.6 \mathrm{ft}^{3} / \mathrm{s}$ during 1979. An additional $0.1 \mathrm{ft}^{3} / \mathrm{s}$ is estimated to have been removed from the mine for showers and by evaporation.

Discharge from the mine increased during 1979. The discharge averaged about $0.5 \mathrm{ft}^{3} / \mathrm{s}$ during January 1-July $19,0.6 \mathrm{ft}^{3} / \mathrm{s}$ during July 20 -October $8,0.8 \mathrm{ft}^{3} / \mathrm{s}$ during October 9-November 1 , and $0.7 \mathrm{ft}^{3} / \mathrm{s}$ during the remainder of the year. As the underground mining progresses toward the Paradise Valley-Joes Valley fault system into areas with higher aquifer transmissivity, mine dewatering should increase.

\section{Availability of Water}

The largest quantities of water are available from the Ferron sandstone aquifer within about 2 miles of the Paradise Valley-Joes Valley fault system in the Emery area. In this area, the aquifer transmissivity has been increased by fracturing, and several wells have been constructed that are capable of producing more than $100 \mathrm{gal} /$ min. (See wells (D-22-6) $4 \mathrm{cab}-1$ and 2, 17abc-1, 30dcb1 , and 31 dab-1 in table 5.) Most of the wells in this area flow naturally at land surface at rates less than 100 $\mathrm{gal} / \mathrm{min}$, but discharges could be increased by pumping. Wells that fully penetrate the aquifer in this area could be expected to produce 100 to $500 \mathrm{gal} / \mathrm{min}$ if pumped.

Elsewhere in the Emery area and farther south in Castle Valley, individual wells could be expected to produce 10 to $50 \mathrm{gal} / \mathrm{min}$ from the Ferron sandstone aquifer. Yields would be greatest from fully penetrating wells in areas with the greatest saturated thickness and transmissivity. Saturated thickness and transmissivity decrease in the outcrop area of the Ferron. Wells within about 1 mile of the contact with the underlying Tununk Member probably would yield less than $10 \mathrm{gal} / \mathrm{min}$.

In the northern two-thirds of Castle Valley, several miles from major faulting and where the Ferron is less than 300 feet thick, yields of individual wells that tap the Ferron probably would not exceed $10 \mathrm{gal} / \mathrm{min}$. As pointed out earlier, the Ferron sandstone aquifer in the Cleveland, Elmo, and Wellington areas is separated from the main body of the Ferron that underlies the Wasatch Plateau and Castle Valley to the south. Unlike the Emery area, recharge to the aquifer in the northern part of Castle Valley may be limited to a small amount of recharge from precipitation on the narrow strip of Ferron outcrop. Well (D17-10)4bba-1 reportedly penetrates the Ferron about 0.5 mile south of Elmo, and the driller reported that no water was encountered. About 3 miles farther south, well (D17-10)16dda-1 taps the Ferron and produces enough water for one household.

\section{Quality of Water}

Chemical analyses of water from wells, test holes, springs and the Emery Mine in Castle Valley are listed in table 6.

As shown in figures 14 and 15 , the concentration of dissolved solids in water from the Ferron sandstone aquifer in the Emery area increases eastward from the Paradise Valley-Joes Valley fault system toward the Ferron outcrop. Comparison of figures 14 and 15 indicates that in most areas dissolved-solids concentrations also increase upward in the aquifer.

In the Emery area, deterioration of water quality in the Ferron sandstone aquifer usually is due to increased concentrations of dissolved sodium and sulfate. Shales in the Mancos Shale contain large quantities of soluble sodium-sulfate minerals such as mirabilite $\left(\mathrm{Na}_{2} \mathrm{SO}_{4} \cdot 10 \mathrm{H}_{2} \mathrm{O}\right)$ and thenardite $\left(\mathrm{Na}_{2} \mathrm{SO}_{4}\right)$ (Waddell and others, 1979). Dissolved-solids concentrations generally increase with increased time that water is in storage in the aquifer and in contact with the shales.

The largest observed concentration of dissolved solids in the upper section of the Ferron sandstone aquifer east of the Paradise Valley-Joes Valley fault system were in an area near the proposed surface mine, between the Emery Mine and the head of Miller Canyon. During 1979 in this area, the water table in the Blue Gate Member was at a higher altitude than the potentiometric surface of the upper section of the Ferron. Water in the Blue Gate, which contained about $20,000 \mathrm{mg} / \mathrm{L}$ of dissolved solids, was leaking downward into the Ferron. The downward leakage of saline water from the Blue Gate in this area could be induced by natural discharge from the aquifer at the head of Miller Canyon, or it could be due to dewatering of the Emery Mine. 


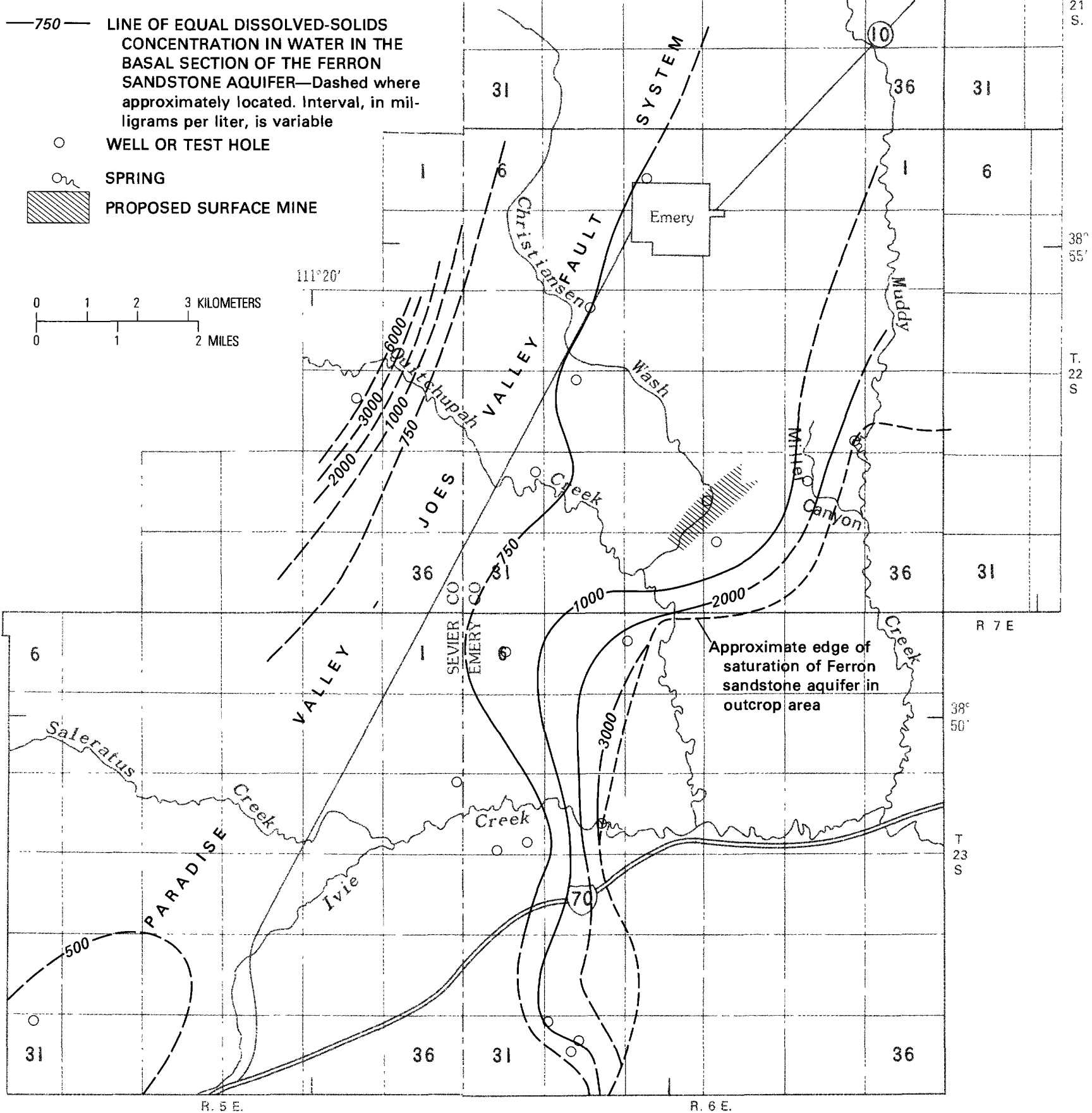

Figure 14. Concentration of dissolved solids in water in the basal section of the Ferron sandstone aquifer in the Emery area, 1979.

From the configuration of the contours in figure 15 , it can be inferred that the removal of large quantities of water from the Emery Mine has improved water quality in the upper section of the Ferron between the mine and the fault system to the west. Dewatering of the mine has accelerated the rate of water movement toward the mine from all directions. The increased movement of less saline water from the west through the upper section of the aquifer, however, has more than offset any deterioration of water quality that may have been caused by increased downward leakage from the Blue Gate. Improvement in the quality of water entering the mine also may be indicated by changes in dissolved-solids concentrations in water pumped from the mine. Water collected in 1975 at the end of the mine discharge line contained 5,100 $\mathrm{mg} / \mathrm{L}$ of dissolved solids (Waddell and others, 1978, p. 


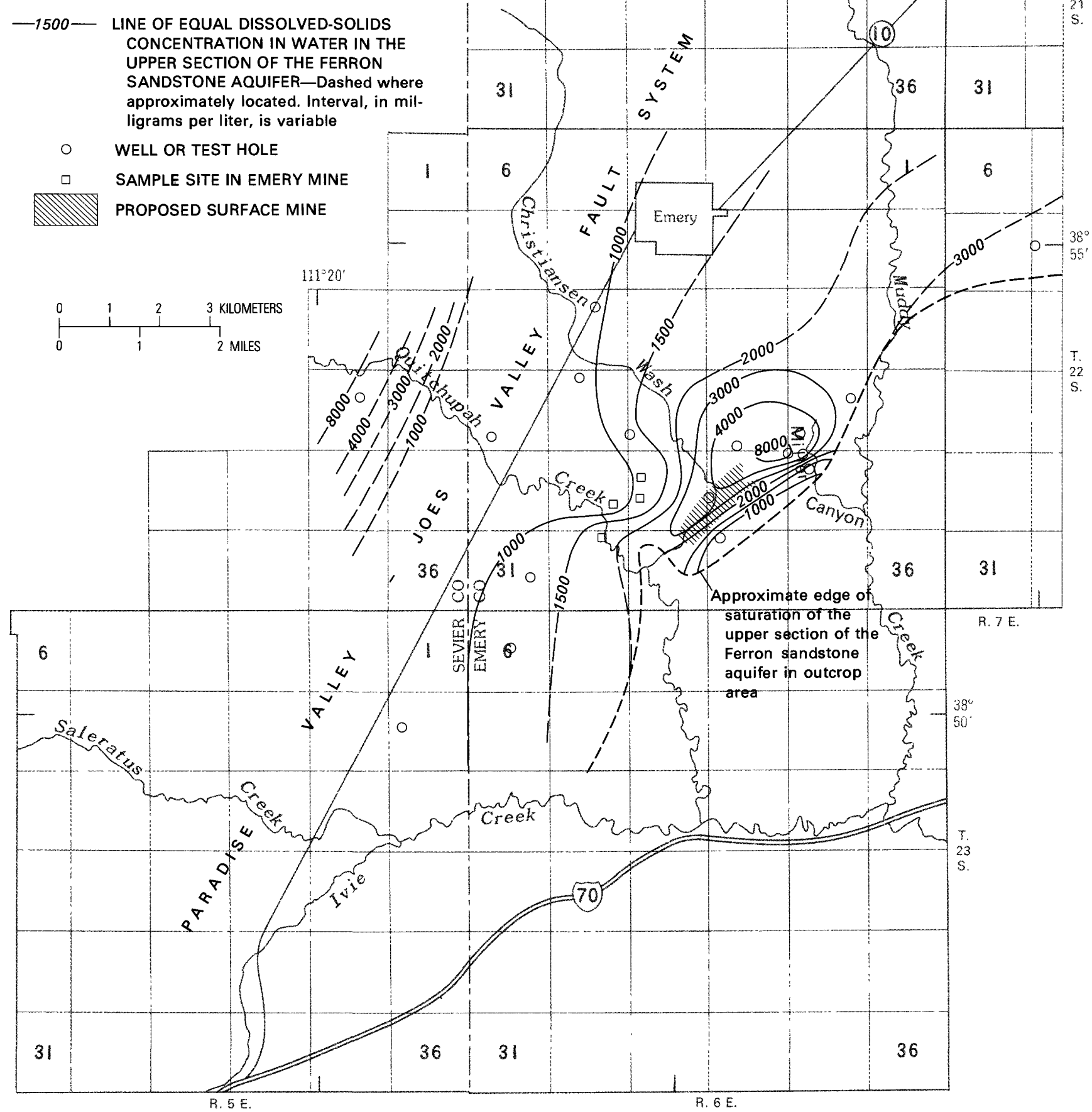

Figure 15. Concentration of dissolved solids in water in the upper section of the Ferron sandstone aquifer in the Emery area, 1979.

15). Samples collected in February and September 1979 contained 4,780 and 3,040 $\mathrm{mg} / \mathrm{L}$ of dissolved solids.

Data are lacking to define water quality in the Ferron sandstone aquifer in most areas west of the Paradise Valley-Joes Valley fault system. However, large dissolved-solids concentrations in water from test hole (D-225) $23 \mathrm{aca}-1$ indicate that water quality in the Ferron deteriorates, at least in some areas, a short distance west of the fault system. This is consistent with the hypothesis that most, if not all, of the water moving from the Wasatch Plateau to the Ferron in the Emery area is transmitted along the highly permeable zone created by faulting.

The few chemical analyses of water from the Ferron in the northern two-thirds of Castle Valley and adjacent Wasatch Plateau (table 6) indicate that water is generally 
of poorer quality than in most of the Emery area. This is probably due to the increased distance from recharge areas and the increased time water is in contact with the rocks. Dissolved-solids concentrations in water in the Ferron in the northern two-thirds of Castle Valley usually exceed $3,000 \mathrm{mg} / \mathrm{L}$. Several water samples obtained from test holes and gas wells in the Ferron contained more than $10,000 \mathrm{mg} / \mathrm{L}$ of chloride and more than $20,000 \mathrm{mg} / \mathrm{L}$ of dissolved solids.

\section{SURFACE WATER}

The northern and central parts of Castle Valley are drained by the Price and San Rafael Rivers, both of which are tributaries to the Green River. Three major tributaries to the San Rafael River (Huntington, Ferron, and Cottonwood Creeks) originate on the central Wasatch Plateau and cross Castle Valley and the outcrop of the Ferron Sandstone Member. The flows of these streams are diverted in Castle Valley for irrigation or municipal supply.

The southern part of Castle Valley is drained by tributaries to the Dirty Devil River, which is a tributary to the Colorado River. Three major tributaries to the Dirty Devil River that originate on the Wasatch Plateau and that cross the outcrop of the Ferron Sandstone Member are Muddy, Quitchupah, and Ivie Creeks.

Quitchupah Creek and its tributary Christiansen Wash are treated in detail in this report because they are near the proposed surface mine. Figure 16 shows data-collection sites on these streams during 1978-79. For information on other surface waters in the area, the reader is referred to Mundorff (1972 and 1979) and Waddell, Contratto, Sumsion, and Butler (1979).

\section{Quantity}

Quitchupah Creek has a drainage area of $104 \mathrm{mi}^{2}$ at gaging station 09331900 near the Emery Mine. The average daily discharge for water year 1979, the first complete year of operation, was $6.7 \mathrm{ft}^{3} / \mathrm{s}$, ranging from a low of $1.1 \mathrm{ft}^{3} / \mathrm{s}$ on October $28-30,1978$, to a high of 45 $\mathrm{ft}^{3} / \mathrm{s}$ on November 2, 1978 (U.S. Geological Survey, 1980 , p. 290). During the summer months, flow at the station consists mainly of water pumped from the Emery Mine and return flow of irrigation water.

Christiansen Wash was gaged at station 09331950 during the 1979 water year. The drainage area at this station, a short distance downstream from the proposed surface mine, is $13.6 \mathrm{mi}^{2}$. Daily discharge at the station averaged $2.8 \mathrm{ft}^{3} / \mathrm{s}$ during water year 1979 , ranging from 0.43 $\mathrm{ft}^{3} / \mathrm{s}$ on January 7,1979 , to $20 \mathrm{ft}^{3} / \mathrm{s}$ on May 6 and 20 , 1979 (U.S. Geological Survey, 1980, p. 294). The flow in Christiansen Wash is perennial at the gaging station, and streamflow is due mainly to return flow of irrigation water originally diverted from Muddy Creek. The upper reaches of Christiansen Wash, upstream from irrigated areas, flow only in response to snowmelt or thunderstorms.

\section{Quality}

\section{Inorganic Dissolved Solids}

Most surface waters in Castle Valley deteriorate in chemical quality as they cross shales in the Blue Gate Member (Mundorff, 1979, p. 34). As previously mentioned, the shales contain large quantities of soluble sodium and sulfate minerals. These minerals are subject to solution by surface runoff and ground water.

Water in Quitchupah Creek deteriorates in chemical quality between State Highway 10 and the confluence with Christiansen Wash. At State Highway 10, during 197576 , the average concentration of dissolved solids in six water samples was $950 \mathrm{mg} / \mathrm{L}$. The average concentration in six samples collected concurrently from Quitchupah Creek just above the confluence with Christiansen Wash was $2,270 \mathrm{mg} / \mathrm{L}$ (Mundorff, 1979, table 6). This increase in dissolved-solids concentration is due to increased concentrations of all the major cations and anions but mostly to an increase in sodium and sulfate. Inflow between the two sites mainly consisted of pumpage from the Emery Mine and return flow of irrigation water.

Seasonal variation in the concentration of dissolved solids at the gaging station on Quitchupah Creek during the 1979 water year is illustrated in figure 17. Observed extremes of dissolved-solids concentrations were 696 $\mathrm{mg} / \mathrm{L}$ on May 8,1979 , and $3,960 \mathrm{mg} / \mathrm{L}$ on November 19 , 1978 (U.S. Geological Survey, 1980, p. 292). The trend during the 1979 water year was from greater discharge and lesser concentration of dissolved solids during the spring-runoff period (April-June) to lesser discharge and greater concentration of dissolved solids during the summer and fall (July-November). During the winter (December-March), discharge and concentration of dissolved solids generally were intermediate to those observed during the spring and summer.

Areal variation in the concentration of dissolved solids along Christiansen Wash is slightly different than along Quitchupah Creek. The average concentration of dissolved solids in six sets of samples collected during 1975-76 at State Highway 10 and at the mouth of Christiansen Wash were 3,470 and 2,610 mg/L (Mundorff, 1978, table 6), indicating a downstream decrease in the concentration of dissolved solids. Flow in Christiansen Wash at State Highway 10 is intermittent and, with the exception of periods during thunderstorms and snowmelt, consists of seepage of irrigation water that contains large concentrations of dissolved solids. A part of the flow of Christiansen Wash at the mouth also consists of irrigation water returned by ground-water seepage, but the flow is also 
CONTINUOUS-RECORD GAGING STATION-Eight-digit number identifies station (first two digits identify the stream as being in the Colorado River Basin and the six remaining digits indicate relative downstream order)

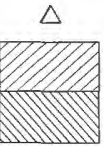

DISCHARGE-MEASUREMENT SITE

EMERY MINE (underground)

PROPOSED SURFACE MINE

Letter by symbol indicated other types of data collected

$B$, benthic invertebrates

$C$, inorganic chemical analysis

S, suspended sediment
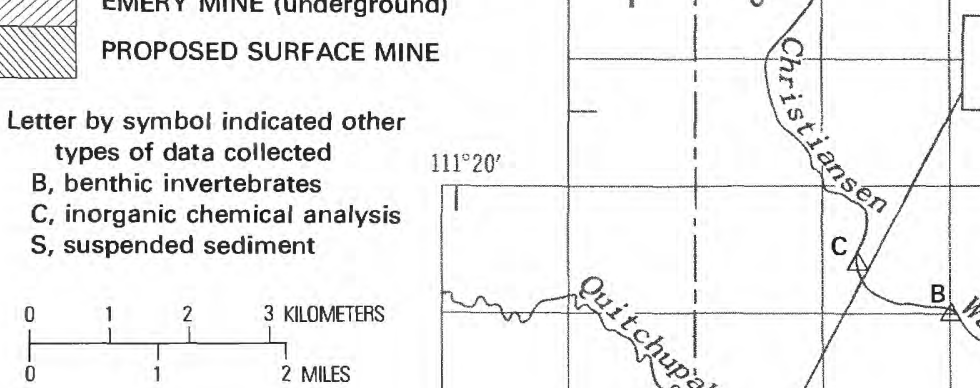

$111^{\circ} 15^{\prime}$

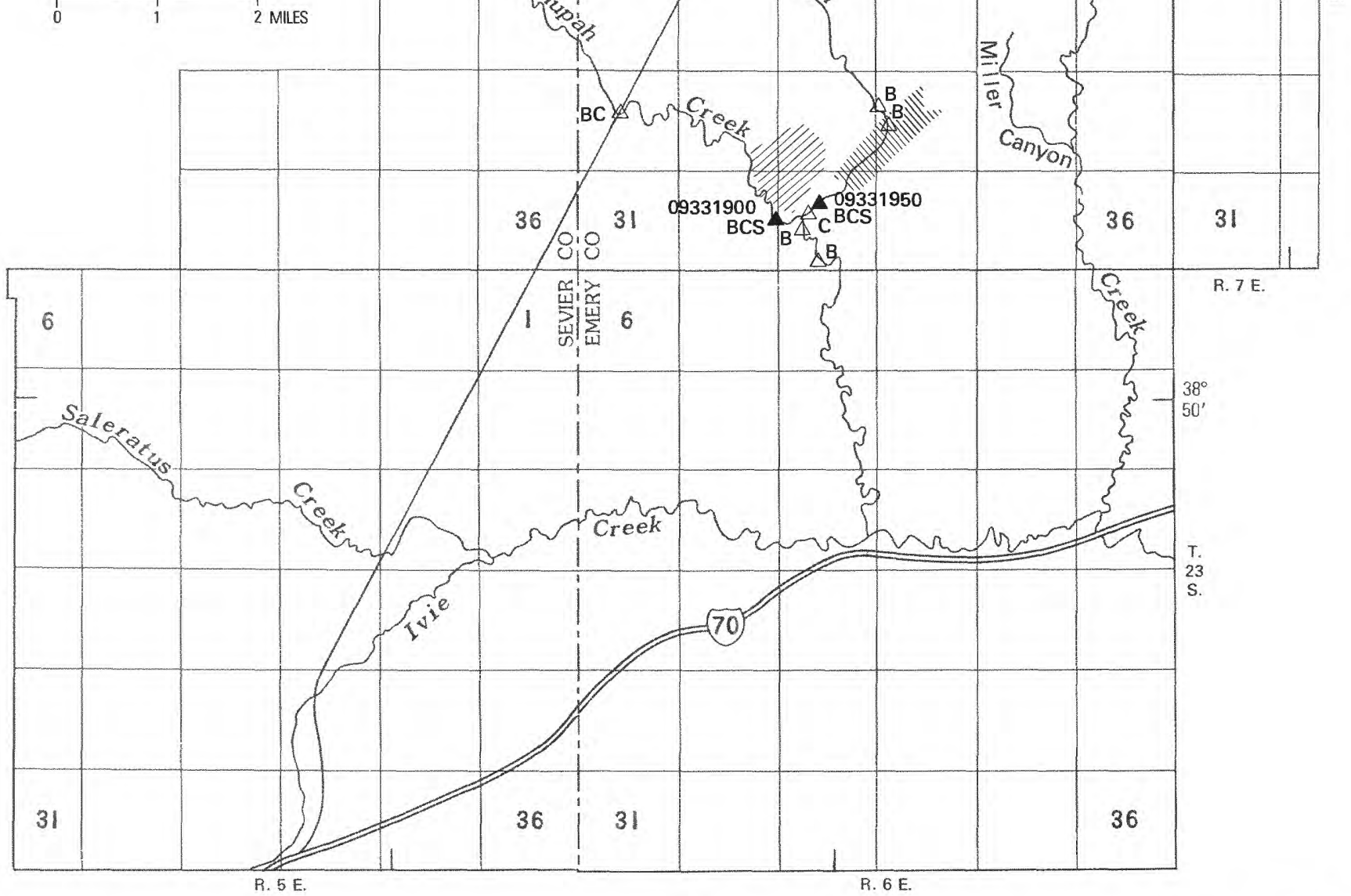

Figure 16. Location of data-collection sites on Quitchupah Creek and Christiansen Wash in the Emery area, 1978-79.

sustained by overland flow of irrigation water and water discharged from the Ferron sandstone aquifer. The major part of the flow at the mouth probably represents overland flow of irrigation water, which generally contains smaller concentrations of dissolved solids than does ground water that seeps into the Wash.

The average concentration of dissolved solids of 12 monthly samples collected at the gaging station on Christ- iansen Wash during the 1979 water year was $2,380 \mathrm{mg} / \mathrm{L}$. Observed extremes of dissolved solids were $582 \mathrm{mg} / \mathrm{L}$ on April 18, 1979, and 4,470 mg/L on February 18, 1979 (U.S. Geological Survey, 1980, p. 296). The predominant cation and anion in the water were sodium and sulfate, and the $\mathrm{pH}$ ranged from 8.1 to 8.5 .

Seasonal variations of discharge and concentration of dissolved solids in Christiansen Wash also are shown 


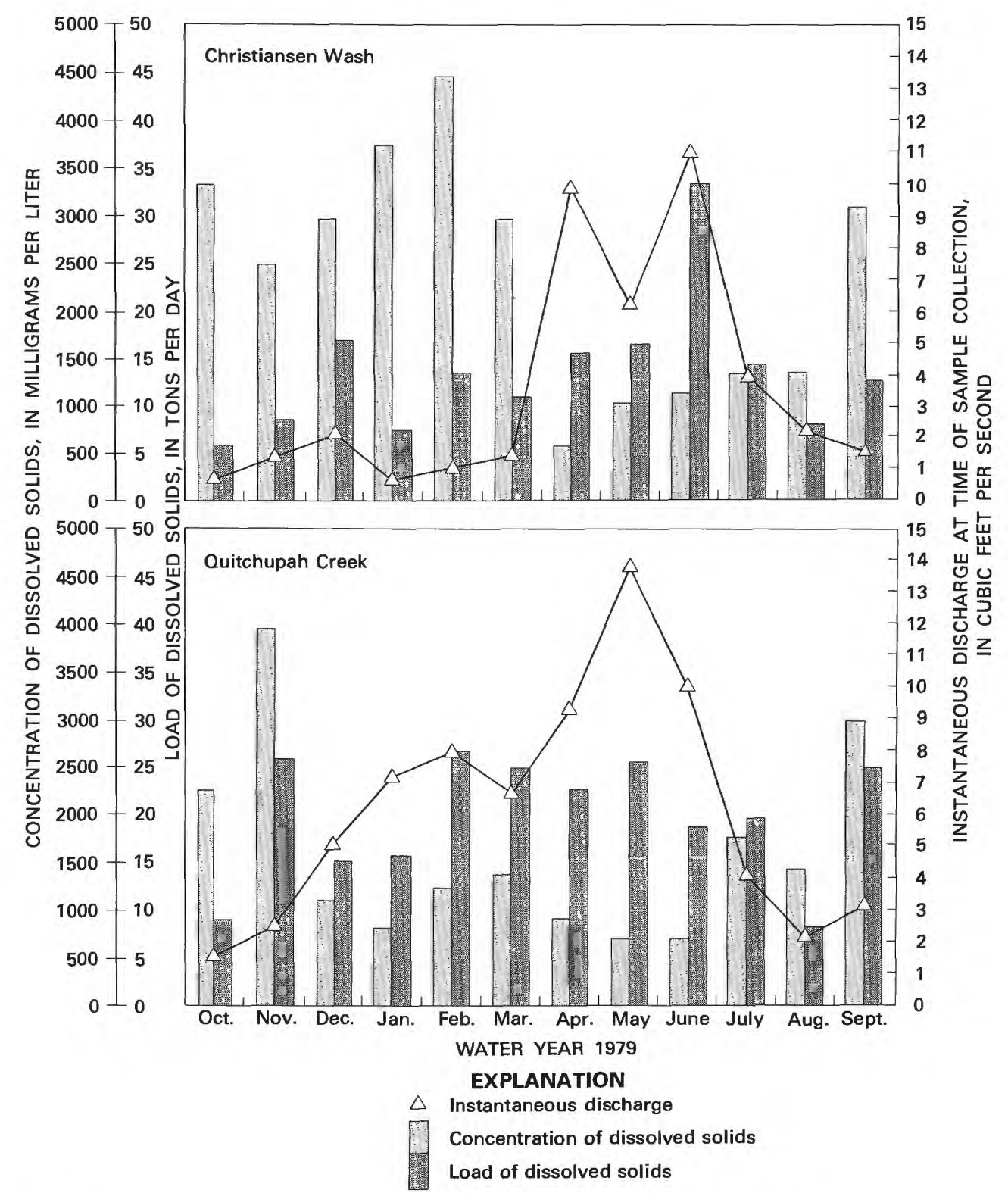

Figure 17. Monthly variation in the concentration and load of dissolved solids at gaging stations 09331900 and 09331950 on Quitchupah Creek and Christiansen Wash in the Emery area, water year 1979.

in figure 17. During winter when there is no irrigation, discharge decreases, and the streamflow is supported mainly by ground-water seepage, which has a relatively large concentration of dissolved solids. During spring and early summer, discharge increases and concentrations of dissolved solids are smallest.

\section{Suspended Sediment}

Suspended-sediment samples were collected at the gaging stations on Christiansen Wash and Quitchupah Creek by the equal-discharge increment and equal-width increment methods (Guy and others, 1977, chap. 3). During August 2, 1978, to September 17, 1979, the observed suspended-sediment concentration at the gaging station on Quitchupah Creek ranged from 111 to $30,200 \mathrm{mg} / \mathrm{L}$. The relationship between suspended-sediment concentration and stream discharge at the Quitchupah station is shown in figure 18. As discharge increased, the concentration of suspended sediment also increased. It is interesting to note that there is less scatter from the regression line at discharges above $5 \mathrm{ft}^{3} / \mathrm{s}$. The correlation coefficient ${ }^{6}$ for the regression line in figure 18 is 0.88 .

\footnotetext{
${ }^{6}$ Correlation coefficient is an estimate of the degree of interrelation between variables and is expressed in dimensionless units. A correlation of $+I$ indicates a perfect direct relationship between two varables; a correlation of -1 indicates that one variable changes inversely with relation to the other. Between the two extremes is a spectrum of less-than-perfect relationships, including zero, which indicates the lack of any sort of linear relationship.
} 


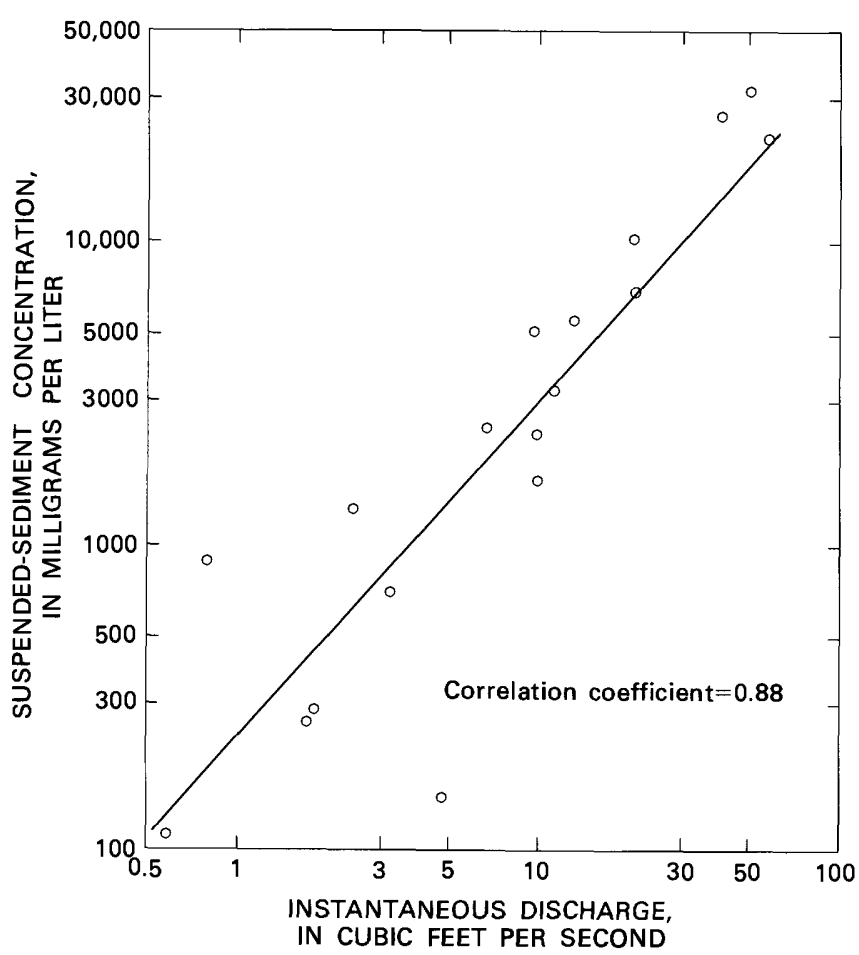

Figure 18. Relationship between suspended-sediment concentration and stream discharge at gaging station 09331900 on Quitchupah Creek in the Emery area, August 1978-September 1979.

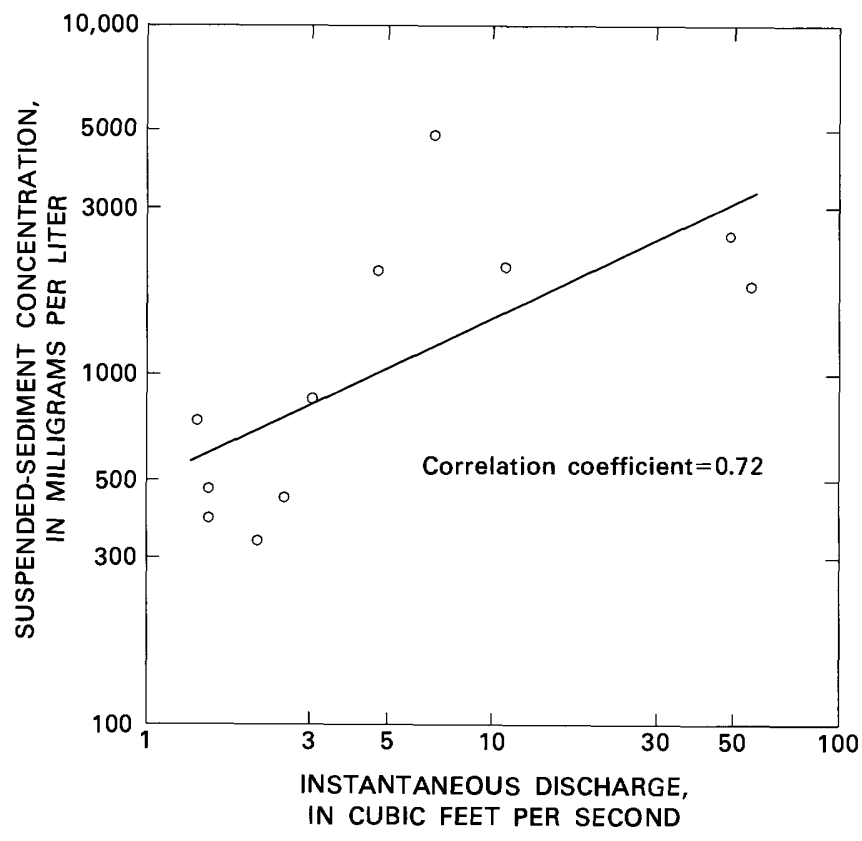

Figure 19. Relationship between suspended-sediment concentration and stream discharge at gaging station 09331950 on Christiansen Wash in the Emery area, May 1978-September 1979.

During May 25, 1978, to September 17, 1979, the observed suspended-sediment concentration at the gaging station on Christiansen Wash ranged from 3 to $4,870 \mathrm{mg} / \mathrm{L}$.
The relationship between suspended-sediment concentration and discharge at the Christiansen Wash station for discharges greater than $1 \mathrm{ft}^{3} / \mathrm{s}$ is shown in figure 19. This relationship is not as well defined as at Quitchupah Creek. The regression line in figure 19, which applies to observed discharges that were greater than $1 \mathrm{ft}^{3} / \mathrm{s}$, has a correlation coefficient of 0.72 . The regression lines in figures 18 and 19 should not be used to estimate suspended-sediment concentrations for discharges outside the ranges that were sampled.

Sediment data at the gages on Christiansen Wash and Quitchupah Creek are insufficient to determine sediment yields from the basins. King and Mace (1953, p. 18) studied sedimentation in a number of small reservoirs in Castle Valley, and they found that the average annual production varied from $0.3 \mathrm{acre}-\mathrm{ft} / \mathrm{mi}^{2}$ in areas underlain by resistant sandstones like those in the Ferron Sandstone Member to about 2.6 acre- $\mathrm{ft} / \mathrm{mi}^{2}$ in areas underlain by shales like those in the Blue Gate Member.

\section{Benthic Invertebrates}

To determine baseline conditions before surface mining occurs, benthic invertebrates were sampled in Christiansen Wash and Quitchupah Creek at the eight locations shown in figure 16. Samples were taken in the summer and fall of 1978 and in the spring, summer, and fall of 1979. The samples were collected using a Surber sampler according to methods outlined by Greeson and others (1977, p. 171). Each sample represents those organisms collected from $3 \mathrm{ft}^{2}$ of stream bottom in riffle areas. Table 7 is a listing of organisms identified by phylogenetic order or family, the diversity index ${ }^{7}$ by order, and the total wet weight of organisms in each sample.

At the sites in Christiansen Wash, there were large seasonal and areal variations in the benthic-invertebrate population. However, 94 percent of all organisms collected were from the order Diptera (true flies), 4 percent from the order Trichoptera (caddis flies), with the remaining 2 percent composed of nine other orders. Of all organisms collected in Christiansen Wash, the families Chironomidae (midges) and Simuliidae (black flies) represented 89 percent. This dominance of the benthic-invertebrate population by two families indicates an environment that does not support a varied population of organisms.

As in Christiansen Wash, there were also large sea-

\footnotetext{
${ }^{7}$ According to Lium (1974, p. 382) "Diversity, or the evenness of distribution of insects, gives some indication of the environmental condition of a stream." Diversity was computed for each sample by order using the Shannon-Weıner approximatıon: Diversity index $=-\Sigma P I \log _{2} P I$

where $P I$ is the probability of occurrence of the $I^{\text {th }}$ order. The probability $(P I)$ is equal to $N I / N S$, where $N I$ is the number of individuals in each order and $N S$ is the total number of individuals in all orders
} 
sonal and areal variations in the benthic-invertebrate population in Quitchupah Creek. For all samples collected on Quitchupah Creek, the order Diptera (true flies) comprised 45 percent, Trichoptera (caddis flies) 30 percent, Ephemeroptera (mayflies) 13 percent, and Basommatophora (snails) 9 percent. The remaining 4 percent of the organisms were in an unknown order of aquatic worms and the orders Odonata (dragonflies), Hemiptera (true bugs), and Acarina (water mites).

The population of organisms in Quitchupah Creek was more diverse than the population in Christiansen Wash. However, the total number of organisms collected in Quitchupah Creek in 11 samples was 1,291 compared to 18,026 organisms collected in 13 samples from Christ-

EXPLANATION

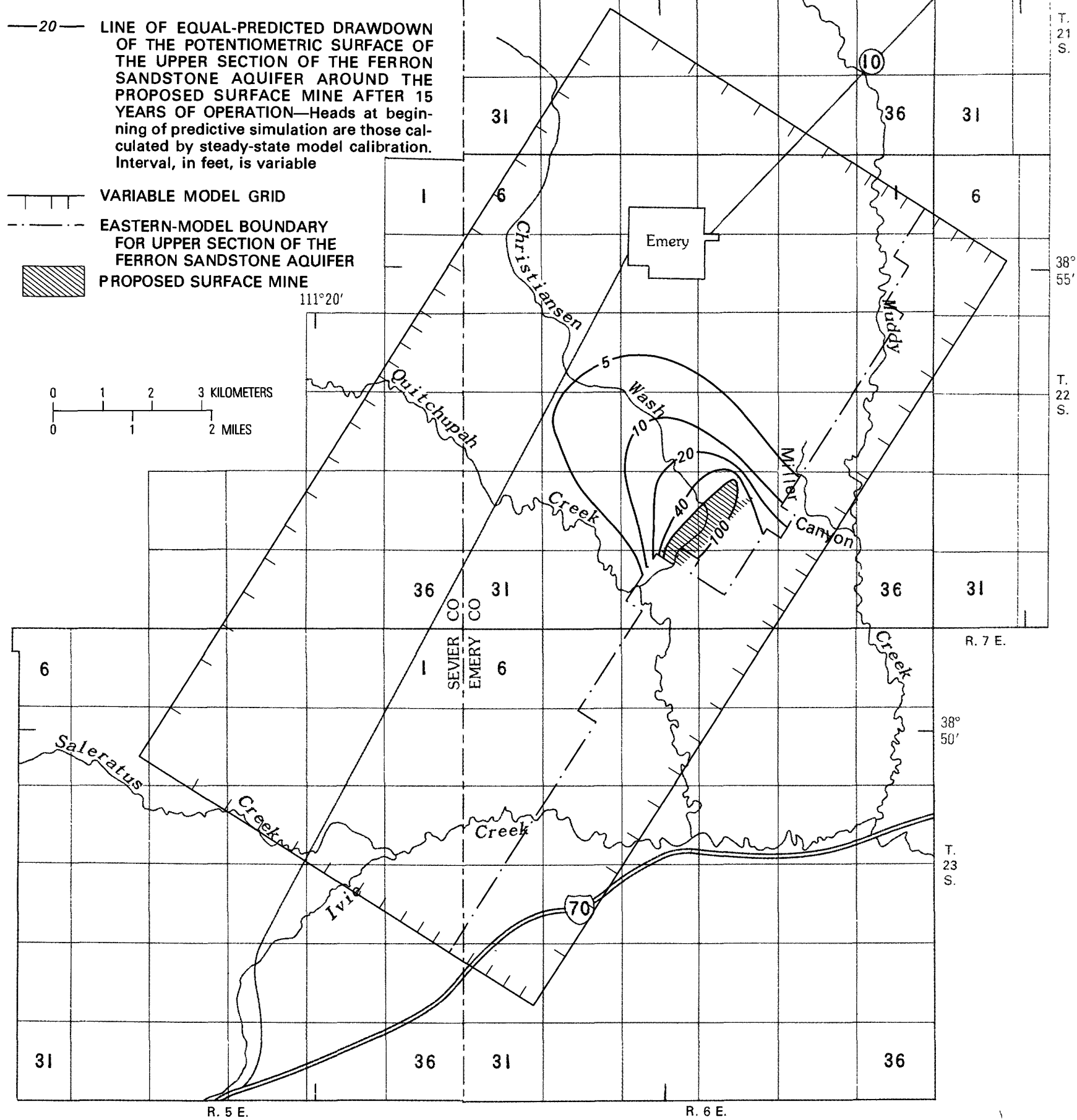

Figure 20. Variable grid used in the three-dimensional digital-computer model and the predicted drawdown of the potentiometric surface of the upper section of the Ferron sandstone aquifer around the proposed surface mine after 15 years of operation. 
iansen Wash. The reason for the differences in diversity of organisms may be that a more varied habitat (pools, riffles, and variety of substrate material) exists in Quitchupah Creek. However, the greater sediment loads and scouring from spring floods prevents large numbers of organisms from becoming established in Quitchupah Creek. Christiansen Wash has a less varied habitat, but more stable overall conditions allow certain groups of organisms to become well established.

Benthic invertebrates collected during 1978-79 indicate that there are large seasonal variations in diversity and numbers of individual organisms in Christiansen Wash and Quitchupah Creek. Additional samples are needed (particularly at the gaging station on Christiansen Wash downstream from the proposed surface mine) to further define the natural seasonal variability and to detect changes in the benthic-invertebrate population that may occur because of surface mining. Members of the orders Ephemeroptera, Plecoptera, and Trichoptera are especially susceptible to damage from increased sediment (R. H. Fuller, U.S. Geological Survey, written commun., 1980). Changes in $\mathrm{pH}$ and dissolved solids (including dissolved trace metals) associated with mining activities also have been shown to affect benthic invertebrates (Fuller and others, 1978, p. 22-27; Herricks and Cairns, 1973, p. 103).

\section{COMPUTER MODEL}

A three-dimensional digital-computer model was used to simulate ground-water flow in the Ferron sandstone aquifer in the Emery area. Approximately $60 \mathrm{mi}^{2}$ of the aquifer were modeled and the modeled area and grid used are shown in figure 20 . The model also was used to predict the effects of dewatering the proposed surface mine on potentiometric surfaces and the base flow of streams. The model used for this study is documented by Trescott (1975) and Trescott and Larson (1976). Changes were made to the original Trescott-Larson threedimensional model to allow simulation of leakage along streams from all layers of the model. The design, construction, and calibration of the model are discussed in detail by Morrissey, Lines, and Bartholoma (1980).

\section{Assumptions and Accuracy}

Predictions made with the model are considered to be semiquantitative for three reasons. The first reason is a lack of historical ground-water data in the modeled area, which results in an inability to verify the model with historical data for aquifer response to manmade discharge. The second reason is the assumption made in calibration of the model that the Ferron sandstone aquifer was in a steady-state condition during 1979. Although the aquifer was not in a true steady-state condition, the assumption of steady state is reasonable as water-level changes were only a few feet in most wells during 1979. The third reason involves an assumption inherent in the model that flow in the aquifer is through pore spaces. Although in some areas fractures are the major conduits through which water flows through the Ferron, the aquifer can be modeled because on a large scale the system probably acts as a porous medium.

Despite these limiting assumptions, the model provides the most realistic available method to analyze the effects of mine dewatering on the aquifer. The alternative approach, using an analytical method of analysis, would require more simplifying assumptions than those associated with the model. Thus, results of an analytical method could be used with less confidence than those obtained with the model.

\section{Prediction}

The calibrated model was used to predict the effects of dewatering the proposed surface mine on 1979 groundwater conditions. Transient and steady-state simulations of the proposed surface mine were made with the model. In simulating the surface mine, it was assumed that the pit would be dewatered, and this was simulated by constant-head nodes for layer 4 of the model (the upper section of the Ferron sandstone aquifer) in the mine area. The constant-head nodes were held at the altitude of the base of the coal seam to be mined. Grid spacing did not permit a precise simulation of the "moving" pit, and an average mine location was simulated. Constant-head nodes also were used to simulate the underground Emery Mine during the predictive simulations.

Aquifer tests of confined parts of the Ferron sandstone aquifer indicate that the storage coefficient ranges from about $3 \times 10^{-6}$ to $2 \times 10^{-3}$. During the transient-predictive simulation, a storage coefficient of $1 \times 10^{-4}$ was assigned to all layers of the Ferron where they were confined either by overlying shale or another layer of the Ferron. In areas where the aquifer was unconfined, a value of $5 \times 10^{-2}$ was assigned. Storage coefficients for layers 1 and 5 (the shales in the Tununk and Blue Gate Members) were not needed because these layers were simulated by constant-head nodes.

To check the sensitivity of the model to variations in storage coefficient, two additional simulations were made. In one simulation, the storage coefficients in confined areas were set at $1 \times 10^{-5}$ and in unconfined areas at $1 \times 10^{-2}$. In the second simulation, storage coefficients were set at $1 \times 10^{-3}$ in confined areas and at $1 \times 10^{-1}$ in unconfined areas. The results of these two simulations, as compared with results of the transient-predictive simulation, show that variations in storage do not seriously affect model predictions. Differences in calculated drawdowns at most nodes near the surface mine were less than 1 foot when using the different storage coefficients.

Results of predictive model simulations indicate that dewatering of the proposed surface mine will affect poten- 

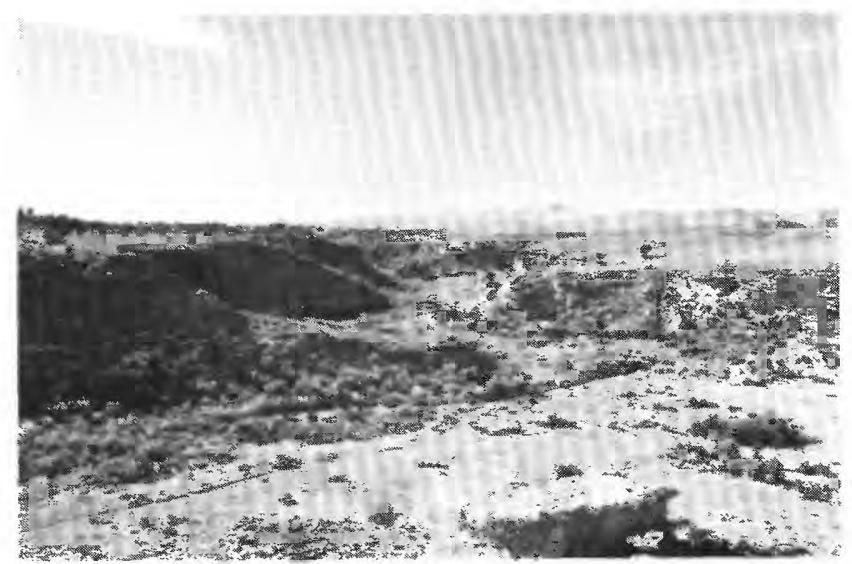

Figure 21. Area of proposed surface mine along Christiansen Wash. Ferron Sandstone Member of the Mancos Shale crops out along edges of flood plain; greasewood grows on alluvium along stream. View facing southwest.

tiometric surfaces of all layers of the Ferron sandstone aquifer, however, predicted drawdowns along model boundaries would be less than 4 feet. The predicted drawdowns in potentiometric surfaces and the effects on the base flow of streams are discussed in detail in following sections of this report.

\section{EFFECTS OF PROPOSED SURFACE MINING}

\section{Mining Plans}

In March 1976, application was filed with the Oil, Gas and Mining Division of the Utah Department of Natural Resources for a surface-coal mine in the Emery Coal Field. The proposed surface mine would be in the drainage of Christiansen Wash (fig. 20) near the existing underground Emery Mine. Approximately 430 acres would be directly disturbed by the mining operation. Coal would be mined from the I- and J-coal seams in the Ferron Sandstone Member. Surface mining would begin along Christiansen Wash in the area shown in figure 21 , where the coal is at the surface. The mining would proceed in strips to the northwest until an uneconomical depth was reached, about 120 feet according to the mining application. Mining would terminate on the Blue Gate Member in areas like that shown in figure 22 . The mine would have a life of about 15 years. There has been no surface mining the Emery Coal Field through 1980.

The proposed mining sequence is as follows: (1) construction of mine access roads and surface facilities, (2) removal and storage of surface material (soil), (3) drilling and blasting of overburden, (4) removal of overburden, (5) removal of coal, (6) grading of spoil overburden, (7) replacement of soil, and (8) revegetation.

Overburden from each successive mine cut would be placed in the previously mined cut or on adjacent land

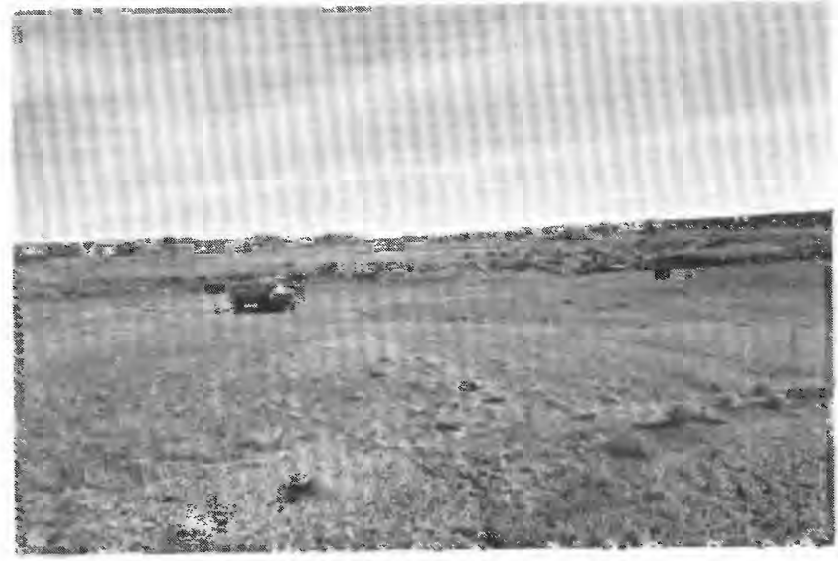

Figure 22. Sparsely vegetated surface of the Blue Gate Member of the Mancos Shale that is typical of area where proposed surface mining will terminate. Christiansen Wash and outcrop of the Ferron Sandstone Member of the Mancos Shale in background. View facing northeast.

not to be mined. Grading of the spoil overburden, replacement of soils, and revegetation would occur simultaneously with the mining operation. Maximum slope of land surface in the reclaimed mine area would be 18 percent and would occur along the final mine highwall.

According to the mining application, Christiansen Wash would be diverted around the northwest side of the mine. A diversion ditch also would be installed along the southeast side of the mine area to intercept and divert surface runoff from the Ferron outcrop into Christiansen Wash below the mine.

\section{Mine Dewatering}

\section{Effects on Ground Water}

The three-dimensional digital-computer model of the Ferron 'sandstone aquifer was used to evaluate the effects of dewatering the proposed surface mine on the aquifer. As pointed out earlier, predictions made with the model are considered to be semiquantitative.

Discharge from the surface mine is predicted to average about $0.3 \mathrm{ft}^{3} / \mathrm{s}$ during the proposed 15 years of operation. Model calculations indicate that water discharged from the surface mine would be balanced by a decrease in storage in the Ferron sandstone aquifer, by a decrease in water entering the underground Emery Mine, by a decrease in natural leakage from the aquifer, and by an increase in leakage to the aquifer from the Blue Gate Member.

The predicted drawdown in the potentiometric surface of the upper section of the Ferron sandstone aquifer (the section in which surface mining is proposed) after 15 years of mine dewatering is shown in figure 20 . It is predicted that drawdowns greater than 5 feet in the upper section of the aquifer would extend about 2.5 miles 
from the mine. Other sections of the Ferron sandstone aquifer also would be affected, but drawdowns would not be as great. In the basal section of the aquifer, it is predicted that drawdowns greater than 5 feet would extend about 2 miles from the proposed mine, and drawdowns greater than 10 feet would extend about 0.25 mile from the mine.

Model calculations indicate that dewatering of the surface mine would increase downward leakage into the Ferron sandstone aquifer from the Blue Gate Member by about $0.05 \mathrm{ft}^{3} / \mathrm{s}$; practically all ( 98 percent) of this increase would occur within the area of drawdown greater than 5 feet shown in figure 20. Water in the Blue Gate contained about $20,000 \mathrm{mg} / \mathrm{L}$ dissolved solids, and the dissolved-solids concentration of water in the upper section of the Ferron ranged from about 1,000 to $8,000 \mathrm{mg} / \mathrm{L}$ in the affected area during 1979. Thus, the additional downward leakage of water from the Blue Gate might cause deterioration of water quality in the upper section of the Ferron in some areas.

As discussed earlier, dewatering of the underground Emery Mine might have caused deterioration of water quality in the upper section of the Ferron sandstone aquifer in the area between the mine and the head of Miller Canyon. Dewatering of the surface mine might further deteriorate water quality in the upper section of the aquifer in the area between the surface mine and the canyon. However, as near the underground mine, water quality in the upper section of the aquifer might not deteriorate in other areas. The increased movement of less saline water through the aquifer toward the surface mine from the west might more than offset any deterioration that would be caused by increased leakage from the overlying Blue Gate Member west of the mine.

The predicted effects of dewatering of the surface mine on potentiometric surfaces and water quality in the Ferron are based upon conditions that existed in 1979. Ground-water conditions in the Ferron could be changed, however, by increased withdrawals from wells and from the underground Emery Mine. If ground-water conditions were significantly different during the surface mining, the effects of mining on the ground-water system would be different than those predicted.

\section{Effects on Surface Water}

Modeling results indicate that, except for Christiansen Wash, the dewatering of the proposed surface mine would not affect the base flow of streams. If water from the mine were discharged into Christiansen Wash, streamflow would increase accordingly. The predicted mine discharge $\left(0.3 \mathrm{ft}^{3} / \mathrm{s}\right)$ would be almost equal to the minimum observed discharge on Christiansen Wash during the 1979 water year.

Dissolved-solids concentrations in water in the upper section of the Ferron sandstone aquifer ranged from about
1,000 to $8,000 \mathrm{mg} / \mathrm{L}$ in the surface- mine area during 1979 , and water in the Blue Gate Member contained about $20,000 \mathrm{mg} / \mathrm{L}$ of dissolved solids. The water entering the surface mine would be a mixture of these two waters and water that would drain from the disturbed overburden. Chemical quality of the mine water would vary with time and would probably have a dissolved-solids concentration within a range of 2,000 to $10,000 \mathrm{mg} / \mathrm{L}$. The average dissolved-solids concentration of 12 monthly samples taken at the gaging station on Christiansen Wash below the mine area during the 1979 water year was $2,380 \mathrm{mg} / \mathrm{L}$, and the concentration ranged from 582 to $4,470 \mathrm{mg} / \mathrm{L}$. Thus, at least during some periods, the dissolved-solids concentration of water in Christiansen Wash would be increased if mine water were discharged into the stream.

\section{Leaching of Overburden}

\section{By Richard H. Fuller}

In the process of mining at the proposed 430-acre surface site, approximately 25,800 acre-feet $(41,600,000$ cubic yards) of overburden would be displaced, based on an average overburden thickness of 60 feet. The overburden would be highly fractured during the mining process; thus, it would be a readily available source of material that could be leached by surface water, ground water, and precipitation. In order to estimate the possible effects of leaching of overburden during the mining operation, laboratory leaching studies were carried out.

Cores of representative overburden were obtained from test holes. In the laboratory experiments, 100 grams of core material (table 3), which had been crushed to less than 0.25 inch in size, were placed in a 1-liter erlenmeyer flask with 750 milliliters of deionized water (similiar to rainfall and snowmelt) and shaken at room temperature. Samples were shaken from 12 to 26 weeks until the $\mathrm{pH}$ and specific conductance of the solution remained constant. Core material within the flasks had abraded to sand and clay sizes by the end of the equilibration period. These equilibration experiments showed the composition of leachate under oxidizing conditions (table 4). No attempt was made to simulate leaching under reducing conditions.

The results of the equilibration experiments (table 4) indicate water of better chemical quality than had been expected, especially when compared with many of the ground-water analyses reported in table 6 . The dissolved solids of the equilibrated samples ranged from 539 to $2,556 \mathrm{mg} / \mathrm{L}$, with a mean concentration of $1,160 \mathrm{mg} / \mathrm{L}$. The equilibrated samples were of the calcium sulfate water type, with the exception of samples $4 \mathrm{~A}-6,4 \mathrm{~A}-7$, and $5-11$, which were mixed calcium and magnesium sulfate waters, and sample 3-10, which was a sodium sulfate water. The major constituents found in the equilibration leachate are attributed to the alteration and solution of soluble salts such as mirabilite $\left(\mathrm{Na}_{2} \mathrm{SO}_{4} \cdot 10 \mathrm{H}_{2} \mathrm{O}\right)$, thenardite $\left(\mathrm{Na}_{2} \mathrm{SO}_{4}\right)$, and gypsum $\left(\mathrm{CaSO}_{4} \cdot 2 \mathrm{H}_{2} \mathrm{O}\right)$, which have 
Table 3. Description of samples from the Ferron Sandstone and Blue Gate Members of the Mancos Shale that were used in equilibration experiments

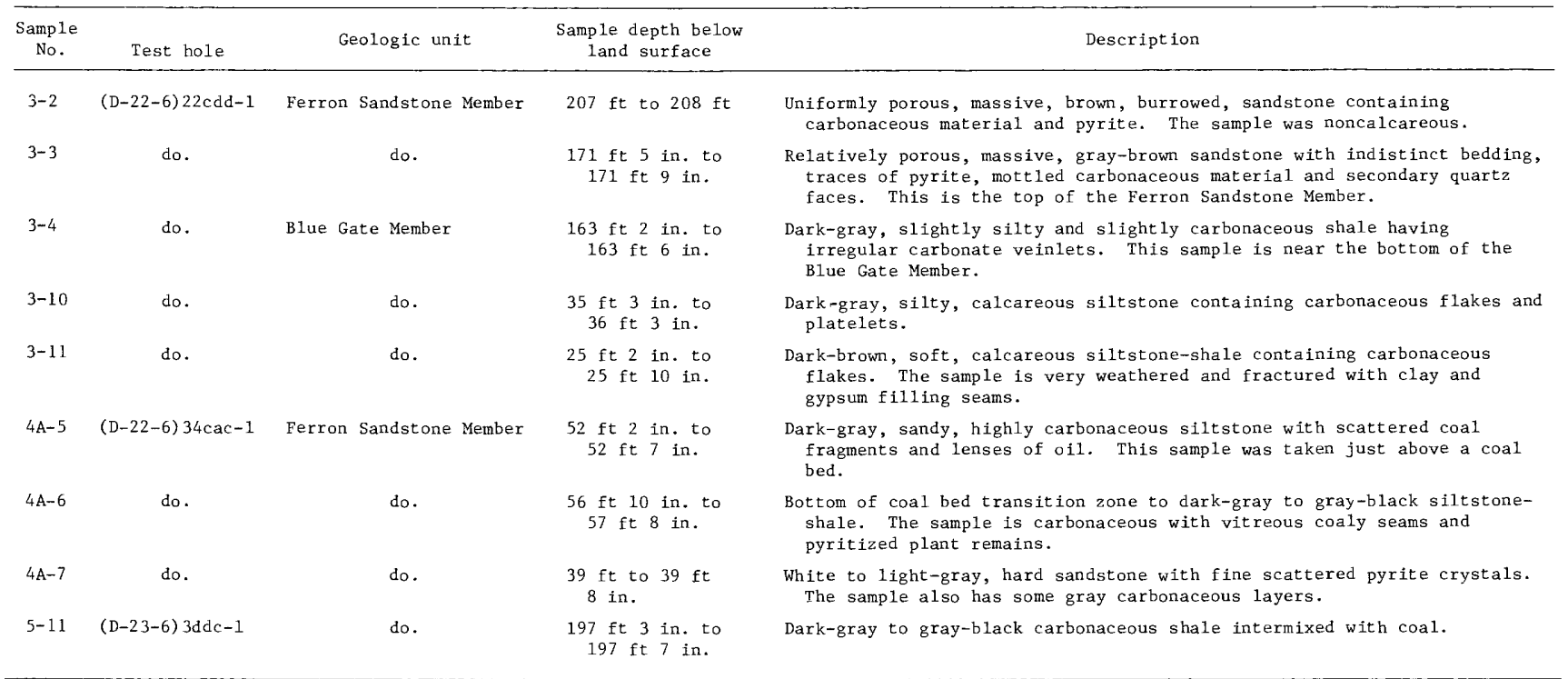

been reported to be in large quantities in the Mancos Shale (Waddell and others, 1979, p. 17). These minerals and pyrite and calcite all were common in the core samples. These minerals, with the exception of pyrite, are of a sodium or calcium sulfate composition; and this is reflected in the composition of the leachate. A detailed study of the chemical composition of the Ferron Sandstone Member and associated coal beds in the study area is given by Affolter, Hatch, and Ryer (1979).

The leachates contained relatively low concentrations of trace elements (table 4). Iron concentrations were unusually high in samples 3-2 and 4A-6, however, with concentrations of 61,000 and $7,000 \mu \mathrm{g} / \mathrm{L}$. This is attributed to the pyrite that was noted in both samples and was reflected in $\mathrm{pH}$ values of 4.0 and 3.8. Mixing pyritic material with calcareous material in mine-spoil placement would reduce iron mobilization and acid production. Aside from the two samples with large iron concentrations, trace elements in the leachates were found in quantities that would not be considered toxic to man, animals, or plants.

The concentration of dissolved solids in the leachates were considerably lower than in many of the ground-water samples taken during the course of the study. Three possible reasons for this are:

1. The short period of contact time (12 to 26 weeks) in the case of the equilibrated samples compared to years in the case of much of the ground water.

2. Some minerals, especially halite $(\mathrm{NaC} 1)$, are found in the Mancos Shale but were not present in appreciable quantities in the cores. Halite may account for much of the sodium and chloride found in some of the ground-water samples.

3. The equilibration experiments did not attempt to simulate reducing conditions or bacterial activity which undoubtedly have a significant influence on the solution of some minerals, especially pyrite and some of the sulfate minerals.

The equilibration studies indicate that the water in the mine spoil would be of a chemical quality that is better than much of the ground water in the mine area and about the same quality as water in Christiansen Wash. This would be the case if the water table were below the base of the spoil and if precipitation were the only water allowed to infiltrate the spoil. If surface or ground water is allowed to infiltrate the spoil, the resulting water quality would be worse than indicated by the equilibration studies because minerals dissolved from the spoil would add to the original concentrations in the infiltrating water.

\section{Erosion of Overburden}

Weather conditions during and after surface mining would influence both the success of land reclamation and the amount of sediment eroded from the disturbed area. It is not possible to predict the weather with sufficient precision to predict sediment yield from the proposed mine area. However, it is possible to identify those elements of mining and reclamation operations that are most likely to affect sediment yield and to identify environmental safeguards most likely to minimize the impact.

There are many environmental safeguards in regulations implementing Public Law 95-87, the Surface Mining Control and Reclamation Act of 1977 (U.S. Office of Surface Mining Reclamation and Enforcement, 1979). Many of the safeguards are designed to prevent additional contribution of sediment to streams outside the mine area. The regulations require that the smallest possible area at any one time be disturbed by mining operations and that 
Table 4. Chemical analyses of leachate after equilibration with typical spoil material from the Ferron Sandstone and Blue Gate Members of the Mancos Shale

Sample No.: Descriptions of samples are in table 3 .

Dissolved solids: Calculated from sum of constituents.

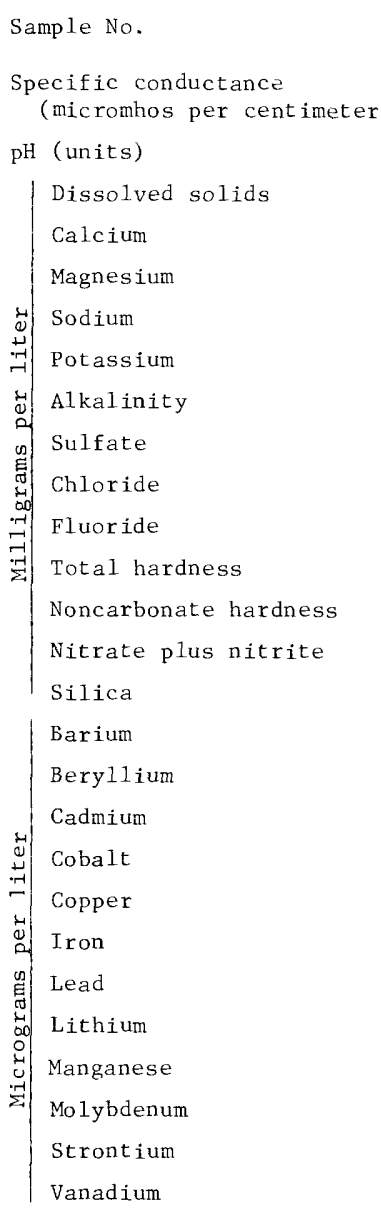

\begin{tabular}{|c|c|c|c|c|c|c|c|c|}
\hline \multicolumn{6}{|c|}{ Ferron Sandstone Member } & \multicolumn{3}{|c|}{ Blue Gate Member } \\
\hline $3-2$ & $3-3$ & $4 A-5$ & $4 A-6$ & $4 A-7$ & $5-11$ & $3-4$ & $3-10$ & $3-11$ \\
\hline 958 & 1,460 & 2,854 & 857 & 1,148 & 1,849 & 975 & 910 & 1,940 \\
\hline 4.0 & 6.9 & 7.4 & 3.8 & 7.5 & 8.0 & 7.5 & 7.6 & 7.3 \\
\hline 779 & 1,230 & 2,556 & 637 & 942 & 1,476 & 597 & 539 & 1,640 \\
\hline 65 & 300 & 428 & 45 & 117 & 120 & 120 & 37 & 380 \\
\hline 21 & 43 & 190 & 39 & 64 & 140 & 51 & 17 & 34 \\
\hline 18 & 8.6 & 25 & 46 & 36 & 54 & 18 & 130 & 31 \\
\hline 40 & 2.2 & 3.9 & 26 & 24 & 35 & 11 & 12 & 8.5 \\
\hline 0 & 110 & 98 & 0 & 570 & 3 & 200 & 330 & 110 \\
\hline 490 & 790 & 1,800 & 420 & 100 & 1,100 & 180 & 130 & 1,110 \\
\hline 3.3 & 4.5 & 3.1 & 3.4 & 5.9 & 5.8 & 2.5 & 3.3 & 2.9 \\
\hline 1.1 & .2 & .5 & .2 & .7 & .1 & .4 & .3 & .2 \\
\hline 250 & 930 & 1,900 & 280 & 560 & 880 & 510 & 160 & 1,100 \\
\hline 250 & 820 & 1,800 & 280 & 0 & 880 & 310 & 0 & 980 \\
\hline .63 & 0 & .06 & .44 & 1.0 & 3.4 & .16 & .02 & .01 \\
\hline 140 & 15 & 6.4 & 57 & 23 & 15 & 8.7 & 11 & 20 \\
\hline 50 & 10 & 20 & 20 & 30 & 30 & 50 & 30 & 30 \\
\hline 16 & 0 & 1 & 26 & $<1$ & 2 & 0 & 0 & 0 \\
\hline 4 & 5 & 2 & 5 & 3 & 6 & 1 & 0 & 1 \\
\hline 130 & 30 & 61 & 470 & $<3$ & 180 & 10 & $<5$ & 7 \\
\hline$<10$ & 30 & $<10$ & 56 & $<10$ & 10 & 30 & 10 & 10 \\
\hline 61,000 & 50 & 10 & 7,000 & 130 & 290 & 30 & 10 & 30 \\
\hline$<10$ & 30 & 34 & 34 & 16 & 57 & 30 & 30 & 30 \\
\hline 60 & 10 & 150 & 230 & 13 & 270 & 30 & 0 & 50 \\
\hline 1,200 & 1,000 & 800 & 300 & 89 & 600 & 100 & 30 & 300 \\
\hline$<10$ & 30 & 10 & 10 & 13 & 10 & 10 & 30 & 10 \\
\hline 590 & 1,000 & 5,700 & 2,800 & 430 & 2,400 & 5,000 & 500 & 1,000 \\
\hline 12 & $<10$ & $<10$ & 6 & 9 & 6 & $<10$ & $<10$ & $<10$ \\
\hline
\end{tabular}

there be progressive backfilling, grading, and prompt revegetation.

Probably the most important safeguard to minimize sediment loads downstream from the disturbed area is the use of sediment ponds. The ponds are required to be as near as possible downstream from the disturbed area, and they must be able to store the runoff resulting from the 10-year maximum 24-hour precipitation. Ponds must retain this flow for at least 10 hours. In the Emery area, the 10-year maximum 24-hour precipitation is about 1.7 inches (Miller and others, 1973, p. 37). The ponds also are required to store at a minimum the sediment that accumulates in 3 years from the drainage area, or a minimum of 0.035 acre-foot of sediment for each acre of disturbed area.

King and Mace (1953, table 6) found that basins in Castle Valley, which are sparsely vegetated and are underlain by shale and sandstone like those in the pro- posed surface-mine area, have annual sediment yields that normally range from 0.3 to 2.5 acre- $\mathrm{ft} / \mathrm{mi}^{2}$. Sediment loads of streams downstream from the mine area would not increase significantly if slopes were graded to the least possible angle, if revegetation were prompt so as to stabilize the stockpiled topsoil and backfilled overburden, and if runoff were channeled from the disturbed area through the sediment ponds. The long-term sediment yield from the disturbed area could actually decrease if vegetative cover were improved from premining conditions and sediment ponds were properly maintained.

Long-term sediment yields could also be minimized by permanently diverting Christiansen Wash and runoff from slopes southeast of the mine around the reclaimed area. Regulations for Public Law 95-87 require that natural riparian vegetation be enhanced or maintained along a permanent diversion and that the natural meandering shape and an acceptable gradient be established. Aquatic 
habitats, such as a pattern of riffles, pools, and drops, that approximate premining characteristics could also be established along the diversion of Christiansen Wash. However, until vegetation is established along diversions and until diversion channels have stabilized, erosion along the diversion channels would probably greatly increase sediment yield. Erosion along the freshly cut channels could be minimized by channel lining. Here again, impact on streams downstream from the mine area could be held to a minimum by channeling the diverted waters to properly constructed and maintained sediment ponds.

\section{NEED FOR FUTURE STUDY}

An observation-well network needs to be established in the Emery area for the semiannual measurement of water levels in three or four wells that tap each section of the Ferron sandstone aquifer and the overlying Blue Gate Member. The wells also need to be sampled annually to detect possible changes in water quality. Discharge from the Emery municipal well, the underground Emery Mine, and the surface mine (when operational) need to be monitored. After approximately 5 years, the additional data can be used to recalibrate and verify the three-dimensional digital-computer model of the aquifer.

\section{SUMMARY}

The largest quantities of water are available from the Ferron sandstone aquifer in the Emery area within about 2 miles of the Paradise Valley-Joes Valley fault system. Wells that fully penetrate the aquifer in this area could be expected to produce 100 to $500 \mathrm{gal} / \mathrm{min}$ if pumped. Elsewhere the availability of water from the Ferron is not as great, and in the northern two-thirds of Castle Valley the aquifer probably would not yield more than about $10 \mathrm{gal} / \mathrm{min}$ to individual wells. The chemical quality of water in the Ferron varies both with depth in the aquifer and areally. Fully penetrating wells near the fault system in the Emery area would yield water with concentrations of dissolved solids less than $1,000 \mathrm{mg} / \mathrm{L}$. In the northern part of Castle Valley, the concentration of dissolved solids in water from the Ferron probably would exceed 3,000 $\mathrm{mg} / \mathrm{L}$ and could exceed $20,000 \mathrm{mg} / \mathrm{L}$.

Simulations using the model of the Ferron sandstone aquifer in the Emery area indicate that dewatering of the proposed surface mine would average about $0.3 \mathrm{ft}^{3} / \mathrm{s}$ during the 15 years of operation. Dewatering of the mine would affect the potentiometric surfaces of all sections of the aquifer. The maximum drawdown would occur in the upper section of the aquifer, and drawdowns greater than 5 feet would extend about 2.5 miles from the mine. Downward leakage of poor quality water from the shale in the Blue Gate Member would be induced near the mine, and water quality in the upper section of the Ferron could deteriorate in some areas.
Except for Christiansen Wash, dewatering of the surface mine would not affect the base flow of streams. If water from the mine were discharged into Christiansen Wash, the streamflow would increase accordingly. Chemical analyses of ground water in the mine area and leaching experiments indicate that the chemical quality of water produced in the mine would vary. Concentrations of dissolved solids in the mine water should range from 2,000 to $10,000 \mathrm{mg} / \mathrm{L}$. If the mine water is discharged into Christiansen Wash, the dissolved solids in the stream water would be increased above premining concentrations, at least during some periods.

With proper reclamation practices and the use and maintenance of sediment ponds downstream from the mine area, there should be no significant increase in the sediment load of Christiansen Wash. Long-term sediment yield from the disturbed area could decrease if vegetative cover on reclaimed lands is improved from premining conditions and Christiansen Wash is permanently diverted around the mine area.

\section{REFERENCES CITED}

Affolter, R. H., Hatch, J. R., and Ryer, T. A., 1979, Chemical analyses of coal and shale from the Ferron Sandstone Member of the Mancos Shale, Emery coal field, Emery County, Utah: U.S. Geological Survey Open-File Report 79-858, $35 \mathrm{p}$.

Cotter, E. 1975a, Late Cretaceous sedimentation in a low-energy coastal zone: The Ferron Sandstone in Utah: Journal of Sedimentary Petrology, v. 45, p. 669-685.

1975b, Deltaic deposits in the upper Cretaceous Ferron Sandstone of Utah, in Broussard, M. L., ed., Deltas, models for exploration: Houston Geological Society, Houston, Texas, p. 471-484.

1976, The role of deltas in the evolution of the Ferron Sandstone and its coal: Brigham Young University Geology Stúdies, v. 22, part 3, p. 15-41.

Criddle, W. D., Harris, Karl, and Willardson, L. S., 1962, Consumptive use and water requirements for Utah: Utah State Engineer Technical Publication 8, 47 p.

Davis, L. J., 1954, Stratigraphy of the Ferron Sandstone: Intermountain Association of Petroleum Geologists, 5th Annual Field Conference Guidebook, p. 55-58.

Doelling, H. H., 1972, Central Utah coal fields: Utah Geological and Mineralogical Survey Monograph 3, $571 \mathrm{p}$.

Feltis, R. D., 1966, Water from bedrock in the Colorado Plateau of Utah: Utah State Engineer Technical Publication $15,82 \mathrm{p}$.

Fuller, R. H., Shay, J. M., Ferreira, R. F., and Hoffman, R. J., 1978, An evaluation of problems arising from acid mine drainage in the vicinity of Shasta Lake, Shasta County, California: U.S. Geological Survey Water-Resources Investigations $78-32,39 \mathrm{p}$.

Geoscientific Systems and Consulting, 1979, Reclaimability analysis of the Emery coal field, Emery County, Utah: U.S. 
Bureau of Land Management, Energy Minerals Rehabilitation Inventory and Analysis Report 16, 408 p.

Greeson, P. E., chm., and others, 1977. Methods for collection and analysis of aquatic biological and microbiological samples: U.S. Geological Survey Techniques of Water-Resources Investigations, book 5, chap. A4, $332 \mathrm{p}$.

Guy, H. P., chm., and others, 1977, National handbook of recommended methods for water-data acquisition, chapter 3 (sediment): U.S. Geological Survey Office of Water Data Coordination, $100 \mathrm{p}$.

Hale, L. A., 1972, Depositional history of the Ferron Formation, central Utah, in Plateau-Basin and Range transition zone, central Utah: Utah Geological Association Publication 2, p. $29-40$.

Hatch, J. R., Affolter, R. H., and Law, B. E., 1979, Chemical analyses of coal from the Emery and Ferron Sandstone Members of the Mancos Shale, Henry Mountains field, Wayne and Garfield Counties, Utah: U.S. Geological Survey Open-File Report 79-1097, 24 p.

Herricks, E. E., and Cairns, J., Jr., 1973, Rehabilitation of streams receiving acid mine drainage: Virginia Water Resources Center Bulletin 66, $284 \mathrm{p}$.

Hood, J. W. and Danielson, T. W., 1979, Bedrock aquifers in the lower Dirty Devil River basin area, Utah, with special emphasis on the Navajo Sandstone: U.S. Geological Survey Open-File Report 79-1163, 85 p.

Johnson, A. I., 1967, Specific yield-compilation of specific yields for various materials: U.S. Geological Survey WaterSupply Paper 1662-D, 74 p.

Katich, P. J., 1951, The stratigraphy and paleontology of the pre-Niobrara Upper Cretaceous rocks of Castle Valley, Utah: Unpublished PH.D. dissertation, Ohio State University, 208 p.

1953, Source direction of Ferron Sandstone in Utah: American Association of Petroleum Geologists Bulletin, v. 37, p. 858-862.

1954, Cretaceous and Early Tertiary stratigraphy of central and south-central Utah, with emphasis on the Wasatch Plateau area: Intermountain Association of Petroleum Geologists, 5th Annual Field Conference Guidebook, p. 43-54.

King, N. J., and Mace, M.M., 1953, Sedimentation in small reservoirs on the San Rafael Swell, Utah: U.S. Geological Survey Circular 256, $21 \mathrm{p}$.

Lium, B. W., 1974, Some aspects of aquatic insect populations of pools and riffles in gravel bed streams in Western United States: U.S. Geological Survey Journal of Research, v. 2, no. 3, p. 379-384.

Lohman, S. W., 1972, Ground-water hydraulics: U.S. Geological Survey Professional Paper 708, 70 p.

Lohman, S. W., and others, 1972, Definition of selected groundwater terms - revisions and conceptual refinements: U.S. Geological Survey Water-Supply Paper 1988, 21 p.

Lupton, C. T., 1916, Geology and coal resources of Castle Valley in Carbon, Emery, and Sevier Counties, Utah: U.S. Geological Survey Bulletin 628, 88 p.

Miller, J. R., Frederick, R. H., and Tracey, R. J., 1973, Precipitation frequency atlas of the Western United States-Utah: National Oceanic and Atmospheric Administration Atlas 2, v. 6,67 p.
Morrissey, D. J., Lines, G. C., and Bartholoma, S. D., 1980 , Three-dimensional digital-computer model of the Ferron sandstone aquifer near Emery, Utah: U.S. Geological Survey Water-Resources Investigations 80-62, p. 101.

Mundorff, J. C., 1972, Reconnaissance of chemical quality of surface water and fluvial sediment in the Price River basin, Utah: Utah Department of Natural Resources Technical Publication $39,55 \mathrm{p}$.

Mundorff, J. C., 1979, Reconnaissance of chemical quality of surface water and fluvial sediment in the Dirty Devil River basin, Utah: Utah Department of Natural Resources Technical Publication 65, $132 \mathrm{p}$.

Pettijohn, F. J., [1957], Sedimentary rocks (2d ed.): New York, Harper and Brothers, $718 \mathrm{p}$.

Stokes, W. L., ed., 1964, Geologic map of Utah: University of Utah, scale $1: 250,000$.

Sumsion, C. T., 1979, Selected coal-related ground-water data, Wasatch Plateau-Book Cliffs area, Utah: U.S. Geological Survey Open-File Report 79-915 (duplicated as Utah BasicData Report 32), 25 p.

Thatcher, L. L., Janzer, V. J., and Edwards, K. W., 1977, Methods for determination of radioactive substances in water and fluvial sediments: U.S. Geological Survey Techniques of Water-Resources Investigations, book 5, chap. A5, $95 \mathrm{p}$.

Trescott, P. C., 1975, Documentation of finite-difference model for simulation of three-dimensional ground-water flow: U.S. Geological Survey Open-File Report 75-438, 32 p.

Trescott, P. C., and Larson, S. P., 1976, Documentation of finite-difference model for simulation of three-dimensional ground-water flow, supplement to Open-File Report 75-438: U.S. Geological Survey Open-File Report 76-591, $21 \mathrm{p}$.

U.S. Geological Survey, 1980, Water Resources Data for Utah, water year 1979: Water-Data Report UT-79-1, 604 p.

U.S. Office of Surface Mining Reclamation and Enforcement, 1979, Surface coal mining and reclamation operations, permanent regulatory program: Federal Register, v. 44, no. 50, March 13, 1979, book 3, p. 15311-15463.

U.S. Weather Bureau, [1963], Normal annual and May-September precipitation (1931-60) for the State of Utah: Map of Utah, scale 1:500,000.

Waddell, K. M., Contratto, P. K., Sumsion, C. T., and Butler, J. R., 1979, Hydrologic reconnaissance of Wasatch PlateauBook Cliffs coal-fields area, Utah: U.S. Geological Survey Open-File Report 79-988, 85 p. (to be duplicated as WaterSupply Paper 2068).

Waddell, K. M., Vickers, H. L., Upton, R. T., and Contratto, P. K., 1978, Selected hydrologic data, 1931-77, Wasatch Plateau-Book Cliffs coal-fields area, Utah: U.S. Geological Survey Open-File Report 78-121 (duplicated as Utah BasicData Release 31), 33 p.

Williams, P. L., and Hackman, R. J., 1971, Geology, structure, and uranium deposits of the Salina Quadrangle, Utah: U.S. Geological Survey Miscellaneous Geologic Investigations Map I-591, scale 1:250,000, 2 sheets.

Witkind, I. J., 1979, Reconnaissance geologic map of the Wellington Quadrangle, Carbon County, Utah: U.S. Geological Survey Miscellaneous Investigations Map I-1178, scale $1: 24,000$. 
Table 5. Records of selected wells, test holes, and springs in the Castle Valley area

Location: See description of well- and spring-numbering system.

Owner, user, or name: BLM, U.S. Bureau of Land Management; Consol, Consolidation Coal Company; USGS, U.S. Geological Survey.

Casing: Depth--depth to top of perforations or first opening; $P$, depth to bottom of expandable packer.

Water-bearing zone(s): Age--Q, Quaternary; K, Cretaceous. Mappable unit--a, alluvium; p, pediment gravel; me, Emery Sandstone Member of Mancos Shale; mb, Blue Gate Member of Mancos Shale; mf, Ferron Sandstone Member of Mancos Shale; mt, Tununk Member of Mancos Shale.

Altitude of land-surface datum: Interpolated from topographic map.

Water level: Measured except as indicated by R, reported; F, flows at land surface; E, determined from electric log.

Discharge: Measured except as indicated by $R$, reported. Method of discharge--A, air line used to lift water to surface; F, natural flow;

$\mathrm{P}$, pumped.

Use of water, well, test hole, or spring: C, coal test; D, domestic; G, geophysical test; I, irrigation; M, municipal public supply; N, industrial; 0 , observation; $P$, petroleum or natural gas; $S$, stock watering; $T$, aquifer test; U, unused.

Remarks and other data available: A, aquifer-test data in files of J.S. Geological Survey, Salt Lake City, Utah; C, chemical analysis of water in table 4. Top of Ferron Sandstone Member in feet below land surface.

\begin{tabular}{|c|c|c|c|c|c|c|c|c|c|c|c|c|c|}
\hline \multirow{2}{*}{\multicolumn{2}{|c|}{ Location }} & \multirow[b]{2}{*}{ Owner, user, or name } & \multirow[b]{2}{*}{ 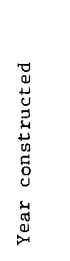 } & \multirow[b]{2}{*}{ 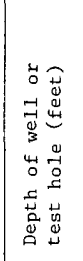 } & \multicolumn{2}{|c|}{ Casing } & \multirow{2}{*}{ 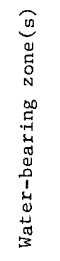 } & \multirow{2}{*}{ 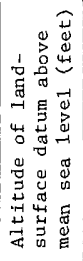 } & \multirow{2}{*}{ 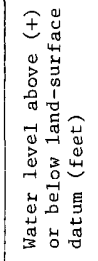 } & \multirow{2}{*}{ 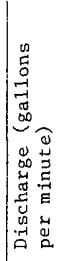 } & \multirow{2}{*}{ 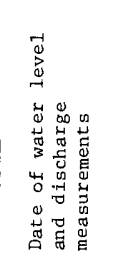 } & \multirow{2}{*}{ 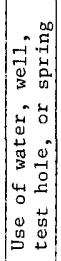 } & \multirow[b]{2}{*}{$\begin{array}{c}\text { Remarks and other data } \\
\text { available }\end{array}$} \\
\hline & & & & & 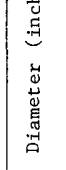 & 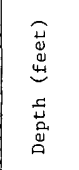 & & & & & & & \\
\hline \multirow[t]{2}{*}{$(D-13-7)$} & $15 \mathrm{cda}-1$ & $\begin{array}{l}\text { Stanolind Oil and } \\
\text { Gas Co. (No. 1) }\end{array}$ & 1954 & 6,502 & -- & -- & Kmf & 9,200 & -- & -- & -- & $\mathrm{P}$ & $\begin{array}{l}\text { Abandoned gas test. Top of } \\
\text { Ferron Sandstone Member at } \\
6,129 \mathrm{ft} \text {. C }\end{array}$ \\
\hline & $32 \mathrm{dbd}-1$ & $\begin{array}{l}\text { Mountain Fuel Supply } \\
\text { Co. (No. 3) }\end{array}$ & 1952 & 4,564 & -- & -- & $\mathrm{Kmf}$ & 8,450 & $\mathrm{~F}$ & $<1 \mathrm{~F}$ & $11-5-64$ & $\mathrm{P}$ & $\begin{array}{l}\text { Producing gas well. Top of } \\
\text { Ferron Sandstone Member at } \\
4,564 \mathrm{ft} \text {. C }\end{array}$ \\
\hline \multirow[t]{2}{*}{$(D-13-9)$} & $25 a d d-1$ & G. Haslam & 1971 & 210 & 4 & 120 & Kmb & 5,775 & 6.63 & -- & $9-18-75$ & $\mathrm{U}$ & $\mathrm{C}$ \\
\hline & $25 d c c-1$ & V. Sacco & 1956 & 31 & 6 & -- & $\mathrm{Qa}$ & 5,725 & 7.20 & -- & $9-18-75$ & D & C \\
\hline$(D-14-7)$ & $30 \mathrm{cad}-1$ & $\begin{array}{l}\text { Mountain Fue1 Supply } \\
\text { Co. (A-3) }\end{array}$ & 1963 & 4,049 & 5 & 3,797 & $\mathrm{Kmf}$ & 8,200 & -- & -- & -- & $\mathrm{P}$ & $\begin{array}{l}\text { Producing gas well. Top of } \\
\text { Ferron Sandstone Member at } \\
3,706 \mathrm{ft} \text {. C }\end{array}$ \\
\hline$(D-14-9) 2$ & $29 a b d-1$ & Amerada Petroleum Co. & 1962 & 4,215 & - & -- & $\mathrm{Kmf}$ & 6,320 & - & -- & -- & $\mathrm{P}$ & $\begin{array}{l}\text { Abandoned gas test. Ferron } \\
\text { Sandstone Member from 2,664 } \\
\text { to } 3,023 \mathrm{ft} \text {. Tununk Member } \\
\text { also produced water. C }\end{array}$ \\
\hline$(D-15-11)$ & $7 a a c-1$ & $\begin{array}{l}\text { Carbon Dioxide and } \\
\text { Chemical Co. }\end{array}$ & 1953 & 46 & 8 & 33 & $\mathrm{Qa}$ & 5,390 & 15.15 & -- & $9-27-79$ & $\mathrm{~N}$ & $\mathrm{C}$ \\
\hline$(D-17-7) 2$ & $25 d d c-1$ & Utah Southern oil Co. & 1954 & 4,577 & -- & -- & Kmf & 7,040 & $F$ & - & $3-\quad-54$ & $\mathrm{P}$ & $\begin{array}{l}\text { Abandoned gas test. Top of } \\
\text { Ferron Sandstone Member at } \\
3,577 \mathrm{ft} \text {. C }\end{array}$ \\
\hline$(D-17-9) 2$ & $23 a c b-1$ & A. Christiansen & 1979 & 200 & 4 & 120 & $\mathrm{Kmb}$ & 5,780 & 79.66 & -- & $9-27-79$ & $\mathrm{U}$ & $\mathrm{C}$ \\
\hline \multirow[t]{2}{*}{$(D-17-10)$} & $4 b b a-1$ & M. Coonrod & 1979 & 700 & -- & -- & -- & 5,660 & -- & -- & -- & U & $\begin{array}{l}\text { Driller reported no water en- } \\
\text { countered in Ferron Sand- } \\
\text { stone Member. }\end{array}$ \\
\hline & $16 \mathrm{dda}-1$ & L. Smith & 1979 & 205 & 4 & 185 & $\operatorname{Kmf}$ & 5,680 & 7.60 & -- & $10-30-79$ & $\mathrm{D}$ & $\mathrm{C}$ \\
\hline$(D-18-9)$ & $31 \mathrm{aba}-\mathrm{S} 1$ & BLM & $\rightarrow$ & -- & -- & -- & $\mathrm{Kmb}$ & 5,650 & - & $<\mathrm{IF}$ & - & $\mathrm{S}$ & $\mathrm{C}$ \\
\hline$(\mathrm{D}-20-7) 2$ & $27 \mathrm{cac}-1$ & $\begin{array}{l}\text { Eng1ish 0il Co. } \\
\quad \text { (No. 23-27) }\end{array}$ & 1962 & 983 & 4.5 & 804 & $\mathrm{Kmf}$ & 5,940 & -- & $-\infty$ & -- & $P$ & $\begin{array}{l}\text { Producing gas well. Ferron } \\
\text { Sandstone Member from } 790 \\
\text { to } 951 \mathrm{ft} \text {. C }\end{array}$ \\
\hline \multirow[t]{5}{*}{$(D-20-8)$} & $3 b b d-1$ & $\begin{array}{l}\text { Pacific Western } \\
\text { Exploration Co. }\end{array}$ & 1978 & 105 & -- & -- & $\operatorname{Kmf}$ & 5,600 & -- & -- & -- & G & Plugged. C \\
\hline & $4 \mathrm{dbc}-1$ & do. & 1978 & 120 & -- & -- & $\mathrm{Kmf}$ & & -- & -- & -- & G & Do. \\
\hline & $21 b d a-1$ & do. & 1978 & 100 & -- & -- & $\mathrm{Kmf}$ & 5,960 & 38.92 & -- & $5-18-78$ & G & Do. \\
\hline & $22 \mathrm{caa}-1$ & do. & 1978 & 100 & -- & -- & Kut & 5,870 & 29.67 & -- & $5-18-78$ & G & Plugged. \\
\hline & $29 \mathrm{bba}-1$ & do. & 1978 & 100 & -- & -- & Kmf & 5,850 & 10.73 & $-\infty$ & $5-18-78$ & $G$ & Plugged. C \\
\hline$(D-21-6)$ & $35 a a c-1$ & USGS & 1978 & 76 & 2 & 56 & $\mathrm{Kmb}$ & 6,260 & 53.10 & - & $5-10-78$ & 0 & $\begin{array}{l}\text { Converted geophysical test } \\
\text { hole. C }\end{array}$ \\
\hline$(D-21-7)$ & $4 a a c-1$ & do. & 1978 & 82 & 2 & 62 & $\mathrm{Kmb}$ & 6,250 & 44.34 & -- & $5-10-78$ & 0 & Do. \\
\hline$(D-22-4)$ & $17 \mathrm{cbd}-1$ & $\begin{array}{l}\text { Mountain Fuel Supply } \\
\text { Co. (No. 1) }\end{array}$ & 1955 & 6,471 & - & -- & $\mathrm{Kmf}$ & 8,155 & -- & -- & -- & $\mathrm{P}$ & $\begin{array}{l}\text { Abandoned gas test. Ferron } \\
\text { Sandstone Member from } 4,727 \\
\text { to } 5,340 \mathrm{ft} \text {. Several other } \\
\text { zones produced water, see } \\
\text { Feltis }(1966, \text { p. } 76) \text {. C }\end{array}$ \\
\hline \multirow[t]{2}{*}{$(D-22-5)$} & $23 a c a-1$ & K. D. Owen (No. 1) & 1953 & 3,670 & -- & -- & $\mathrm{Kmf}$ & 6,220 & $\mathrm{~F}$ & -- & $1-19-53$ & $P$ & $\begin{array}{l}\text { Abandoned gas test. Ferron } \\
\text { Sandstone Member from } 1,242 \\
\text { to } 1,775 \mathrm{ft} \text {. C }\end{array}$ \\
\hline & $34 \mathrm{dc}$ & Skelly oil Co. (No. 1) & 1962 & 10,740 & -- & -- & Knf & 6,350 & $\mathrm{~F}$ & $76 \mathrm{~F}$ & $2-8-62$ & $\mathrm{P}$ & $\begin{array}{l}\text { Ferron Sandstone Member from } \\
1,170 \text { to } 1,730 \mathrm{ft} . \mathrm{C}\end{array}$ \\
\hline \multirow[t]{3}{*}{$(D-22-6)$} & $4 c a b-1$ & City of Emery & 1966 & 1,614 & 5 & 1,586 & $\mathrm{Kmf}$ & 6,360 & +27.48 & $51 \mathrm{~F}$ & $6-14-78$ & M & $\begin{array}{l}\text { Open hole from } 1,586 \text { to } 1,614 \\
\text { ft. Top of Ferron Sandstone } \\
\text { Member at } 1,255 \mathrm{ft} \text {; entire } \\
\text { thickness not penetrated. } \\
\text { A. C }\end{array}$ \\
\hline & $4 c a b-2$ & do. & 1979 & 2,535 & 10 & 1,250 & $\mathrm{Kmf}$ & 6,360 & 98.25 & $100 \mathrm{P}$ & $10-27-79$ & M & $\begin{array}{l}\text { Open hole from } 1,555 \text { to } 1,900 \\
\text { ft; hole caved below. Ferro } \\
\text { Sandstone Member from } 1,250 \\
\text { to } 1,710 \mathrm{ft} \text {. Specific con- } \\
\text { ductance } 1,500 \text { micromhos } \\
\text { and water temperature } 25.0^{\circ} \mathrm{C} \\
\text { on } 10-25-79 \text {. }\end{array}$ \\
\hline & $17 a b c-1$ & Kemmerer Coal Co. & 1973 & 1,543 & 8 & 1,368 & $\mathrm{Kmf}$ & 6,285 & +45 & $176 \mathrm{~F}$ & $7-10-79$ & 0 & $\begin{array}{l}\text { Top of Ferron Sandstone Member } \\
\text { at } 1,053 \mathrm{ft} \text {; entire thick- } \\
\text { ness not penetrated. A. C }\end{array}$ \\
\hline
\end{tabular}


Table 5. Records of selected wells, test holes, and springs in the Castle Valley area-Continued

\begin{tabular}{|c|c|c|c|c|c|c|c|c|c|c|c|c|c|}
\hline \multirow{2}{*}{\multicolumn{2}{|c|}{ Location }} & \multirow[b]{2}{*}{ Owner, user, or name } & \multirow[b]{2}{*}{ 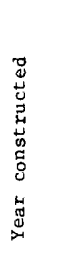 } & \multirow[b]{2}{*}{ 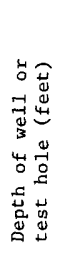 } & \multicolumn{2}{|c|}{ Casing } & \multirow{2}{*}{ 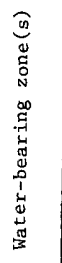 } & \multirow{2}{*}{ 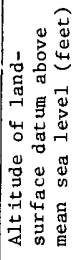 } & \multirow{2}{*}{ 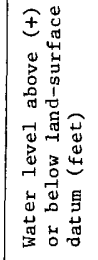 } & \multirow{2}{*}{ 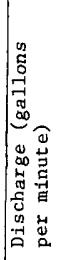 } & \multirow{2}{*}{ 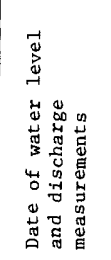 } & \multirow{2}{*}{ 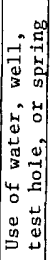 } & \multirow[b]{2}{*}{$\begin{array}{l}\text { Remarks and other data } \\
\text { available }\end{array}$} \\
\hline & & & & & 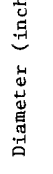 & 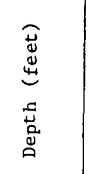 & & & & & & & \\
\hline \multirow[t]{33}{*}{$(D-22-6)$} & $17 a b c-2$ & USGS (No. 1-4) & 1978 & 1,100 & -- & $1,040 \mathrm{P}$ & $\mathrm{Kmf}$ & 6,280 & +26.80 & $2 \mathrm{~F}$ & $12-14-78$ & $\mathrm{~T}$ & $\begin{array}{l}\text { Plugged. Top of Ferron Sand- } \\
\text { stone Member at } 1,043 \mathrm{ft} \text {; } \\
\text { entire thickness not pene- } \\
\text { trated. Water table in } \\
\text { Blue Gate Member } 16 \mathrm{ft} \text { be- } \\
\text { low land surface on } \\
12-14-78 \text {. A. C }\end{array}$ \\
\hline & $19 \mathrm{cdb}-1$ & $\begin{array}{l}\text { G. Olson (Consol } \\
\text { FC 451) }\end{array}$ & 1979 & 410 & 4 & 390 & $\begin{array}{l}\mathrm{Kmb} \\
\mathrm{Kmf}\end{array}$ & 6,070 & +20 & $20 \mathrm{~F}$ & $5-16-79$ & I & Converted coal-test hole. C \\
\hline & $20 \mathrm{baa}-1$ & $\begin{array}{l}\text { Consol (Piezometer } \\
\text { site H) }\end{array}$ & 1979 & 1,140 & 1 & 1,113 & $\mathrm{Kmf}$ & 6,250 & +14 & $<1 \mathrm{~F}$ & $10-24-79$ & 0 & $\begin{array}{l}\text { Top of Ferron Sandstone Mem- } \\
\text { ber at } 815 \mathrm{ft} \text {; entire thick- } \\
\text { ness not penetrated. Cement } \\
\text { grout around casing from } \\
995 \text { to } 1,018 \mathrm{ft} \text {. C }\end{array}$ \\
\hline & $20 \mathrm{baa}-2$ & do. & 1979 & 995 & 1 & 969 & $\mathrm{Kmf}$ & 6,250 & +27 & $<1$ & $10-23-79$ & 0 & $\begin{array}{l}\text { Cement grout around casing } \\
\text { from } 869 \text { to } 880 \mathrm{ft} \text {. C }\end{array}$ \\
\hline & $20 \mathrm{baa}-3$ & do. & 1979 & 869 & 1 & 840 & $\mathrm{Kmf}$ & 6,250 & 62.18 & -- & $11-15-79$ & 0 & $\begin{array}{l}\text { Cement grout around casing } \\
\text { from } 808 \text { to } 835 \mathrm{ft} \text {. }\end{array}$ \\
\hline & $20 \mathrm{baa}-4$ & do. & 1979 & 808 & 1 & 40 & $\mathrm{Kmb}$ & 6,250 & 32.14 & -- & $10-24-79$ & 0 & $\begin{array}{l}\text { Cement grout around casing } \\
\text { from surface to } 17 \mathrm{ft} .\end{array}$ \\
\hline & $21 c c b-1$ & USGS (No. 1-3) & 1978 & 725 & -- & $600 \mathrm{P}$ & $\mathrm{Kmf}$ & 6,155 & 107.22 & $3 A$ & $12-1-78$ & $\mathrm{~T}$ & $\begin{array}{l}\text { Plugged. Top of Ferron Sand- } \\
\text { stone Member at } 598 \mathrm{ft} \text {; en- } \\
\text { tire thickness not pene- } \\
\text { trated. Water table in Blue } \\
\text { Gate Member } 24 \mathrm{ft} \text { below land } \\
\text { surface on } 12-1-78 \text {. C }\end{array}$ \\
\hline & $21 \mathrm{cdd}-1$ & $\begin{array}{l}\text { Consol (Piezometer } \\
\text { site I) }\end{array}$ & 1979 & 728 & 1 & 695 & $\mathrm{Kmf}$ & 6,110 & 11.33 & -- & $10-25-79$ & 0 & $\begin{array}{l}\text { Top of Ferron Sandstone Member } \\
\text { at } 415 \mathrm{ft} \text {; entire thickness } \\
\text { not penetrated. Cement grout } \\
\text { around casing from } 609 \text { to } \\
636 \mathrm{ft} \text {. }\end{array}$ \\
\hline & $2 l c d d-2$ & do. & 1979 & 609 & 1 & 587 & $\mathrm{Kmf}$ & 6,110 & 62.25 & -- & $10-25-79$ & 0 & $\begin{array}{l}\text { Cement grout around casing } \\
\text { from } 475 \text { to } 508 \mathrm{ft} .\end{array}$ \\
\hline & $21 c d d-3$ & do. & 1979 & 475 & 1 & 441 & $\mathrm{Kmf}$ & 6,110 & 335.70 & -- & $11-15-79$ & 0 & $\begin{array}{l}\text { Cement grout around casing } \\
\text { from } 405 \text { to } 425 \mathrm{ft} \text {. Piezo- } \\
\text { meter probably plugged and } \\
\text { not open to aquifer. }\end{array}$ \\
\hline & $21 c d d-4$ & do. & 1979 & 344 & 1 & 63 & $\mathrm{Kmb}$ & 6,110 & 9.56 & -- & $10-25-79$ & 0 & \\
\hline & $22 c d d-1$ & USGS（EMRIA 3） & 1978 & 275 & 4 & 100 & $\mathrm{Kmf}$ & 6,100 & 58.90 & IOP & $4-19-79$ & $\mathrm{~T}, 0$ & $\begin{array}{l}\text { Top of Ferron Sandstone Mem- } \\
\text { ber ar } 171 \mathrm{ft} \text {; entire } \\
\text { thickness not penetrated. } \\
\text { Cement grout around casing } \\
\text { from surface to } 90 \mathrm{ft} \text {. A. C }\end{array}$ \\
\hline & $22 c d d-2$ & USGS (EMRIA 3A) & 1978 & 270 & 2 & 230 & $\mathrm{Kmf}$ & 6,090 & 44.05 & -- & $9-22-78$ & $\mathrm{~T}, 0$ & $\begin{array}{l}\text { Cement grout around casing } \\
\text { from surface to } 200 \mathrm{ft} \text {. }\end{array}$ \\
\hline & $22 \mathrm{cdd}-3$ & USGS（EMRIA 3B) & 1978 & 40 & 6 & 20 & $\mathrm{Kmb}$ & 6,090 & 16.55 & -- & $9-22-78$ & $\mathrm{~T}, 0$ & \\
\hline & $23 a a c-1$ & USGS (EMRIA 1A) & 1978 & 315 & 2 & 275 & $\mathrm{Kmf}$ & 6,190 & 149.14 & -- & $10-27-78$ & $\mathrm{~T}, 0$ & \\
\hline & $23 \mathrm{adb}-1$ & USGS (EMRIA 1) & 1978 & 305 & 4 & 20 & $\mathrm{Kmf}$ & 6,180 & 138.17 & $2 \mathrm{P}$ & $10-25-78$ & $\mathrm{~T}, 0$ & Converted coal-test hole. C \\
\hline & $23 \mathrm{bcc}-1$ & Consol (FC 346) & 1974 & 355 & 3 & 149 & $\mathrm{Kmf}$ & 6,120 & 24.49 & -- & $10-7-76$ & 0 & Converted coal-test hole. \\
\hline & $23 c c a-1$ & $\begin{array}{l}\text { Pacific Western } \\
\text { Exploration Co. }\end{array}$ & 1978 & 100 & -- & -- & $\mathrm{Kmf}$ & 6,100 & 32.23 & -- & $5-31-78$ & G & Plugged. C \\
\hline & $23 \mathrm{cdc}-\mathrm{S} 1$ & M. Christiansen & -- & -- & -- & -- & $\mathrm{Kmf}$ & 6,050 & -- & $6 \mathrm{~F}$ & $10-24-79$ & $\mathrm{U}$ & $\begin{array}{l}\text { Specific conductance } 4,500 \\
\text { micromhos and water temper- } \\
\text { ature } 9.5^{\circ} \mathrm{C} \text { on } 10-24-79 .\end{array}$ \\
\hline & $23 \mathrm{dda}-\mathrm{S} 1$ & BLM & - & -- & $-\infty$ & -- & Kmf & 5,900 & -- & $5 \mathrm{~F}$ & $4-4-79$ & $\mathrm{U}$ & $\mathrm{C}$ \\
\hline & $26 \mathrm{bac}-1$ & $\begin{array}{l}\text { Pacific Western } \\
\text { Exploration Co. }\end{array}$ & 1978 & 100 & -- & -- & $\mathrm{Kmf}$ & 6,010 & 7.71 & - & $5-31-78$ & G & Plugged. C \\
\hline & $26 \mathrm{bba}-1$ & do. & 1978 & 100 & -- & -- & $\mathrm{Kmf}$ & 6,040 & 28.95 & -- & $5-31-78$ & G & Do. \\
\hline & $26 b b b-1$ & USGS（EMRIA 2) & 1978 & 349 & 4 & 40 & $\mathrm{Kmf}$ & 6,080 & 26.52 & $9 \mathrm{P}$ & $6-19-79$ & $\mathrm{~T}, 0$ & Converted coal-test hole. A. C \\
\hline & $26 \mathrm{bbb}-2$ & USGS (EMRIA 2A) & 1978 & 300 & 2 & 30 & $\mathrm{Kmf}$ & 6,080 & 33.50 & -- & $10-27-78$ & $\mathrm{~T}, 0$ & \\
\hline & $26 \mathrm{bdb}-1$ & $\begin{array}{l}\text { Pacific Western } \\
\text { Exploration Co. }\end{array}$ & 1978 & 100 & -- & -- & $\mathrm{Kmf}$ & 6,000 & 7.89 & -- & $5-31-78$ & G & Plugged. C \\
\hline & $26 \mathrm{dcb}-1$ & do. & 1978 & 100 & -- & -- & Kmt & 5,970 & 11.98 & -- & $5-31-78$ & G & Do. \\
\hline & $27 \mathrm{bda}-1$ & USGS (Muddy No. 4) & 1979 & 113 & 2.5 & 93 & $\mathrm{Kmf}$ & 6,060 & 8.19 & -- & $6-13-79$ & 0 & Converted coal-test hole. \\
\hline & $27 \mathrm{cbb}-1$ & Consol (FC 363) & 1975 & 400 & 3 & 22 & $\begin{array}{l}\mathrm{Kmb}, \\
\mathrm{Kmf}\end{array}$ & 6,050 & 7.69 & -- & $10-7-76$ & 0 & Do. \\
\hline & $27 \mathrm{cbb}-2$ & USGS (No. 1-1) & 1978 & 380 & 2 & 310 & $\mathrm{Kmf}$ & 6,060 & 42.65 & $3 \mathrm{~A}$ & $11-17-78$ & $\mathrm{~T}, 0$ & $\begin{array}{l}\text { Top of Ferron Sandstone Mem- } \\
\text { ber at } 73 \mathrm{ft} \text {; entire thick- } \\
\text { ness not penetrated. Cement } \\
\text { grout around casing from } \\
\text { surface to } 310 \mathrm{ft} \text {. A. C }\end{array}$ \\
\hline & $27 \mathrm{cbb}-3$ & USGS (No. 1-2) & 1978 & 150 & 2 & 75 & $\mathrm{Kmf}$ & 6,060 & 37.68 & -- & $12-10-78$ & $\mathrm{~T}, 0$ & $\begin{array}{l}\text { Cement grout around casing } \\
\text { from surface to } 75 \mathrm{ft} \text {; open } \\
\text { hole below. C }\end{array}$ \\
\hline & $27 \mathrm{cbb}-4$ & USGS (No. 3-1) & 1979 & 71 & 2 & 51 & $\mathrm{Kmb}$ & 6,060 & 17.23 & -- & $6-13-79$ & 0 & $\mathrm{C}$ \\
\hline & $27 \mathrm{cbb}-5$ & USGS (Muddy No. 3) & 1979 & 158 & 4 & 118 & $\begin{array}{l}\mathrm{Kmb} \\
\mathrm{Kmf}\end{array}$ & 6,065 & 42.26 & $3 \mathrm{P}$ & $8-22-79$ & $\mathrm{~T}, 0$ & Converted coal-test hole. A. C \\
\hline & $27 \mathrm{cbb}-6$ & USGS (No. 4-1) & 1979 & 30 & 2.5 & 10 & $\mathrm{Kmb}$ & 6,060 & 18.77 & -- & $6-13-79$ & 0 & \\
\hline
\end{tabular}


Table 5. Records of selected wells, test holes, and springs in the Castle Valley area-Continued

\begin{tabular}{|c|c|c|c|c|c|c|c|c|c|c|c|c|c|}
\hline \multirow{2}{*}{\multicolumn{2}{|c|}{ Location }} & \multirow[b]{2}{*}{ Owner, user, or name } & \multirow[b]{2}{*}{ 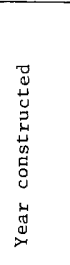 } & \multirow[b]{2}{*}{ 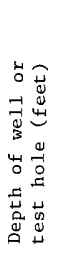 } & \multicolumn{2}{|c|}{ Casing } & \multirow[b]{2}{*}{ 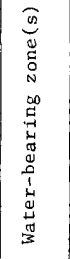 } & \multirow[b]{2}{*}{ 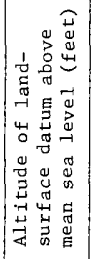 } & \multirow[b]{2}{*}{ 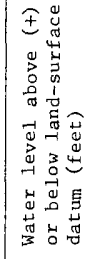 } & \multirow[b]{2}{*}{ 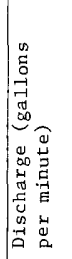 } & \multirow[b]{2}{*}{ 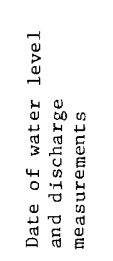 } & \multirow[b]{2}{*}{ 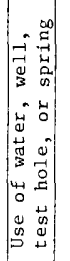 } & \multirow[b]{2}{*}{$\begin{array}{l}\text { Remarks and other data } \\
\text { available }\end{array}$} \\
\hline & & & & & 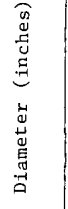 & 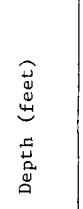 & & & & & & & \\
\hline \multirow{19}{*}{$(D-22-6)$} & $28 \mathrm{bcc}-\mathrm{S} 1$ & $\begin{array}{l}\text { Cedar Ridge Land and } \\
\text { Livestock Co. }\end{array}$ & -- & - & -- & -- & Qp & 6,080 & -- & $1 \mathrm{~F}$ & $9-25-79$ & $\mathrm{U}$ & C \\
\hline & $28 \mathrm{dab}-1$ & Conso 1 . & 1976 & 236 & 3 & 156 & $\begin{array}{l}\text { Kmb, } \\
\text { Kmf }\end{array}$ & 6,075 & 23.29 & -- & $9-16-76$ & 0 & \multirow[t]{2}{*}{$\begin{array}{l}\text { Top of Ferron Sandstone Mem- } \\
\text { ber at } 156 \mathrm{ft} \text {; entire thick- } \\
\text { ness not penetrated. }\end{array}$} \\
\hline & $28 \mathrm{dab}-2$ & do. (FC 343) & 1974 & 256 & 3 & 148 & $\begin{array}{l}\text { Kmb, } \\
\text { Kmf }\end{array}$ & 6,085 & 23.53 & -- & $10-7-76$ & 0 & \\
\hline & $\begin{array}{l}28 \mathrm{ddb}-1 \\
29 \mathrm{bba}-\mathrm{Sl}\end{array}$ & $\begin{array}{l}\text { USGS (Muddy No. 2) } \\
\text { A. Jensen }\end{array}$ & 1979 & 136 & 2.5 & 96 & Kmf & $\begin{array}{l}6,045 \\
6,140\end{array}$ & 44.18 & $\overline{6 \mathrm{~F}}$ & $\begin{array}{r}6-13-79 \\
11-15-79\end{array}$ & $\begin{array}{l}0 \\
U\end{array}$ & \multirow{3}{*}{$\begin{array}{l}\text { Converted coal-test hole. } \\
\mathrm{C} \\
\text { Top of Ferron Sandstone Mem- } \\
\text { ber at } 581 \mathrm{ft} \text {; entire } \\
\text { thickness not penetrated. } \\
\text { Cement grout around casing } \\
\text { from surface to } 830 \mathrm{ft} \text {. C } \\
\text { Cement grout around casing } \\
\text { from } 652 \text { to } 682 \mathrm{ft} \text {. Shut-in } \\
\text { water pressure could not be } \\
\text { determined because of gas. }\end{array}$} \\
\hline & $30 \mathrm{aad}-1$ & $\begin{array}{l}\text { Consol (Piezometer } \\
\text { site R) }\end{array}$ & 1979 & 884 & 1 & 838 & $\mathrm{Qp}$ & $6,140+$ & $+83^{--}$ & $\begin{array}{l}\mathrm{OF} \\
--\end{array}$ & $12-4-79$ & ( & \\
\hline & $30 \mathrm{aad}-2$ & do. & 1979 & 825 & 1 & 798 & $\mathrm{Kmf}_{\mathrm{mf}}$ & 6,030 & $\mathrm{~F}$ & -- & $12-4-79$ & 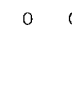 & \\
\hline & $30 \mathrm{aad}-3$ & do. & 1979 & 652 & 1 & 599 & $\mathrm{Kmf}$ & 6,030 & +.42 & -- & $12-4-79$ & 0 & $\begin{array}{l}\text { Cement grout around casing } \\
\text { from } 554 \text { to } 581 \mathrm{ft} .\end{array}$ \\
\hline & $30 \mathrm{aad}-4$ & do. & 1979 & 554 & 1 & 105 & $\mathrm{Kmb}$ & 6,030 & 53.39 & -- & $12-4-79$ & 0 & $\begin{array}{l}\text { Cement grout around casing } \\
\text { from surface to } 11 \mathrm{ft} .\end{array}$ \\
\hline & $30 \mathrm{bdd}-1$ & USGS & 1978 & 40 & 2 & 20 & $\mathrm{Kmb}$ & 6,020 & 8.37 & -- & $11-7-78$ & 0 & $\begin{array}{l}\text { Converted geophysical test } \\
\text { hole. }\end{array}$ \\
\hline & $30 \mathrm{dcb}-1$ & J. Lewis & 1979 & 608 & 4 & 590 & $\begin{array}{l}\mathrm{Kmb}, \\
\mathrm{Kmf}\end{array}$ & 6,030 & +8.50 & $27 \mathrm{~F}$ & $10-18-79$ & $\mathrm{I}, \mathrm{S}$ & $\begin{array}{l}\text { Top of Ferron Sandstone Mem- } \\
\text { ber at about } 600 \mathrm{ft} \text {; entire } \\
\text { thickness not penetrated. } \\
\text { Cement grout around casing } \\
\text { from about } 540 \text { to } 590 \mathrm{ft} .{ }^{\mathrm{C}} \mathrm{C}\end{array}$ \\
\hline & $31 \mathrm{dab}-1$ & E. Bryant & 1972 & 406 & 6 & 360 & $\mathrm{Kmf}$ & $6,020+$ & +10.41 & $45 \mathrm{~F}$ & $7-6-78$ & $\mathrm{I}, \mathrm{S}$ & $\begin{array}{l}\text { Top of Ferron Sandstone Mem- } \\
\text { ber at } 365 \mathrm{ft} \text {; entire } \\
\text { thickness not penetrated. } \\
\text { A. C }\end{array}$ \\
\hline & $32 c d c-1$ & $\begin{array}{l}\text { Consol (Piezometer } \\
\text { site } \mathrm{AA} \text { ) }\end{array}$ & 1979 & 490 & 1 & 420 & $\mathrm{Kmf}$ & 5,980 & 73.03 & -- & $11-16-79$ & 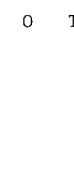 & $\begin{array}{l}\text { Top of Ferron Sandstone Mem- } \\
\text { ber at } 95 \mathrm{ft} \text {; entire thick- } \\
\text { ness not penetrated. Cement } \\
\text { grout around casing from } \\
396 \text { to } 418 \mathrm{ft} \text {. Piezoneter } \\
\text { probably plugged and not } \\
\text { open to aquifer. }\end{array}$ \\
\hline & $32 c d c-2$ & do. & 1979 & 396 & 1 & 336 & $\mathrm{Kmf}$ & 5,980 & +1.74 & -- & $11-16-79$ & 0 & $\begin{array}{l}\text { Jement grout around casing } \\
\text { from } 215 \text { to } 232 \mathrm{ft} \text {. }\end{array}$ \\
\hline & $32 \mathrm{cdc}-3$ & do. & 1979 & 21.2 & 1 & 168 & $\mathrm{Kmf}$ & 5,980 & $\mathrm{~F}$ & -- & $11-16-79$ & c & $\begin{array}{l}\text { Cement grout around casing } \\
\text { from } 79 \text { to } 96 \mathrm{ft} \text {. Shut-in } \\
\text { water pressure could not be } \\
\text { determined because of gas. }\end{array}$ \\
\hline & $32 c d c-4$ & do. & 1979 & 79 & 1 & 61 & $\mathrm{Kmb}$ & 5,980 & 24.84 & -- & $11-16-79$ & 0 & $\begin{array}{l}\text { Cement grout around casing } \\
\text { from surface to } 17 \mathrm{ft} \text {. }\end{array}$ \\
\hline & $33 a b b-1$ & USGS (Muddy No. 1) & 1979 & 162 & 2.5 & 122 & $\mathrm{KmE}$ & 6,0401 & 141.08 & -- & $7-2-79$ & 0 & Converted coal-test hole. \\
\hline & $33 a b b-2$ & Consol (Site $\mathrm{ZZ}$ ) & 1979 & 390 & 4 & 310 & $\mathrm{Kmf}$ & 6,0401 & 145.16 & -- & $9-28--79$ & 0 & $\begin{array}{l}\text { Cement grout around casing } \\
\text { from surface to } 96 \mathrm{ft} \text {. C }\end{array}$ \\
\hline & $34 \mathrm{bba}-1$ & USGS (No. 2-4) & 1978 & $\begin{array}{l}160 \\
360\end{array}$ & -- & -- & $\begin{array}{l}\mathrm{Kmf} \\
\mathrm{Kmf}\end{array}$ & 6,110 & $\begin{array}{r}86.29 \\
107.00\end{array}$ & $\begin{array}{r}3 \mathrm{~A} \\
1 \mathrm{~A}\end{array}$ & $\begin{array}{l}12-1.2-78 \\
12-14-78\end{array}$ & $\mathrm{~T}$ & $\begin{array}{l}\text { Plugged. } \mathrm{C} \\
\mathrm{C}\end{array}$ \\
\hline & $34 \mathrm{cac}-1$ & BLM (EMRIA 4A) & 1977 & 200 & -- & - & $\mathrm{Kmf}$ & 6,200 & 10 - & -- & -- & $\mathrm{C}$ & $\begin{array}{l}\text { plugged. Driller reported } \\
\text { hole was dry. }\end{array}$ \\
\hline$(D-22-7)$ & $8 \mathrm{bcd}-1$ & $\begin{array}{l}\text { Cedar Ridge Land and } \\
\text { Livestock Co. }\end{array}$ & -- & 130 & -- & -- & $\mathrm{Kmf}$ & 6,260 & 77 & - & $10-26-78$ & $\mathrm{D}$ & C \\
\hline$(\mathrm{D}-23-5)$ & $2 \mathrm{ddc}-1$ & Emery Energy & 1979 & 926 & -- & -- & $\mathrm{Kmf}$ & 6,340 & $149 \mathrm{E}$ & -- & $4-18-79$ & $\mathrm{C}$ & Plugged. \\
\hline & $12 \mathrm{bcd}-1$ & BLM (Consol No. 487) & 1979 & 709 & 6 & 28 & $\mathrm{Kmf}$ & 6,140 & $\mathrm{~F}$ & $3 \mathrm{~F}$ & $12-28-79$ & S & $\begin{array}{l}\text { Specific conductance } 950 \\
\text { micromhos and water temper- } \\
\text { ature } 17.0^{\circ} \mathrm{C} \text { on } 12-28-79 .\end{array}$ \\
\hline & 13aaa-1 & Conso 1 & 1979 & 540 & -- & -- & $\mathrm{Kmf}$ & 6,020 & $\mathrm{~F}$ & -- & $8-1-78$ & $\mathrm{c}$ & Plugged. C \\
\hline & 16 acd-s1 & R. Jensen & -- & -- & -- & -- & Kme & 6,280 & -- & $5 \mathrm{~F}$ & $7-24-79$ & $\mathrm{U}$ & C \\
\hline & $31 a b a-1$ & $\begin{array}{l}\text { Johnson Land and } \\
\text { Livestock Co. }\end{array}$ & 1977 & 3,340 & 6 & 339 & $\mathrm{Kmf}$ & 6,720 & +3 & $1 \mathrm{~F}$ & $8-31-78$ & (1) & $\begin{array}{l}\text { Converted petroleum test. On } \\
8-31-78 \text { obstruction in hole } \\
\text { at } 504 \text { ft. Ferron Sandstone } \\
\text { Member from } 1,535 \text { to } 2,235 \\
\mathrm{ft.} \text { C }\end{array}$ \\
\hline$(D-23-6)$ & $3 \mathrm{ddc}-1$ & BLM (EMRIA 5) & 1977 & 284 & - & -- & $\operatorname{Knf}$ & 6,580 & -- & -- & -- & $\mathrm{C}$ & $\begin{array}{l}\text { Plugged. Driller reported } \\
\text { hole was dry. }\end{array}$ \\
\hline & $4 b c b-1$ & USGS (No. 2-3) & 1978 & 440 & -- & -- & $\mathrm{Kmf}$ & 6,1802 & 288.99 & $<1 \mathrm{~A}$ & $11-30-78$ & $\mathrm{~T}$ & Plugged. C \\
\hline & $6 a c c-1$ & USGS (No. 2-1) & 1978 & 385 & -- & -- & $\mathrm{Kmf}$ & 6,040 & 18.6 & $23 \mathrm{~A}$ & $11-21-78$ & $\mathrm{~T}$ & $\begin{array}{l}\text { Plugged. Top of Ferron Sand- } \\
\text { stone Member at } 290 \mathrm{ft} \text {; } \\
\text { entire thickness not pene- } \\
\text { trated. C }\end{array}$ \\
\hline & & & & 720 & -- & $665 P$ & $\mathrm{Kmf}$ & & +122 & $4 \mathrm{~F}$ & $11-28-78$ & & A. $\mathrm{C}$ \\
\hline & 17 dba-S1 & BLM & -- & -- & -- & -- & $\mathrm{Kmf}$ & 5,830 & -- & $1 \mathrm{~F}$ & $11-8-78$ & $\mathrm{U}$ & $\mathrm{C}$ \\
\hline & $18 \mathrm{bac}-1$ & Hidden Valley Coal Co. & 1977 & 439 & 2.75 & 165 & $\mathrm{Km} f$ & 6,020 & FR & $17 \mathrm{FR}$ & $8-14-78$ & $\mathrm{U}$ & $\begin{array}{l}\text { Cement grout around casing } \\
\text { from surface to } 165 \mathrm{ft} .\end{array}$ \\
\hline
\end{tabular}


Table 5. Records of selected wells, test holes, and springs in the Castle Valley area-Continued

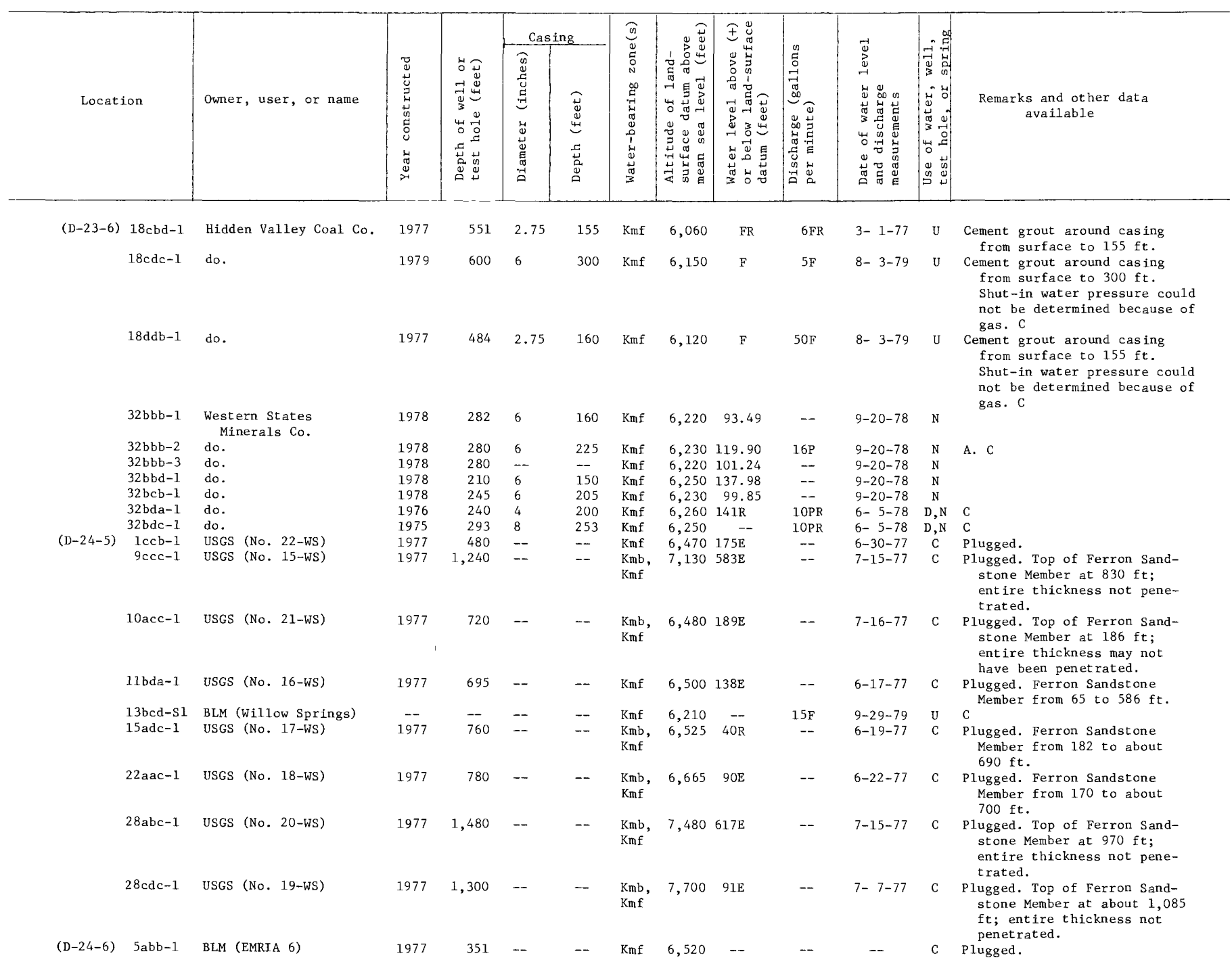




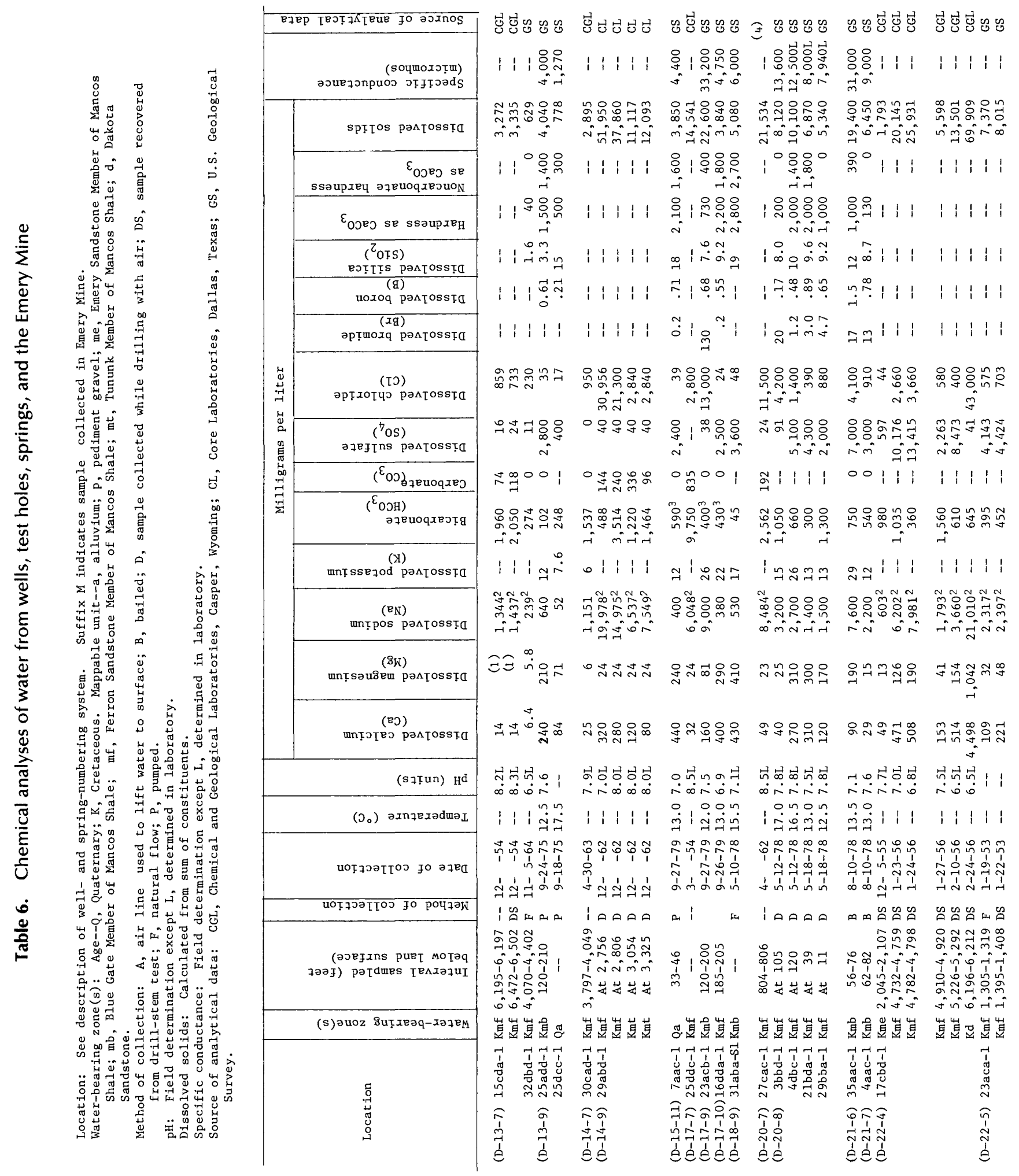




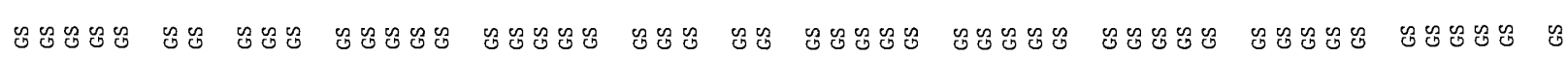

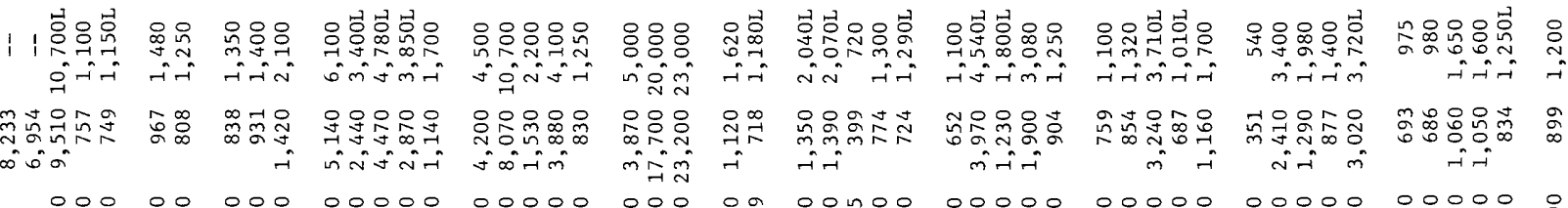

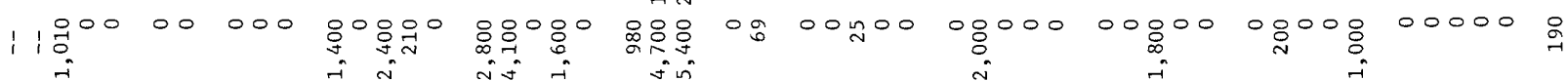

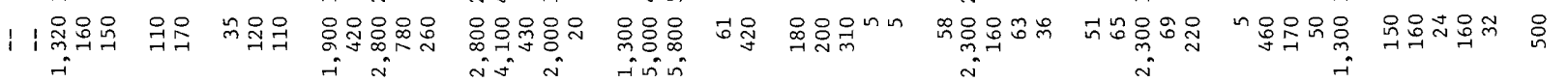
1 1 | 1

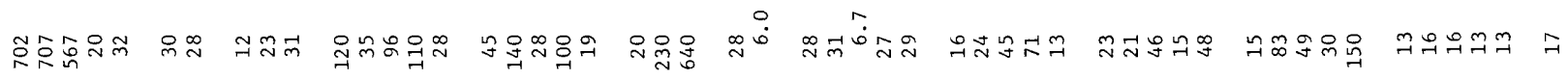

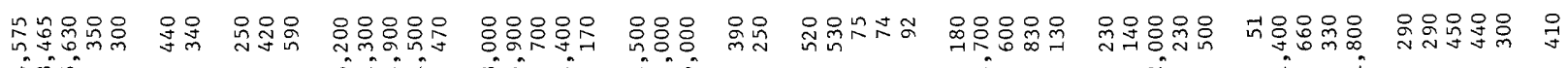
fmin

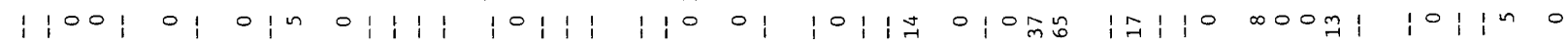

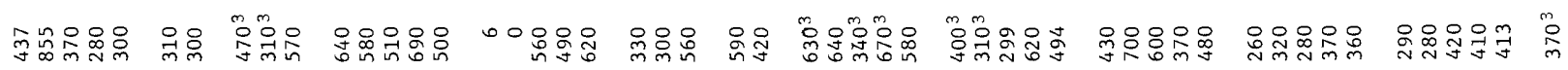
1 11 䓆

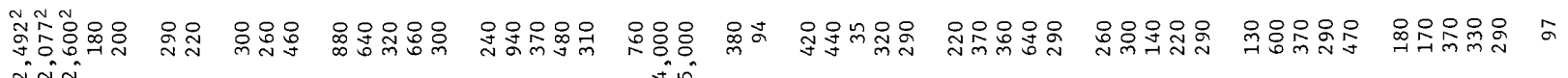

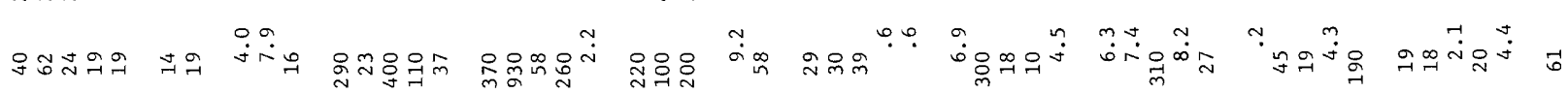

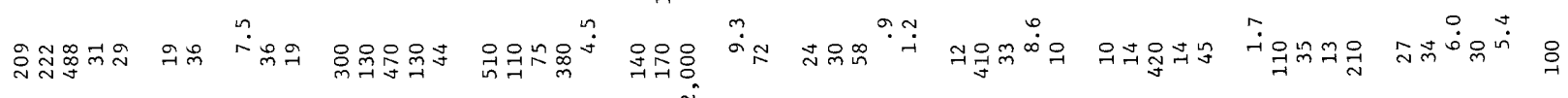

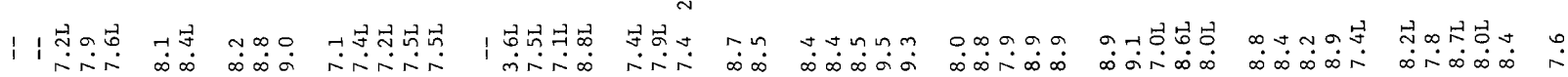

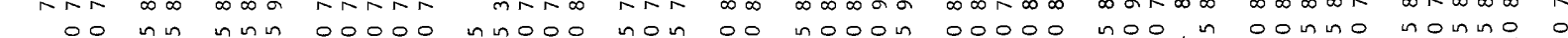

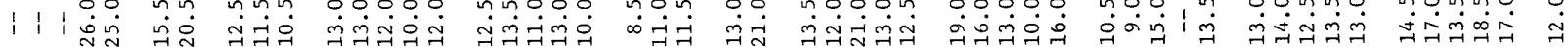

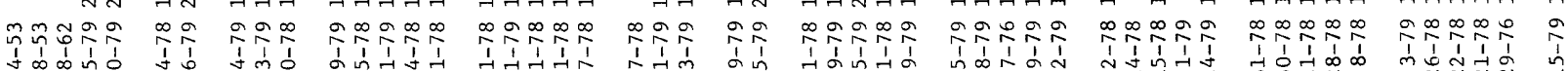

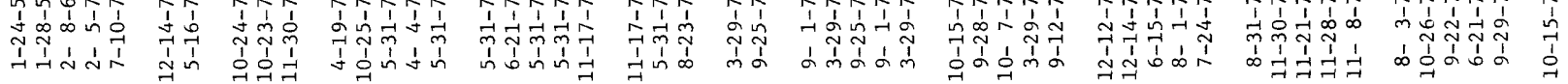

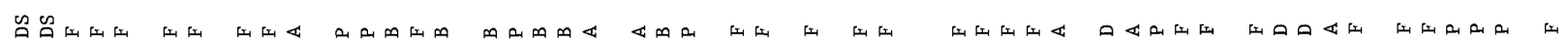

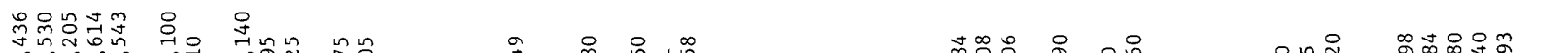

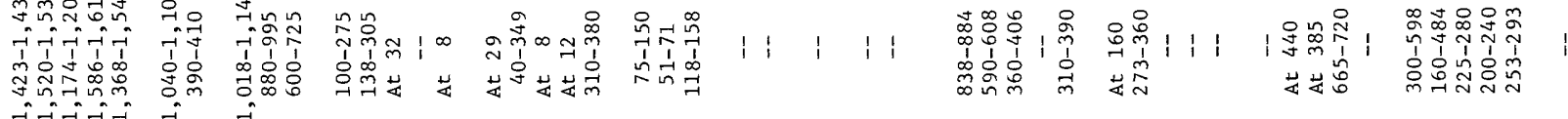

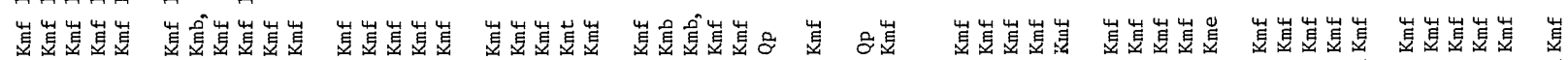

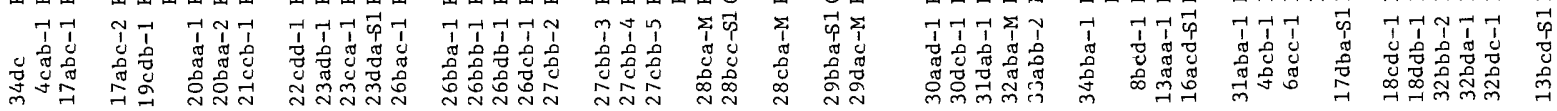

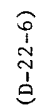

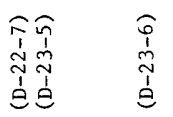




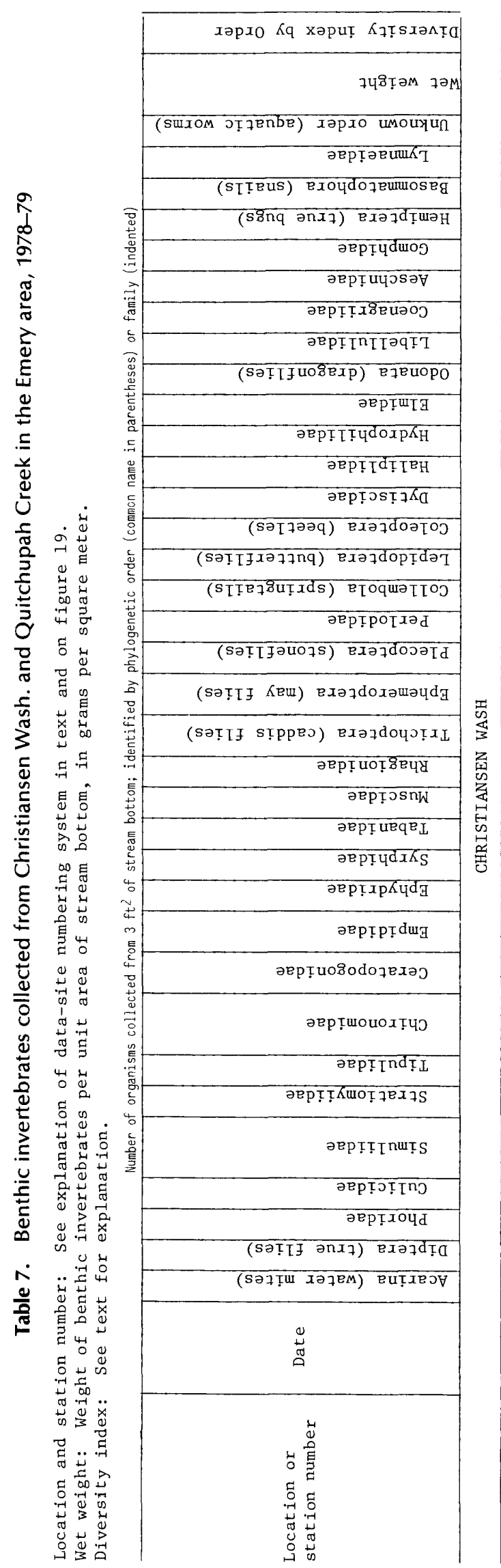

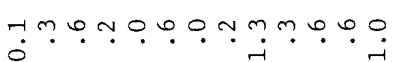

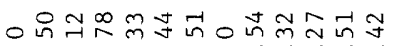

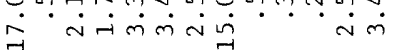

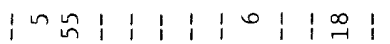

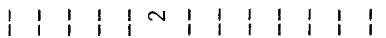
$\begin{array}{lllllllllllll}1 & 1 & 1 & 1 & 1 & 1 & 1 & 1 & 1 & 1 & 1 & 1 & 1\end{array}$ | | $\mid$\begin{tabular}{l|l|r|l|l|l|}
1 & -1 & 1
\end{tabular}

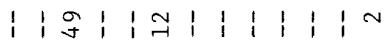
1 1 1 1 1 1 1 1 | $\begin{array}{lllllllllllll}1 & 1 & 1 & 1 & 1 & 1 & 1 & 1 & 1 & 1 & 1 & 1 & 1\end{array}$ $\begin{array}{lllllllllllll}1 & 1 & 1 & 1 & 1 & 1 & 1 & 1 & 1 & 1 & 1 & 1 & 1\end{array}$

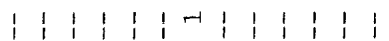

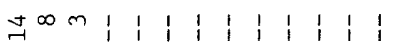
$\begin{array}{lllllllllllll}1 & 1 & -1 & 1 & 1 & 1 & 1 & 1 & 1 & 1 & 1 & 1 & 1\end{array}$

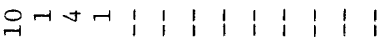
$\begin{array}{llllllllllll}1 & 1 & 1 & 1 & 1 & 1 & 1 & 1 & 1 & 1 & -1 & 1\end{array}$

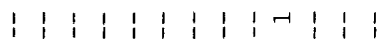

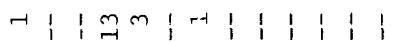
$\begin{array}{lllllllllllll}1 & 1 & 1 & 1 & 1 & 1 & 1 & 1 & 1 & 1 & 1 & 1 & 1\end{array}$ $\begin{array}{lllllllllllll}1 & 1 & 1 & 1 & 1 & 1 & 1 & 1 & 1 & 1 & 1 & 1 & 1\end{array}$

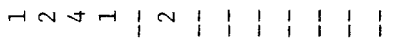
| 1 : $\begin{array}{lllllllllllll}1 & 1 & 1 & 1 & 1 & 1 & 1 & 1 & 1 & 1 & 1 & 1 & 1\end{array}$

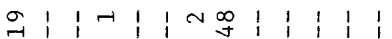

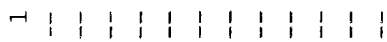

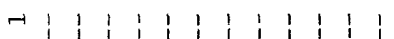

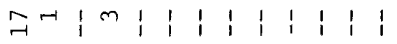
1 1 1 1 1 1 1 |

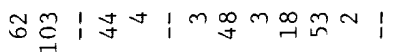

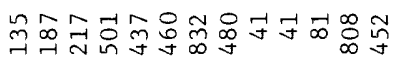
ก नं नी ! | $\infty \quad \begin{array}{lllllllll}1 & \rightarrow+ & 1 & 1 & 1 & 1 & 1 & 1\end{array}$

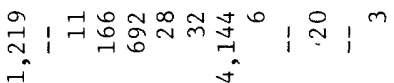

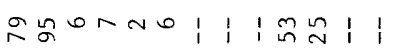

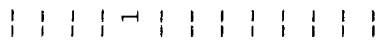
$\begin{array}{lllllllllllll}1 & 1 & 1 & 1 & 1 & 1 & 1 & 1 & 1 & 1 & 1 & 1 & 1\end{array}$ N 1 1 1 | måm

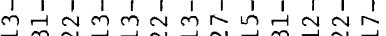

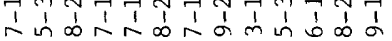

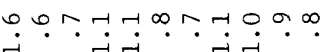
ㅎํㅇำำํำ $\dot{0} \cdot \dot{-} \cdot \dot{\sigma} \dot{-} \cdot$

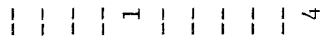
| | IÑ | $\begin{array}{lllllllllll}1 & 1 & 1 & 1 & 1 & 1 & 1 & 1 & 1 & 1 & 1\end{array}$ $\sim 1 \mid ⿰ 丿 \begin{array}{lllllll}1 & \infty & 1 & 1 & -1 & 1\end{array}$ $1|1| r \mid 1, \infty 111$ $\begin{array}{lllllllllll}1 & 1 & 1 & 1 & 1 & 1 & 1 & 1 & 1 & 1 & 1\end{array}$ 1111111011

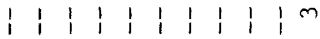

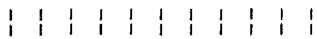

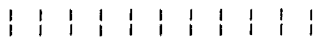

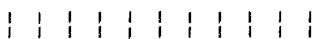
$\begin{array}{lllllllllll}1 & 1 & 1 & 1 & 1 & 1 & 1 & 1 & 1 & 1 & 1\end{array}$ $\begin{array}{lllllllllll}1 & 1 & 1 & 1 & 1 & 1 & 1 & 1 & 1 & 1 & 1\end{array}$

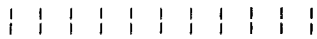
$\begin{array}{lllllllllll}1 & 1 & 1 & 1 & 1 & 1 & 1 & 1 & 1 & 1 & 1\end{array}$

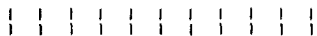
$\begin{array}{lllllllllll}1-1 & 1 & 1 & 1 & 1 & 1 & 1 & 1 & 1 & 1\end{array}$ $\begin{array}{lllllllllll}1 & 1 & 1 & 1 & 1 & 1 & 1 & 1 & -1 & 1 & 1\end{array}$ N 1 $1 \rightarrow 1$ i 1 |

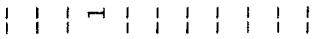
$1111-11111$ $\begin{array}{lllllllllll}1 & 1 & 1 & 1 & 1 & 1 & 1 & 1 & 1 & 1 & 1\end{array}$

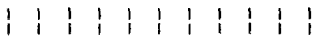

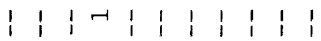
| 1 1 1 1 | 1유마

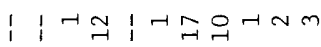
N

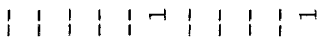

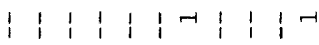
1||$^{m-1}|\sim| 1-$

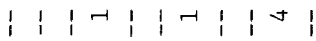
$\begin{array}{lllllllllll}1 & 1 & 1 & 1 & 1 & 1 & 1 & 1 & 1 & 1 & 1\end{array}$

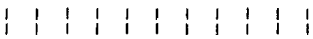
1 1 1 1 1 1 1 $211-$

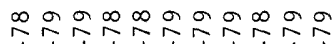

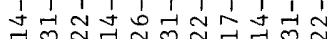

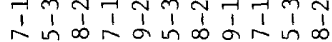
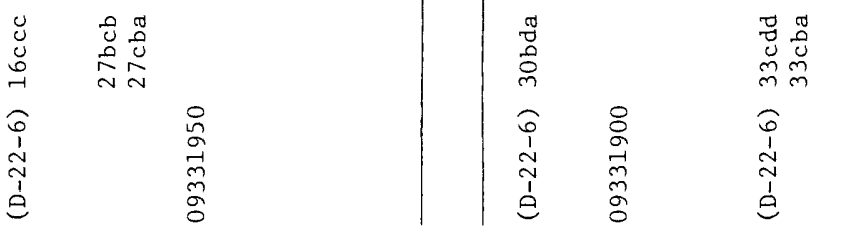